\title{
Mapping the Universe of Services Disciplines in Asian PTAs
}

\section{Rupa Chanda ${ }^{1}$}

\section{Abstract}

This paper analyses the relationship and dynamics between multilateral and regional or preferential trade rules and commitments in services in a sample of eight PTAs involving Asian countries. It examines the evolving universe of rules and negotiating architectures in services and the extent to which PTAs have gone beyond the GATS. (S-S) agreements. The analysis reveals that although countries tend to commit more sectors and subsectors under PTAs than under the GATS, these commitments are not deeper within subsectors or modes and that they tend to be less liberal than the existing policies. Where PTAs improve upon the GATS is in terms of their overall architecture as they include additional chapters and annexes which go into considerable detail on a variety of cross-cutting, sectorspecific, and emerging issues. The analysis suggests that North-North agreements tend to cover some of the more difficult issues such as government procurement, while North-South agreements have a focus on issues such as recognition of qualifications which relate to the importance of mode 4 in North-South services trade. South-South agreements tend to focus on institutional cooperation and establishment of mechanisms, reflecting the need for strengthening capacity and institution building in these countries. However, overall, there is considerable diversity among PTAs, which do not follow a uniform pattern, indicating that the negotiating dynamics vary by partner countries and across PTAs..

\section{${ }^{1}$ IIM Bangalore}

NCCR TRADE Working Papers are preliminary documents posted on the NCCR Trade Regulation website (<www.nccr-trade.org $>$ ) and widely circulated to stimulate discussion and critical comment. These papers have not been formally edited. Citations should refer to a "NCCR Trade Working Paper", with appropriate reference made to the author(s).

\section{IFN WNF}

FONDS NATIONAL SUISSE FONDO NAZIONALE SVIZZERO SWISS NATIONAL SCIENCE FOUNDATION
Die Nationalen Forschungsschwerpunkte (NFS) sind ein Förderinstrument des Schweizerischen Nationalfonds. Les Pôles de recherche nationaux (PRN) sont un instrument d'encouragement du Fonds national suisse. The National Centres of Competence in Research (NCCR) are a research instrument of the Swiss National Science Fondation. 


\title{
Mapping the Universe of Services Disciplines in Asian PTAs ${ }^{1}$
}

\author{
Rupa Chanda ${ }^{2}$ \\ IIM Bangalore
}

\section{Introduction}

In the past decade, there has been a surge in preferential trade agreements (PTAs) around the world. A notable development in this regard has been the trend towards more broad-based or comprehensive PTAs, which go beyond goods to include services, investment, and other "new age" issues such as government procurement, digital trade, and competition policy. There were 76 PTAs featuring provisions on trade and investment in services notified to the WTO in 2010, representing 28 per cent of all notified PTAs. Most were between developed and developing countries but a growing number are being conducted between developing countries. ${ }^{3}$

Asia has been an important participant in these trends. The region has witnessed an upswing in bilateral, regional, and cross-regional agreements. As of January 2010, 61 FTAs had been concluded in Asia, up from only 3 in 2000, with another 86 new agreements either under negotiation or proposed, thus clearly putting Asia at the forefront of PTA activity. ${ }^{4}$ Many of these PTAs have a services and investment component and involve important developed and developing countries in the region, including China, India, Japan, Korea, Singapore, the Philippines, and Thailand as well as important regional players such as ASEAN. ${ }^{5}$

The spate of Asian PTAs and, in particular, the widening of their ambit to areas such as services and investment can be attributed to several factors. These include the slow pace of negotiations under the Doha Development Round and the failure to achieve substantive progress in the new areas; the pursuit of broad-based PTAs by the EU and the US in turn leading the Asian countries to pursue preferential market access under similar agreements; and the perceived need to deepen integration through liberalization of investment, labour, and regulatory cooperation to support regional and bilateral production networks. The inclusion of services and investment issues reflects the increased policy interest in the service sector, growing recognition of the role played by services in economic development, and the importance of

\footnotetext{
${ }^{1}$ In this paper, the term PTAs is used to describe all types of agreements, including free trade agreements, economic partnership agreements, and comprehensive economic cooperation agreements.

${ }^{2}$ The author wishes to thank Pralok Gupta, doctoral student at IIM Bangalore for his research assistance and help in finalizing all the data tables and compiling information on the status of PTAs and unilateral policies. The author is also grateful to Shahana Mukherjee and Josmy Joseph for their enumeration of commitments in the General Agreement on Trade in Services (GATS) and in PTAs.

${ }^{3}$ Sauvé and Mattoo (2010), p.6.

${ }^{4}$ Wignaraja and Lazaro (2010).

${ }^{5}$ See, Fink and Molinuevo, 2007 for Asia and Martin, Marchetti, and Lim (2007) for advances in specific sectors.
} 
dismantling services trade and investment barriers. These trends also reflect the growing use of broader PTAs in Asia as a policy tool for addressing longer term objectives such as trade and investment facilitation, strategic diversification of trade flows, enhancing negotiating and regulatory capacity, and for providing impetus to unilateral liberalization.

There has been much analysis of the trade-creating and trade-diverting effects of PTAs in goods and how PTAs compare to most-favoured nation (MFN) based market access commitments and trade rules under the World Trade Organization (WTO). In contrast, comparatively little analysis has been undertaken of PTAs in services, mainly owing to the empirical challenges involved in assessing MFN or preferential trade flows in services. However, given the growing number of PTAs involving services and this being the likely trend for the future, an understanding of the relationship and dynamics between multilateral and regional or preferential trade rules and commitments in services (and related cross-cutting areas) is required. Such an analysis is needed given the significance of regulatory barriers in shaping services trade flows and thus the role of regulatory disciplines in governing services trade. Such analysis is also required given the incipient nature of many GATS disciplines and the rather low levels of binding GATS commitments and offers and thus the possibilities for cross-learning between the multilateral and the preferential trading system with regard to rule making, negotiating modalities and templates, and the scope for deepening and widening commitments in services on a preferential or multilateral basis. Such analysis would enable one to understand whether and to what extent PTAs complement, undermine, compete with, or aid multilateral negotiations in services.

\subsection{Scope and objectives}

The present paper attempts to fill this gap in the existing literature on services trade. It builds on the methodology used in a few earlier papers ${ }^{6}$ and analyses eight Asian PTAs: 7 intraregional and one crossregional; 7 bilateral and 1 regional; 7 concluded and 1 under negotiation; and involving a mix of developed and developing countries under North-North $(\mathrm{N}-\mathrm{N})$, North-South $(\mathrm{N}-\mathrm{S})$, and South-South $(\mathrm{S}-\mathrm{S})$ agreements. The selected agreements include the India-Korea CEPA (N-S), India-Singapore CECA (N-S), Japan-Singapore CECA (N-N), Japan-Philippines EPA (N-S), China-Pakistan FTA (SS), China-ASEAN FTA (regional, S-S), India-Sri Lanka CEPA (S-S), and the US-Korea FTA (crossregional, $\mathrm{N}-\mathrm{N}$ ).

The selection of these PTAs reflects several considerations. The most important reason underlying their selection was the need to include agreements which involved different combinations of partners in terms of income levels, i.e., a mix of North-North, North-South, and South-South agreements, as noted above. The second consideration was to include at least one regional PTA along with the usual bilateral PTAs. Hence, China-ASEAN was chosen as a PTA involving a regional bloc with another country within Asia. A third consideration was the need to include at least one extra-regional PTA, as captured by the USKorea FTA. A final consideration was the need to include agreements at different stages of completion, some concluded and already in force (recent or earlier), and some still under negotiation. The US-Korea and India-Sri Lanka CEPA were chosen to cover PTAs where there are no commitments as yet but where a detailed framework is available for comparison with the GATS, while under the other PTAs, there is scope to discuss the commitments made vis-à-vis those under the GATS. 
The analysis of the selected PTAs focuses on three aspects. These relate to:

(1) their negotiating architecture and scheduling modalities;

(2) their overall framework of disciplines and chapters on cross-cutting issues and;

(3) the scope and depth of commitments made under these PTAs compared to those undertaken by these same countries under the GATS.

The wider objective of this analysis is to gain a better understanding of the evolving universe of rules and negotiating architectures in services and the extent to which PTAs have gone beyond the GATS in rule making and commitments and thus might provide scope to adopt best practices for future WTO negotiations. For this purpose, the comparative analysis specifically addresses several questions. How equivalent are PTA provisions to those found in the GATS? Do the PTA rules promote "open regionalism" and to what extent are they discriminatory towards non-member countries? Do the PTAs involve advances in rule making relative to the GATS and if so, in what manner? What differing approaches and negotiating architectures are used in these PTAs compared to those under the GATS? Where do the PTAs fall short with regard to rule making or market access commitments? Are these similar to those found under the GATS? What differences and similarities emerge relative to the GATS with respect to concerns in specific sectors and on specific issues? And to what extent and in what manner do the PTAs enable countries to evolve more pro-competitive regulations and to build negotiating and regulatory capacity which could be useful for the multilateral services negotiations? In examining these issues, an attempt is made to identify commonalities and differences between these selected PTAs and the GATS and also to identify patterns with regard to the scope and depth of commitments and of rule making with respect to the nature of the countries (developed or developing) involved in the PTAs.

\section{$1.2 \quad$ Outline}

Following this introduction, Section 2 of the paper provides an overview of the status of services PTAs in Asia, including those discussed in this paper. Section 3 provides an analysis of the architecture of the selected agreements, in terms of the negotiating approach, carve-outs, and generally applicable or excluded measures for the selected agreements. Section 4 discusses the overall framework of these PTAs vis-à-vis the GATS and examines key disciplines and specific chapters on cross-cutting issues such as movement of natural persons and investment to identify similarities and differences between the multilateral and preferential frameworks and their implications. Section 5 discusses the scope and coverage of commitments, by sectors and by modes under the PTAs, both quantitatively and qualitatively, in comparison with the Uruguay Round commitments and latest GATS offers made by these same countries and what this implies about the countries' preferential versus multilateral negotiating stance and preparedness. Section 6 briefly examines how the PTA commitments relate to unilateral liberalization undertaken in selected services for mode 3 (investment) in some of the countries concerned and what this reveals about the dynamic between unilateral, preferential, and multilateral liberalization. The final section concludes the paper by summarizing the main take home messages from this analysis and by identifying what PTAs have to offer for global rule making and services negotiations.

\section{Status of PTAs in services in Asia}


The rise of services PTAs in Asia is a recent phenomenon. Until 2000, the only trade agreement in services in Asia was the ASEAN Framework Agreement on Trade in Services or AFAS. However, since then over 30 agreements - of which at least one Asian country is a member - covering services, have been signed or are at different stage of negotiation. Table 1 provides the latest situation with regard to participation by Asian countries in FTAs, both service and non-services agreements, in 2010.

Table $1 \quad$ FTA status in Asia as of July 2010

\begin{tabular}{|l|c|c|c|c|c|c|}
\hline \multirow{2}{*}{ Country } & & \multicolumn{2}{c|}{ Under Negotiation } & \multicolumn{2}{c|}{ Concluded } & \multirow{2}{*}{ Total } \\
\cline { 2 - 6 } & Proposed & $\begin{array}{c}\text { Framework } \\
\text { Agreement } \\
\text { Signed/Under } \\
\text { Negotiation }\end{array}$ & $\begin{array}{c}\text { Under } \\
\text { Negotiation }\end{array}$ & Signed & In Effect & \\
\hline Afghanistan & 1 & 0 & 0 & 1 & 2 & 4 \\
\hline Armenia & 0 & 0 & 0 & 2 & 7 & 9 \\
\hline Australia & 6 & 2 & 5 & 0 & 8 & 21 \\
\hline Azerbaijan & 0 & 0 & 0 & 6 & 3 & 9 \\
\hline Bangladesh & 0 & 2 & 1 & 1 & 2 & 6 \\
\hline Bhutan & 0 & 1 & 0 & 0 & 2 & 3 \\
\hline Brunei Darussalam & 4 & 1 & 1 & 0 & 8 & 14 \\
\hline Cambodia & 2 & 0 & 1 & 0 & 6 & 9 \\
\hline China, People's & 8 & 3 & 3 & 1 & 10 & 25 \\
\hline Republic of & 1 & 0 & 1 & 0 & 2 & 4 \\
\hline Cook Islands & 1 & 0 & 1 & 0 & 3 & 5 \\
\hline Fiji Islands & 0 & 0 & 0 & 2 & 8 & 10 \\
\hline Georgia & 1 & 1 & 0 & 1 & 1 & 4 \\
\hline Hong Kong, China & 11 & 4 & 7 & 0 & 11 & 33 \\
\hline India & 7 & 1 & 1 & 1 & 7 & 17 \\
\hline Indonesia & 6 & 0 & 5 & 0 & 11 & 22 \\
\hline Japan & 2 & 1 & 0 & 3 & 5 & 11 \\
\hline Kazakhstan & 1 & 0 & 1 & 0 & 2 & 4 \\
\hline Kiribati & 10 & 2 & 8 & 1 & 6 & 27 \\
\hline Korea, Republic of & 2 & 0 & 0 & 2 & 7 & 10 \\
\hline Kyrgyz Republic & 1 & 1 & 1 & 0 & 8 & 11 \\
\hline Lao PDR & & 0 & 2 & 8 & 19 \\
\hline Malaysia & & & & & \\
\hline
\end{tabular}




\begin{tabular}{|l|c|c|c|c|c|c|}
\hline Maldives & 1 & 0 & 0 & 0 & 1 & 2 \\
\hline Marshall Islands & 1 & 0 & 1 & 0 & 2 & 4 \\
\hline $\begin{array}{l}\text { Micronesia, } \\
\text { Federated States of }\end{array}$ & 1 & 0 & 1 & 0 & 2 & 4 \\
\hline Mongolia & 1 & 0 & 0 & 0 & 0 & 1 \\
\hline Myanmar & 2 & 1 & 1 & 0 & 6 & 10 \\
\hline Nauru & 1 & 0 & 1 & 0 & 2 & 4 \\
\hline Nepal & 1 & 1 & 0 & 0 & 2 & 4 \\
\hline New Zealand & 4 & 1 & 3 & 2 & 7 & 17 \\
\hline Pakistan & 10 & 5 & 3 & 2 & 6 & 26 \\
\hline Palau & 1 & 0 & 1 & 0 & 2 & 4 \\
\hline Papua New Guinea & 1 & 0 & 1 & 0 & 4 & 6 \\
\hline Philippines & 4 & 0 & 1 & 0 & 7 & 12 \\
\hline Samoa & 1 & 0 & 1 & 0 & 2 & 4 \\
\hline Singapore & 4 & 1 & 9 & 3 & 18 & 35 \\
\hline Solomon Islands & 1 & 0 & 1 & 0 & 3 & 5 \\
\hline Sri Lanka & 2 & 1 & 0 & 1 & 4 & 8 \\
\hline Taipei,China & 1 & 2 & 1 & 0 & 4 & 8 \\
\hline Tajikistan & 2 & 0 & 0 & 7 & 2 & 11 \\
\hline Thailand & 6 & 4 & 3 & 0 & 11 & 24 \\
\hline Tonga & 1 & 0 & 1 & 0 & 2 & 4 \\
\hline Turkmenistan & 0 & 0 & 0 & 1 & 2 & 3 \\
\hline Tuvalu & 1 & 0 & 1 & 0 & 2 & 4 \\
\hline Uzbekistan & 1 & 0 & 0 & 7 & 3 & 11 \\
\hline Vanuatu & 1 & 0 & 1 & 0 & 3 & 5 \\
\hline Viet Nam & 3 & 1 & 2 & 0 & 7 & 13 \\
\hline Source: & & & & &
\end{tabular}

Source: $\underline{\text { http://www.aric.adb.org/10.php }}$

It is evident from Table 1 that all the key countries in south, south east and east Asia, including China, India, Japan, the Republic of Korea, and Singapore, have entered into a large number of FTAs. It is also interesting to observe that the spurt in PTAs in the Asian region occurred from around 2003-2005. Appendix Tables A1.1 to A1.11 provide a chronology of the PTAs signed by selected Asian countries and further highlight how, in recent years, the lag between the signing and entry into force of PTAs has reduced in the region. The reduction in the time lag is perhaps indicative of the learning process involved in the negotiation and implementation of PTAs.

There has also been a trend towards "broad-basing" agreements by including areas such as services and investment. Table 2 illustrates the share of PTAs which cover services for selected Asian countries. It is evident that for the most advanced countries in the region, namely, Japan, the Republic of Korea, and Singapore, more than $90 \%$ of the PTAs cover services. For almost all the selected countries, over half of the PTAs cover services. This includes all the major developing countries in Asia, such as China, India, and the ASEAN countries. It is thus apparent that services are an increasingly important area of negotiating interest not only for the advanced Asian countries but also for the emerging economies in Asia. 
Table 2 PTAs featuring services for selected Asian countries, July 2010

\begin{tabular}{|l|r|r|r|}
\hline \multicolumn{1}{|c|}{ Country } & \multicolumn{1}{c|}{$\begin{array}{c}\text { Total No. of } \\
\text { PTAs }\end{array}$} & $\begin{array}{l}\text { Total No. of PTAs Featuring } \\
\text { Services Provisions }\end{array}$ & $\begin{array}{c}\text { Services Provisions PTAs as a } \\
\text { Percentage of Total No. of } \\
\text { PTAs }\end{array}$ \\
\hline Bangladesh & 5 & 3 & 60 \\
\hline Cambodia & 8 & 7 & 88 \\
\hline China & 20 & 19 & 95 \\
\hline Hong Kong & 3 & 3 & 100 \\
\hline India & 23 & 14 & 61 \\
\hline Indonesia & 13 & 11 & 85 \\
\hline Japan & 18 & 18 & 100 \\
\hline Korea, & 14 & 14 & 100 \\
Republic of & 18 & 14 & 78 \\
\hline Malaysia & 10 & 3 & 30 \\
\hline Pakistan & 10 & 9 & 90 \\
\hline Philippines & 24 & 22 & 60 \\
\hline Singapore & 5 & 3 & 76 \\
\hline Sri Lanka & 17 & 13 & \\
\hline Thailand & & & \\
\hline
\end{tabular}

Source: http://www.aric.adb.org/10.php

Note: The number of FTAs for each country may not exactly match the figures provided in Table 1 owing to slight differences in the treatment of agreements which are under negotiation. However, the overall numbers are broadly similar.

The status of the 8 PTAs selected for discussion in this paper is highlighted in Table 3. These are all PTAs that have been signed since 2000, particularly in the last 5-6 years. Most have come into effect very recently.

Table 3 Status of selected Asian PTAs

\begin{tabular}{|l|c|c|c|c|c|c|c|}
\hline \multirow{2}{*}{ FTA Name } & \multirow{2}{*}{$\begin{array}{c}\text { Under } \\
\text { Negotiation }\end{array}$} & Signed & \multirow{2}{*}{$\begin{array}{c}\text { In } \\
\text { effect }\end{array}$} & $\begin{array}{c}\text { Notified } \\
\text { to the } \\
\text { WTO }\end{array}$ & & & \multicolumn{3}{c|}{ Negotiation } & Signed & $\begin{array}{c}\text { In } \\
\text { effect }\end{array}$ \\
\hline India-Korea CEPA & & $\sqrt{ }$ & $\sqrt{ }$ & $\sqrt{ }$ & & 2009 & 2010 \\
\hline India-Singapore CECA & & $\sqrt{ }$ & $\sqrt{ }$ & $\sqrt{ }$ & & 2005 & 2005 \\
\hline $\begin{array}{l}\text { Japan-Singapore } \\
\text { CECA }\end{array}$ & & $\sqrt{ }$ & $\sqrt{ }$ & $\sqrt{ }$ & & 2002 & 2002 \\
\hline Japan-Philippines EPA & & $\sqrt{n}$ & $\sqrt{ }$ & $\sqrt{ }$ & & 2006 & 2008 \\
\hline China-Pakistan FTA & & $\sqrt{ }$ & $\sqrt{ }$ & $\sqrt{ }$ & & 2009 & 2009 \\
\hline China-ASEAN FTA & & $\sqrt{ }$ & $\sqrt{ }$ & $\sqrt{ }$ & & 2004 & 2005 \\
\hline India-Sri Lanka CEPA & $\sqrt{ }$ & & & & 2005 & & \\
\hline
\end{tabular}


US-Korea FTA

Source: http://www.aric.adb.org/10.php

The following sections examine the frameworks as well as the scope and depth of commitments undertaken in those of the above PTAs which are now in effect to assess how much further preferential agreements have gone relative to the GATS in terms of their architecture and in terms of enabling services liberalization.

\section{Coverage of disciplines and cross-cutting issues in selected Asian PTAs}

One of the most important areas to examine is the overall framework of rules and provisions under the PTAs covering services and the extent to which there is convergence or divergence from the coverage of similar rules and disciplines under the GATS. The following discussion takes a step by step approach to examining these similarities and differences among the PTAs and between the PTAs and the GATS.

The first part examines key disciplines under the GATS and whether these are covered under the selected PTAs and also the manner in which they are covered. This analysis is used to draw some broad inferences about the approaches and the possible underlying reasons for the approaches adopted. It also tries to identify patterns based on the typology of these PTAs in terms of the countries involved. The second part of this discussion provides an overview of the coverage of chapters and annexes on cross-cutting issues which have a bearing on services trade, in the selected PTAs. The analysis again tries to identify some patterns in the scope of these chapters and annexes in terms of the typology of the PTAs and the countries involved. The final part of this section highlights the carve-outs in each of the selected PTAs and outlines the similarities and differences among the agreements and also in relation to the GATS.

The overall objective of this section is to highlight, through comparisons with the GATS, whether PTAs in services have made possible more comprehensive rule making than under the GATS, and to what extent they may have used the GATS as a benchmark for rule making. By providing comparisons among the PTAs on each of these issues, the aim is to highlight how levels of development, differences in bargaining power and asymmetries in size, among others might influence the approach to services liberalization under PTAs.

\subsection{Key disciplines: Some general insights}

An examination of the 8 PTAs selected for this study reveals that although they differ in terms of the nature of the countries involved (and as will be seen later also in terms of the scope and depth of scheduled commitments), they are broadly similar to each other and to the GATS with regard to the framework of rules and provisions. Table 4 summarizes the coverage of all major disciplines and provisions in the services chapters of the selected PTAs.

Table 4 Coverage of key disciplines in services chapters of selected PTAs

\begin{tabular}{|l|l|l|l|l|l|l|l|l|}
\hline \multirow{3}{*}{ Disciplines } & \multicolumn{3}{|c|}{ North-South PTAs } & \multicolumn{3}{c|}{ South-South PTAs } & \multicolumn{2}{c|}{ North-North PTAs } \\
\cline { 2 - 7 } & $\begin{array}{l}\text { India- } \\
\text { Singapore }\end{array}$ & $\begin{array}{l}\text { India- } \\
\text { Korea }\end{array}$ & $\begin{array}{l}\text { Japan- } \\
\text { Philippines }\end{array}$ & $\begin{array}{l}\text { India-Sri } \\
\text { Lanka }\end{array}$ & $\begin{array}{l}\text { China- } \\
\text { ASEAN FTA }\end{array}$ & $\begin{array}{l}\text { China- } \\
\text { Pakistan }\end{array}$ & $\begin{array}{l}\text { Japan- } \\
\text { Singapore }\end{array}$ & $\begin{array}{l}\text { US-Korea } \\
\text { FTA }\end{array}$ \\
\hline
\end{tabular}




\begin{tabular}{|c|c|c|c|c|c|c|c|c|}
\hline & CECA & CEPA & $E P A$ & CEPA & & FTA & CECA & \\
\hline MFN & $\mathrm{X}$ & $\mathrm{X}$ & $\mathrm{X}$ & $\mathrm{X}$ & No & No & No & $\mathrm{X}$ \\
\hline $\begin{array}{l}\text { National } \\
\text { treatment }\end{array}$ & $\mathrm{X}$ & $\mathrm{X}$ & $\mathrm{X}$ & $\mathrm{X}$ & $\mathrm{X}$ & $\mathrm{X}$ & $\mathrm{X}$ & $\mathrm{X}$ \\
\hline Transparency & $\mathrm{X}$ & $\mathrm{X}$ & $\mathrm{X}$ & $\mathrm{X}$ & $\mathrm{X}$ & $\mathrm{X}$ & No & $\mathrm{X}$ \\
\hline $\begin{array}{l}\text { Market access } \\
\text { non- } \\
\text { discriminatory }\end{array}$ & $\mathrm{X}$ & $\mathrm{X}$ & $\mathrm{X}$ & $\mathrm{X}$ & $\mathrm{X}$ & $\mathrm{X}$ & $\mathrm{X}$ & $\mathrm{X}$ \\
\hline $\begin{array}{l}\text { Domestic } \\
\text { regulation }\end{array}$ & $\mathrm{X}$ & $\mathrm{X}$ & $\begin{array}{l}\mathrm{X} \\
\text { (Authorization, } \\
\text { licensing, } \\
\text { qualification) }\end{array}$ & $\mathrm{X}$ & $\mathrm{X}$ & $\mathrm{X}$ & $\mathrm{X}$ & $\begin{array}{l}\mathrm{X} \\
\text { (specific to } \\
\text { development } \\
\text { and } \\
\text { application } \\
\text { of domestic } \\
\text { regulation) }\end{array}$ \\
\hline $\begin{array}{l}\text { Safeguard } \\
\text { measures }\end{array}$ & $\mathrm{X}$ & $\mathrm{X}$ & $\begin{array}{l}\text { No } \\
\text { (included in } \\
\text { investment } \\
\text { chapter) }\end{array}$ & $\mathrm{X}$ & $\mathrm{X}$ & $\mathrm{X}$ & $\begin{array}{l}\text { No (included } \\
\text { in } \\
\text { investment } \\
\text { chapter) }\end{array}$ & No \\
\hline Recognition & $\mathrm{X}$ & $\mathrm{X}$ & $\mathrm{X}$ & $\mathrm{X}$ & $\mathrm{X}$ & $\mathrm{X}$ & $\begin{array}{l}\text { No (separate } \\
\text { chapter on } \\
\text { MNP where } \\
\text { mutual } \\
\text { recognition } \\
\text { is covered) }\end{array}$ & $\mathrm{X}$ \\
\hline Subsidies & $\mathrm{X}$ & $\mathrm{X}$ & No & $\mathrm{X}$ & $\mathrm{X}$ & No & No & No \\
\hline $\begin{array}{l}\text { Government } \\
\text { procurement }\end{array}$ & $\mathrm{X}$ & No & $\begin{array}{l}\text { No (separate } \\
\text { chapter) }\end{array}$ & $\mathrm{X}$ & No & No & $\begin{array}{l}\text { No (separate } \\
\text { chapter) }\end{array}$ & $\begin{array}{l}\text { No (separate } \\
\text { chapter) }\end{array}$ \\
\hline $\begin{array}{l}\text { Monopolies } \\
\text { and exclusive } \\
\text { suppliers }\end{array}$ & $\mathrm{X}$ & $\mathrm{X}$ & $\mathrm{X}$ & $\mathrm{X}$ & $\mathrm{X}$ & $\mathrm{X}$ & $\mathrm{X}$ & No \\
\hline $\begin{array}{l}\text { Business } \\
\text { practices }\end{array}$ & $\mathrm{X}$ & $\mathrm{X}$ & No & $\mathrm{X}$ & $\mathrm{X}$ & $\mathrm{X}$ & $\mathrm{X}$ & No \\
\hline $\begin{array}{l}\text { Payments and } \\
\text { transfers }\end{array}$ & $\mathrm{X}$ & $\mathrm{X}$ & $\mathrm{X}$ & $\mathrm{X}$ & $\mathrm{X}$ & $\mathrm{X}$ & $\mathrm{X}$ & $\mathrm{X}$ \\
\hline $\begin{array}{l}\text { General } \\
\text { exceptions }\end{array}$ & $\mathrm{X}$ & $\mathrm{X}$ & $\mathrm{X}$ & $\mathrm{X}$ & $\mathrm{X}$ & $\mathrm{X}$ & $\mathrm{X}$ & $\mathrm{X}$ \\
\hline $\begin{array}{l}\text { Rule of origin } \\
\text { (denial of } \\
\text { benefit) }\end{array}$ & $\mathrm{X}$ & $\mathrm{X}$ & $\mathrm{X}$ & $\mathrm{X}$ & $\mathrm{X}$ & $\mathrm{X}$ & $\mathrm{X}$ & $\mathrm{X}$ \\
\hline
\end{tabular}




\begin{tabular}{|c|c|c|c|c|c|c|c|c|}
\hline $\begin{array}{l}\text { Restrictions } \\
\text { to safeguard } \\
\text { the balance of } \\
\text { payments }\end{array}$ & $\mathrm{X}$ & $\mathrm{X}$ & $\mathrm{X}$ & $\mathrm{X}$ & $\mathrm{X}$ & $\mathrm{X}$ & $X$ & $\mathrm{X}$ \\
\hline $\begin{array}{l}\text { Dispute } \\
\text { settlement }\end{array}$ & $\begin{array}{l}\text { No } \\
\text { (separate } \\
\text { chapter and } \\
\text { included in } \\
\text { investment } \\
\text { chapter) }\end{array}$ & $\begin{array}{l}\text { No } \\
\text { (separate } \\
\text { chapter } \\
\text { and } \\
\text { included } \\
\text { in } \\
\text { investment } \\
\text { chapter) }\end{array}$ & $\begin{array}{l}\text { No } \\
\text { (separate } \\
\text { chapter) }\end{array}$ & $\begin{array}{l}\text { No } \\
\text { (separate } \\
\text { chapter } \\
\text { and } \\
\text { included } \\
\text { in } \\
\text { investment } \\
\text { chapter) }\end{array}$ & $\begin{array}{l}\mathrm{X} \\
\text { (reference to } \\
\text { separate } \\
\text { chapter on } \\
\text { dispute } \\
\text { settlement) }\end{array}$ & $\mathrm{X}$ & $\begin{array}{l}\text { No } \\
\text { (separate } \\
\text { chapter and } \\
\text { included in } \\
\text { investment } \\
\text { chapter) }\end{array}$ & $\begin{array}{l}\text { No } \\
\text { (separate } \\
\text { chapter and } \\
\text { included in } \\
\text { investment } \\
\text { chapter with } \\
\text { additional } \\
\text { annexes on } \\
\text { specific } \\
\text { issues) }\end{array}$ \\
\hline $\begin{array}{l}\text { Selected } \\
\text { additional } \\
\text { provisions } \\
\text { not found in } \\
\text { GATS }\end{array}$ & $\begin{array}{l}\text { Services- } \\
\text { investment } \\
\text { linkage }\end{array}$ & $\begin{array}{l}\text { Services- } \\
\text { investment } \\
\text { linkage }\end{array}$ & $\begin{array}{l}\text { Sub-committee } \\
\text { on trade in } \\
\text { services }\end{array}$ & $\begin{array}{l}\text { Services- } \\
\text { investment } \\
\text { linkage, } \\
\text { sub- } \\
\text { committee } \\
\text { on trade in } \\
\text { services }\end{array}$ & $\begin{array}{l}\text { Cooperation } \\
\text { (for } \\
\text { enhancing } \\
\text { capacity and } \\
\text { efficiency) } \\
\text { Different } \\
\text { levels of } \\
\text { government }\end{array}$ & $\begin{array}{l}\text { Cooperation } \\
\text { (for } \\
\text { enhancing } \\
\text { capacity and } \\
\text { efficiency), } \\
\text { Committee on } \\
\text { Trade in } \\
\text { Services }\end{array}$ & $\begin{array}{l}\text { Service } \\
\text { suppliers of } \\
\text { any non- } \\
\text { party }\end{array}$ & $\begin{array}{l}\text { Non- } \\
\text { conforming } \\
\text { measures, } \\
\text { local } \\
\text { presence }\end{array}$ \\
\hline
\end{tabular}

Source: Based on an analysis of the legal texts of the selected PTAs

As shown in Table 4, the disciplines that are present in the services chapter for all 8 of the selected PTAs and which are also closest in wording and intent to that found under the GATS are the disciplines on market access and national treatment, which form the basic pillars of the GATS liberalization architecture. In addition, general rules and obligations which are common across the selected PTAs and which are again quite similar in scope and intent to that found in the GATs are those on transparency, domestic regulation, payments and transfers, restrictions to safeguard the balance of payments, general exceptions, and rule of origin (denial of benefits). These latter disciplines involve broadly similar terms and conditions across all the PTAs, and the wording is also very similar, in several cases, exactly the same as that employed under the GATS. Several of the PTAs specifically refer to the pertinent article under the GATS for further definitions and clarifications, clearly indicating that the GATS has been used as a benchmark for establishing the framework of these preferential services agreements. Therefore, the PTAs do not deviate much from the GATS or from one another in terms of the basic liberalization framework they follow, which is defined by the market access and national treatment obligations. They also do not deviate much with regard to coverage of key issues such as domestic regulation which indicates recognition of the latter as the key impediment to services trade and investment and the importance of including obligations such as objectivity and transparency in applying domestic regulations and not nullifying the services commitments made.

A slightly different approach is evident in the case of some other disciplines such as those on monopolies and exclusive suppliers, transparency, business practices, and recognition which may not always be present in the services chapter but may be included in other relevant chapters. Of the selected PTAs, at least 6 contain such provisions, but even when these provisions are not found in the services chapter, they 
are present elsewhere in the PTA. For instance, although the provision on business practices is not included in the services chapter of the Japan-Philippines Economic Partnership Agreement (JPEPA), the intent of this provision is captured in provisions under a different chapter entitled Business Environment in the JPEPA text. Likewise, although recognition is not explicitly covered in the services chapter of the Japan-Singapore agreement, there is a provision on recognition under the chapter on movement of natural persons, with wording similar to that found under the GATS or other PTAs for disciplines on mutual recognition. It is worth noting that even when some of these provisions, such as those on recognition, are included in the services chapter they may also be present in other chapters, signifying their overall importance. This approach to the coverage of key disciplines suggests that some provisions have been included where they have a more direct bearing on the mode or sector or cross-cutting issue under discussion, thus potentially allowing for more detail and linkages to be established with relevant issues.

The disciplines within the services chapter which tend to be least common across the selected PTAs are those on subsidies, emergency safeguard measures, government procurement, MFN, and dispute settlement. Here three different approaches are evident.

The first is the tendency to have completely separate chapters on these issues, in addition to which these disciplines are often incorporated in chapters on other issues. This approach is most evident for the provision on dispute settlement. All but one of the selected agreements have a separate chapter on dispute settlement in addition to which dispute settlement provisions are found with a considerable amount of detail in chapters on investment or chapters on financial services, often with additional annexes on specific dispute related issues in these chapters. This approach clearly indicates that issues which are significant and cross-cutting, are covered in most PTAs by an overarching chapter and by explicitly indicating linkages with other important issues or sectors, thus providing scope for additional detail and customization.

The second approach seen is to cover the discipline outside the services text in a separate chapter, or to leave out the discipline altogether from the scope of the agreement (along with carve-outs for the same). This is applicable to the case of government procurement where as shown in Table 4, either the PTAs contain a separate chapter on government procurement where disciplines are approached in a crosscutting manner or there is no discipline on government procurement in the PTA. Even where provisions are included in the services text, the wording remains general as in the GATS, only noting that services procured for governmental purposes and not for commercial reasons are excluded, with no additional detail or rule making (as will be discussed later). The overall approach suggests that issues such as government procurement remain sensitive in many PTAs and there is thus no uniform approach.

The third approach identified is to either cover the provision within the chapter on services (usually rather loosely as will be discussed later) or to exclude it altogether from the agreement, with no separate coverage under specific chapters on these issues or in other related chapters where these provisions have a bearing. This approach has been taken in the cases of subsidies and emergency safeguard measures where there are either rather general provisions included within the services chapter or no coverage of these disciplines at all. In one of the selected PTAs, safeguards are discussed in the context of the investment chapter. The latter approach suggests that there are differing views between PTA participants on such disciplines, as has also been the case in the multilateral negotiations. This indicates that basic sensitivities and differences of opinion remain under the PTAs and that there has not been much advancement in rule making in these domains. 
It is interesting to note some of the patterns which emerge in terms of the coverage of disciplines, with regard to the nature of countries involved in the PTAs. While there is generally little difference in the coverage of the main provisions between the 3 North-South, the 3 South-South, and the 2 North-North agreements under discussion, a difference emerges in the provisions on government procurement, emergency safeguards, and subsidies, the areas where, as mentioned earlier, the sensitivities and nonuniformity of approaches are most evident. Both the North-North agreements (Japan-Singapore and USKorea) as well as the one North-South agreement involving Japan (JPEPA) have separate chapters on government procurement while none of the South-South PTAs have such provisions. Hence, government procurement is clearly an issue that is of negotiating interest for the developed countries (as also borne out by the multilateral discussion and differences seen between developed and developing countries on this subject).

While it is difficult to infer anything conclusive regarding the motivations and objectives of the different countries or the patterns that emerge based on the typology of the PTAs (N-N, N-S, S-S) given the small sample of PTAs, some differences and possible explanations are worth noting. For instance, while both the North-South and North-North PTAs involving Japan have government procurement chapters, the same is not true of Korea, whose North-South PTA with India does not cover government procurement either as a discipline in the services chapter or as a separate chapter, while its N-N PTA with the US includes a separate government procurement chapter. This suggests that, for a particular country, the approach to certain disciplines such as government procurement may vary across PTAs depending on its negotiating partner, which may also reflect differences in objectives, concerns, and bargaining power between different PTAs signed by a country.

Likewise, it is interesting to note that neither of the North-North PTAs contain provisions for safeguard measures within the services text, while this provision is included (though rather loosely as will be discussed later) in all the South-South PTAs and the two North-South PTAs excluding Japan. This pattern might reflect the fact that PTAs involving developing countries may be subject to more concerns over application of safeguard measures and thus the need to include explicit provisions to prevent the introduction of such measures. The absence of safeguard-related provisions in the two North-North agreements could also reflect the greater regulatory capacity on both sides to deal with such measures. Once again, it is noteworthy that both of Japan's PTAs cover safeguards in the context of the investment chapter, specifically with regard to cross-border movement of financial capital for reasons of macroeconomic management and stability.

There are additional provisions in the selected PTAs which are not present in the GATS. In the NorthSouth and South-South PTAs, these additional provisions mainly pertain to institutional issues such as setting up of sub committees on services trade or cooperation, or recognizing the linkages between services and investment in so far as explicitly noting the applicability of provisions in the investment chapter of the PTA to commercial presence-based delivery of services (i.e., the cross-cutting nature of key investment provisions). It is worth noting that all three PTAs involving India include a servicesinvestment linkage provision, which is not seen in any of the other South-South or North-South PTAs. The two North-North PTAs involve additional provisions which allow for extending privileges to third party firms operating in the partner countries or regarding non-applicability of market access and national treatment conditions to any non-conforming measures at various levels of government. What is evident here is that PTAs involving developing countries tend to focus on developing regulatory capacity while the developed-developed country PTAs may involve more detailed provisions, whose implementation presumes a certain level of regulatory capacity. 
Overall, even from the small sample of PTAs selected for discussion, it is clear that: (i) some disciplines such as government procurement or subsidies are not uniformly seen to be integral to services liberalization; (ii) some disciplines such as dispute settlement are seen to be generally applicable, thus warranting a cross-cutting approach within the overall PTA; and (iii) some disciplines such as safeguards or recognition are seen to be pertinent to specific issues, thus requiring explicit inclusion in relevant parts of the agreement. Although the sample size is small, there appear to be some broad differences between agreements involving only developed countries and those involving developing countries, where the former seem to go a bit further in terms of having specific chapters and additional annexes on Singapore issues like government procurement and investment. Finally, countries seem to follow a similar approach across PTAs in terms of the disciplines covered and the manner in which this is done, although differences may arise on specific disciplines especially in cases where the partner may have more negotiating leverage (like the US).

\subsection{Important cross-cutting issues: some general insights}

An examination of the 8 selected PTAs reveals that there are some cross-cutting issues which are uniformly addressed across agreements in the form of chapters or additional annexes, but there are also differences when it comes to the more "new age" regulatory issues. Table 5 provides an overview of the status of chapters or annexes in each of these PTAs.

Table 5 Presence of chapters and annexes in selected PTAs

\begin{tabular}{|c|c|c|c|c|c|c|c|c|c|}
\hline FTA Name & $\begin{array}{c}\text { Invest- } \\
\text { ment }\end{array}$ & $\begin{array}{l}\text { Move- } \\
\text { ment of } \\
\text { Natural } \\
\text { Persons }\end{array}$ & $\begin{array}{c}\text { Govern- } \\
\text { ment } \\
\text { Procur- } \\
\text { ement }\end{array}$ & $\begin{array}{l}\text { Comp- } \\
\text { etition }\end{array}$ & $\begin{array}{l}\text { Cooper- } \\
\text { ation }\end{array}$ & $\begin{array}{c}\text { Dispute } \\
\text { Settle- } \\
\text { ment }\end{array}$ & $\begin{array}{l}\text { Finan- } \\
\text { cial } \\
\text { Ser- } \\
\text { vices }\end{array}$ & $\begin{array}{l}\text { Telecom- } \\
\text { munication } \\
\text { Services }\end{array}$ & $\begin{array}{l}\text { Other } \\
\text { issues }\end{array}$ \\
\hline $\begin{array}{l}\text { India- } \\
\text { Korea } \\
\text { CEPA }\end{array}$ & $\sqrt{ }$ & $\sqrt{ }$ & & $\sqrt{ }$ & $\sqrt{ }$ & $\sqrt{ }$ & & $\sqrt{ }$ & $\begin{array}{c}\text { "Other" } \\
\text { includes } \\
\text { audio-visual } \\
\text { co- } \\
\text { production }\end{array}$ \\
\hline $\begin{array}{l}\text { India- } \\
\text { Singapore } \\
\text { CECA }\end{array}$ & $\sqrt{ }$ & $\sqrt{ }$ & & & & $\sqrt{ }$ & & & $\begin{array}{c}\text { "Other" } \\
\text { includes air } \\
\text { services, e- } \\
\text { ommerce, } \\
\text { education } \\
\text { and media }\end{array}$ \\
\hline $\begin{array}{l}\text { Japan- } \\
\text { Singapore } \\
\text { CECA }\end{array}$ & $\sqrt{ }$ & $\sqrt{ }$ & $\sqrt{ }$ & $\sqrt{ }$ & & $\sqrt{ }$ & $\sqrt{ }$ & $\sqrt{ }$ & $\begin{array}{c}\text { "Other" } \\
\text { includes } \\
\text { ICT, } \\
\text { broadcasting, } \\
\text { tourism etc. }\end{array}$ \\
\hline $\begin{array}{l}\text { Japan- } \\
\text { Philippines } \\
\text { EPA }\end{array}$ & $\sqrt{ }$ & $\sqrt{ }$ & $\sqrt{ }$ & $\sqrt{ }$ & $\sqrt{ }$ & $\sqrt{ }$ & & & \\
\hline $\begin{array}{l}\text { China- } \\
\text { Pakistan } \\
\text { FTA }\end{array}$ & & & & & & $\sqrt{ }$ & & & \\
\hline $\begin{array}{l}\text { China- } \\
\text { ASEAN } \\
\text { FTA }\end{array}$ & & & & & & $\sqrt{ }$ & & & \\
\hline $\begin{array}{l}\text { India-Sri } \\
\text { Lanka } \\
\text { CEPA }\end{array}$ & $\sqrt{ }$ & $\sqrt{ }$ & & & $\sqrt{ }$ & $\sqrt{ }$ & & & $\begin{array}{c}\text { "Other" } \\
\text { includes air } \\
\text { services }\end{array}$ \\
\hline
\end{tabular}




\begin{tabular}{|c|c|c|c|c|c|c|c|c|}
\hline $\begin{array}{l}\text { US-Korea } \\
\text { FTA }\end{array}$ & $\sqrt{ }$ & $\sqrt{ }$ & $\sqrt{ }$ & $\sqrt{ }$ & $\sqrt{ }$ & $\sqrt{ }$ & $\sqrt{ }$ & $\begin{array}{l}\text { "Other" } \\
\text { includes E- } \\
\text { commerce, } \\
\text { labour and } \\
\text { environment }\end{array}$ \\
\hline
\end{tabular}

Source: Based on an analysis of the legal texts of the selected PTAs

As seen from the table above, the most prevalent issue, which is covered in a chapter in all these PTAs, is that of dispute settlement, indicating the importance of legal frameworks for operationalizing and enforcing commitments and rules under all agreements. Next most important are the issues of investment and movement of natural persons, which are present in all but two agreements (China-Pakistan and China-ASEAN). All types of PTAs, N-S, N-N, and S-S, have chapters on these two issues. Cooperation chapters mostly feature in $\mathrm{N}-\mathrm{S}$ and $\mathrm{S}-\mathrm{S}$ agreements, although, as highlighted earlier, there are provisions on cooperation within the services text in several PTAs (e.g., China-Pakistan, China-ASEAN), even if there is no separate chapter on cooperation. But it is worth noting that neither of the N-N PTAs included in this sample have chapters on cooperation (or provisions within the services text on cooperation), indicating that a certain level of regulatory capacity and institutional development has already been achieved by such countries. Competition policy and government procurement are the least common areas to be covered under separate chapters. Government procurement chapters are present in both the N-N PTAs and in the one N-S PTA featuring Japan (as also highlighted earlier), but are not present in any of the S-S PTAs. Competition policy chapters, similarly, are only found in the N-N PTAs or the N-S PTAs involving Japan and Korea, and are not present in any of the S-S PTAs. Thus as highlighted earlier, government procurement and competition are clearly not priority areas for agreements involving only developing countries, and are probably more sensitive issues for the latter.

As regards additional chapters or annexes, it is evident that only agreements involving developed countries contain annexes on financial services, while none of the N-S or S-S PTAs have a financial services chapter or annex. In the case of telecom services, barring the India-Korea PTA, there is no such annex in any of the other PTAs involving developing countries whereas both the N-N PTAs in the sample have such a chapter. What this reveals is that on issues or in sectors that involve considerable regulatory cooperation and institutional capacity, developed country PTAs are most likely to go further by including specific chapters (with elaborate rules as will be seen later). Annexes or chapters on "other" sectors or issues mainly relate to emerging areas such as audiovisual, e-commerce, information and communication technology, education, and environmental services, areas such as air transport services where bilateral cooperation is important, or sectors such as tourism where there is considerable commercial potential and scope for cooperation. It is interesting to note that all the PTAs involving India, whether with developed or developing countries, contain chapters on quite a variety of "other" issues or sectors, possibly reflecting India's competitiveness in services and its interest in leveraging its PTAs to explore commercial and collaborative opportunities in a range of service sectors. Both the N-N PTAs also include chapters on "other" issues, either relating to technology-intensive or commercial considerations (JapanSingapore) or to social and environmental considerations (US-Korea). It is also worth noting that only the PTA with the US incorporates social and environmental issues none of the intraregional Asian PTAs (including the other PTA involving Korea) cover such non-economic issues in additional chapters. Thus, the variation with regard to the inclusion of additional chapters in PTAs possibly also reflects differences in negotiating approaches and bargaining power for the same country under different PTAs depending on its negotiating partner. 
A comparison of the above coverage of chapters and annexes in the selected PTAs with that under the GATS indicates that PTAs have generally gone beyond the GATS in inscribing more sector- or issuespecific provisions. Issues such as competition or cooperation are neither included as annexes nor as provisions within the services chapter of the GATS. Sensitive issues such as environment and labour are not covered under the GATS annexes. This expanded framework of rules in the form of additional chapters under PTAs confirms the well known fact that countries are able to introduce sensitive issues into PTAs which are difficult to incorporate into the multilateral framework (labour and environment) and that the ability to do this is related to the bargaining power of the partner countries (US in US-Korea). The difference in the scope of chapters under these PTAs from that found under the GATS indicates that PTAs have been able to address technological advancements and new opportunities such as e-commerce, ICT, and audiovisual services, and further that PTAs have been able to address specific concerns and interests of the negotiating partners by including specific sectoral chapters. But the area where the deviation from the GATS is most striking is that of investment. The GATS does not contain any separate annex on investment while almost all the PTAs contain separate chapters on investment with detailed provisions on rights of investors and judicial procedures to be followed in the case of investor disputes (as will be discussed later, in addition to explicit provisions in the services chapter on services-investment linkages as highlighted earlier). Thus, the PTAs do advance rule making by expanding the scope of the negotiating framework by including chapters and provisions on additional issues, particularly with respect to investment and emerging areas in services trade.

\subsection{Carve-outs and broader scope and coverage issues in the selected PTAs}

While it is important to examine the extent to which the PTAs are similar in their scope across disciplines and additional issues or sectors, it is equally important to examine to what extent they leave out sectors and subsectors. Table 6 summarizes the carve-outs for each of the selected PTAs.

Table 6 Sectoral and other common carve-outs in selected Asian PTAs

\begin{tabular}{|c|c|c|}
\hline FTA Name & Carve Out(s) & Remarks \\
\hline India-Korea CEPA & $\begin{array}{l}\text { Air transport, }{ }^{\mathrm{a}} \text { services supplied in } \\
\text { the exercise of governmental } \\
\text { authority }\end{array}$ & \\
\hline India-Singapore CECA & $\begin{array}{l}\text { Air transport, }{ }^{\text {a }} \text { services supplied in the } \\
\text { exercise of governmental authority }\end{array}$ & \\
\hline Japan-Singapore CECA & $\begin{array}{l}\text { Air transport, }{ }^{\text {a }} \text { services supplied in the } \\
\text { exercise of governmental authority }\end{array}$ & \\
\hline Japan-Philippines EPA & $\begin{array}{l}\text { Air transport, a services supplied in } \\
\text { the exercise of governmental } \\
\text { authority, Other }\end{array}$ & $\begin{array}{l}\text { "Other" chapter does not apply to } \\
\text { cabotage in maritime transport } \\
\text { services }\end{array}$ \\
\hline China-Pakistan FTA & 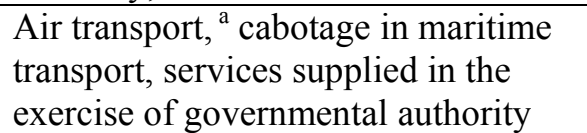 & \\
\hline China-ASEAN FTA & $\begin{array}{l}\text { Air transport, }{ }^{\text {a }} \text { services supplied in the } \\
\text { exercise of governmental authority }\end{array}$ & \\
\hline India-Sri Lanka CEPA & $\begin{array}{l}\text { Services supplied in the exercise of } \\
\text { governmental authority }\end{array}$ & \\
\hline US-Korea FTA & $\begin{array}{l}\text { Air transport, }{ }^{\mathrm{a}} \text { services supplied in the } \\
\text { exercise of governmental authority }\end{array}$ & \\
\hline
\end{tabular}

Source: Based on an analysis of the legal texts of the selected PTAs 
${ }^{a}$ All but three subsectors under air transport services are excluded from the scope of the PTAs.

As seen above, air transport services, other than three subsectors, namely aircraft repair and maintenance services, computer reservation system services, and sales and marketing are excluded from the scope of all the PTAs. This exclusion is the same as that under the GATS. What is interesting to note that is that while air transport services, given their dependence on bilateral air service agreements and the presence of other international regulatory frameworks to govern this sector, are not conducive to multilateral discussions, even under PTAs, they are carved out. However, in some of the PTAs, air services are separately addressed through an additional chapter to address sector-specific liberalization issues. Another area that is commonly excluded is cabotage in maritime transport services, as is also the case under the GATs. There is also a carve-out for financial services in two of the agreements involving India, although the India-Singapore CECA does not carve out this sector, reflecting the importance of this sector for Singapore. Thus carve-outs in the PTAs reflect concerns and sensitivities similar to those under the GATS. However, as shown earlier, PTAs tend to include customized chapters on many other services and cross-cutting issues. Hence, they have the scope to go further on rule making or intent than the GATS (though as will be highlighted later when examining the content of these provisions, these additional chapters may remain best-endeavour in nature).

Apart from specific carve-outs, it is worth noting that the PTAs are very similar to the GATS in the way they define their scope and coverage. The services chapters across all the PTAs in this sample commence by highlighting the scope and coverage. In all the PTAs, in addition to excluding air transport services (barring the three selected segments noted above) and cabotage services, the texts clearly note that the measures will not apply to subsidies provided by governments or state enterprises (including grants, government supported loans, guarantees and insurance) and that measures relating to immigration laws and regulations, and measures affecting natural persons seeking employment or nationality or residence in the partner country's market will be excluded. Some of the PTAs also note that the measures affecting trade in services will not apply to government procurement (although there may be chapters specifically on some of these aforementioned excluded measures where specific negotiating issues and progressive liberalization are addressed). In addition, all the PTAs conform with the GATS in that they exclude services supplied in the exercise of governmental authority which are not supplied on a commercial basis or in competition with one or more service suppliers, with this exclusion being applicable to all levels of government, central, state, local, and provincial. Thus the GATS text appears to be a reference for the PTA texts with regard to broader scope and coverage issues.

\section{The substantive content of disciplines and chapters in selected PTAs}

While it is useful to examine the scope of disciplines and chapters, it is the substantive content of these disciplines and chapters that determines whether the PTAs do indeed go further than the GATS when it comes to rule making and liberalization intent. The discussion that follows in this section has two parts. The first takes a closer look at the content of key disciplines found in the services chapter of the PTAs and compares this with the content of the same disciplines in the GATS text, to see to what extent they are broadly similar and to what extent they diverge, what these differences might imply, and whether there are any identifiable patterns with regard to the nature of countries involved and the content of these disciplines. The discussion also examines some new provisions which are found in the selected PTAs, but are absent from the GATS. The second part of the discussion in this section examines the substantive content of chapters on key issues (such as investment or movement of natural persons) in the selected 
PTA disciplines to assess the extent to which they are similar to or different from the annexes on similar issues under the GATS. Once again there is an attempt to identify the relationship, if any, between the types of countries involved in the PTAs and the content of these chapters.

\subsection{Content of key disciplines: some insights}

The following discussion highlights and compares the content for several disciplines. These include: MFN, market access, national treatment, domestic regulation, transparency, mutual recognition, other areas (subsidies, government procurement, emergency safeguard measures), and additional issues (services-investment linkages, cooperation, institutional issues), as highlighted in Table 4 above.

\subsubsection{Most-favoured nation provision}

The MFN provision is one of the fundamental principles of the multilateral trading system and thus also of the GATS. Under the GATS, the MFN provision states that each member will accord immediately and unconditionally similar treatment to third country services and service suppliers with respect to measures covered by the GATS. If one examines the text of the MFN provision or "Review of MFN commitments" as it is termed in some of the selected PTAs, one finds that the broader intent of extending similar treatment to third parties is present in the PTA provisions on MFN, there are slight differences in wording and nuancing of the intent. For instance, the India-Korea CEPA and the India-Singapore CECA, state that if one of the parties enters into an agreement on services trade with a third party, it will give consideration to a request by the other party for incorporation of no less favourable treatment than that provided in the new agreement, while maintaining the balance of concessions in the overall agreement. This is not as clear a mandate to extend similar treatment as it only says that consideration will be given to such extension requests by the signatories of the India-Korea CEPA or India-Singapore CECA. Likewise, the India-Sri Lanka CEPA has a loose provision on MFN. In contrast, the Japan-Philippines EPA contains the more standard GATS form of MFN provision, wherein parties are to accord no less favourable treatment to third parties with exceptions for those activities, sectors or subsectors listed in the annex on MFN exemptions. Hence, it is a stronger version of MFN than that found in the India-Singapore and India-Korea PTAs. The US-Korea PTA's MFN provision similarly is closer to the wording found under the GATS. There is one difference though between even the stronger versions and the GATS MFN provision in that none of the PTAs use the terms "unconditionally" and "immediately" as would be expected given their preferential nature. Thus, they are always somewhat softer than the GATS. It is important to note, however, that the MFN provision is pertinent only to the extent that the commitments made under the PTAs go beyond the level of unilateral liberalization and are truly preferential in nature, in which case the extent to which MFN is accorded or not becomes important for determining the possibilities for trade creation or diversion.

\subsubsection{National Treatment}

The national treatment under the GATS requires members to accord no less favourable treatment to services and service suppliers of other members, than what is accorded to their own, subject to conditions and qualifications set out in the sectoral commitment schedules. Formally identical or formally different treatment may be accorded. Less favourable is further defined as relating to treatment which modifies the conditions of competition in favour of the member country's services or service suppliers. Further, countries would not be required to compensate for any inherent competitive disadvantage resulting from the foreign character of the relevant services or suppliers. 
The selected PTAs almost all adhere to this content and wording in their provisions on national treatment. The one difference that emerges is that the clause on not being required to compensate for inherent competitive disadvantages is brought explicitly into the national treatment clause in some of the PTAs, while it is present as a footnote to this provision in the GATS. The question is whether this can be interpreted as not only clarificatory in nature but also as an integral part of understanding measures affecting services and service suppliers in that measures may have differential effects owing to inherent disadvantages on account of being foreign, though they may not be per se discriminatory. This is an important issue in services trade and the PTAs make this recognition explicit.

In some of the PTAs, additional clauses are present. The India-Singapore, India-Korea, and India-Sri Lanka agreements include two additional clauses. The first states that subsequent establishment, acquisition and expansion of investments by a service supplier that is incorporated, constituted, set up or otherwise in one of the parties and owned by a service supplier of the other party is to be treated as an investment of the other party for purposes of determining applicable treatment. Thus, these PTAs are forward looking in that they extend similar and, as noted, better treatment to new investments in services by one of the member countries in the other member country's market. It is also worth noting that while allowing for better treatment of future investments, the footnote to this clause also states that such improvements would not mean automatic additions to India's schedule of specific commitments. Thus, there is a possibility of progressive liberalization but without requiring grandfathering of earlier investments under similar, more liberal, terms and conditions. The second additional clause in these three PTAs pertains to the applicability of the national treatment provisions at the regional and local levels, thus addressing sub-federal issues in the application of measures affecting services trade and investment in countries like India.

The US-Korea agreement is also quite different in wording and scope of national treatment from the other PTAs in this sample. It excludes the use of the term "services" and makes mention only of "service suppliers", thus narrowing the scope potentially to modes where there is explicit presence of service suppliers (modes 3 and 4 in particular). Like the Indian PTAs, it has an additional clause which states that this national treatment provision would apply at the level of the regional government, in like circumstances. Thus this provision is explicitly extended to apply at sub-federal levels of government although the conditionality of "like circumstances" does proscribe this extension to some degree. There is also no mention in this agreement of formally similar or identical treatment or of inherent disadvantages. So, there is somewhat more ambiguity in this agreement about the scope and interpretation of the national treatment provision.

\subsubsection{Transparency}

The GATS provision on transparency requires prompt publication of all relevant measures of general application and all international agreements to which the members are signatories, which have a bearing on the agreement. Where this is not possible, the information is to be made publicly available. In addition, members are to provide notification of the introduction of or changes to regulations and procedures which would affect their commitments and should also respond promptly to all requests from other members seeking information. There is also a requirement to establish inquiry points within 2 years, with some flexibility for developing country members. There is also scope to notify the Services Trade Council if measures are taken by the other member, which affect the operation of the agreement.

In the PTAs, for the most part, the GATS provision on transparency holds verbatim. Some of the PTAs, such as the China-Pakistan and the China-ASEAN agreements, specifically refer to the GATS Article III 
on transparency and note that this provision of the GATS is incorporated in and forms an integral part of the PTA. Others such as the India-Korea and the India-Singapore PTAs repeat the clauses of the GATS under the transparency article. However, there are instances where the PTAs make specific points which do not appear in the GATS provision. For example, the Japan-Philippines EPA mentions the application of transparency to licensing and qualification procedures through an enquiry point, where the latter would be notified to the other party by a diplomatic note as soon as the agreement enters into force. Furthermore, there is a clause which specifies that a public list has to be provided of all existing measures, at all levels of government in both Japan and the Philippines, falling within the scope of the PTA's services chapter, and which are inconsistent with the market access and national treatment provisions, whether or not these are included in the specific commitments. It also specifies that this list would need to provide information on the sector or subsector, the nature of the inconsistency, the legal source or authority of the measure, and a description of the measure, with provision for an annual review of this list. Thus, in effect, the transparency requirement in the JPEPA is more specific about certain measures, namely those pertaining to movement of natural persons (licensing and qualification related procedures) which is a sensitive issue for Japan and a major negotiating issue in this particular agreement. The institutional requirement is also more stringent as the nature of the listing. Thus it is evident that on issues that are particularly important in a PTA, members may go beyond the GATS provisions on transparency to address their specific interests and insist on more binding obligations.

The US-Korea agreement is again different in nomenclature and content. The article on transparency in the services chapter is called "transparency in developing and applying regulations" where regulations are explicitly noted as including those establishing or applying to licensing authorization or criteria at different levels of government. The provisions under this article in the US-Korea agreement appear to be weaker than those under the GATS. For instance, one clause requires each party to establish or maintain appropriate mechanisms for responding to enquiries although there is no specific mention of contact points or any institutional directions for what might constitute such appropriate mechanisms. Thus more leeway is provided to the two parties. A second clause notes that if a country does not provide advance notice of or opportunity for comment on regulations proposed for adoption, then "to the extent possible" it will address the reasons for not doing so. The latter is a very openly worded clause as it not only allows countries the scope not to provide information in advance, but also does not mandate the country to provide the reasons for not informing the other party, leaving this dependent upon the feasibility of doing so. The third clause of this transparency provision calls for reasonable time to be allowed between publication of final regulations and their implementation. This is also absent from the GATS. There is also reference to a separate chapter on transparency and consistency with provisions under that chapter. Hence, the US-Korea agreement is on the whole much more ambiguous about what is meant by transparency, how this is to be ensured, and how much flexibility countries can retain in this regard. In contrast, the other PTAs either repeat the scope and intent of the GATS transparency provision or go a bit further as in the case of JPEPA.

\subsubsection{Market Access}

This discipline governs the extent of, and conditions for, entry of foreign service suppliers into other markets under the GATS. The market access provision in the GATS is conditional upon the limitations inscribed in the member countries' commitment schedules. Hence, unless otherwise inscribed in the commitments, members are not permitted to restrict entry based on limitations on the number of foreign service suppliers, the total value of their transactions, the total quantity of service output, the number of natural persons employed in a certain sector, on the type of legal entity, or on the extent of participation by foreign capital. 
In most of the PTAs, the content for this discipline is identical to that found under the GATS, including the various limitations whose use is prohibited unless specifically included in the commitments undertaken. However, there are some noteworthy differences in content in the case of three of the selected PTAs. The US-Korea agreement does not include limitations on participation of foreign capital in terms of maximum foreign equity limits or total value of foreign investment in its list of proscribed market access measures, while retaining all the others. The two agreements involving Japan have additional notes with regard to the movement of capital where the latter is an essential part of the service and where the country has taken a market access commitment for the supply of this service through mode 1 or mode 3 . In such a case, the party cannot put restrictions on the movement of capital. Thus, both these PTAs make it harder for the parties to inscribe limitations on cross-border movement of capital when this is integral to entering the other market in a particular service sector and when that service sector is covered by a market access commitment. Another additional note present in both the PTAs that involve Japan states that limitations on inputs for the supply of a service are not covered even if limitations on the total number of service operations or on the total quantity of services output expressed in terms of numerical limits or quotas or economic needs test requirements are not permitted. This is an interesting exclusion to the extent that it has a particular bearing on movement of natural persons. It implies that although the parties may not be able to restrict the number of operations, the number of foreign service suppliers required to conduct these operations can still be restricted. Thus seemingly innocuous notes in some PTAs may allow scope for maintaining limitations that are of significance to their partner countries.

\subsubsection{Domestic Regulation}

In view of the importance of domestic regulations in governing services trade and investment flows, the GATS article on domestic regulation requires members to ensure that all such measures in sectors where members have undertaken specific commitments are to be administered in a reasonable, objective, and impartial manner. Further, the provision also calls for judicial or administrative mechanisms for review and remedy, although consistent with member countries' legal systems. The time frame for authorization of service supply covered under specific commitments is expected to be reasonable and information if sought has to be provided for any applications requiring authorization. There is also specific mention of measures relating to qualification requirements and procedures, technical standards and licensing requirements and ensuring that the latter do not constitute unnecessary barriers to services trade, by requiring transparency, objectivity, and so on. in the use of such measures where commitments have been undertaken. Further, members are not to apply requirements which negate or reduce their specific commitments. There is also a clause to take into account international standards where relevant and to provide procedures for verifying the competence of professionals of other members.

The PTAs are broadly in line with the above-mentioned domestic regulatory principles and often repeat the same clauses. But, again, there is some variation on specific issues added in the PTAs but which are not present in the GATs text. In the India-Singapore and India-Korea PTAs, for instance, there is a specific mention of joint review of the results of the negotiations on disciplines pertaining to qualification and licensing requirements and procedures and technical standards with a view to their incorporation into the services chapter of this PTA. The clause requiring parties to ensure that such requirements and procedures do not nullify or impair their specific commitments is made contingent on the incorporation of the disciplines developed in this regard under the WTO. Hence, clearly this PTA not only uses the GATS as a reference for domestic regulatory principles but also looks ahead at prospective developments in the GATS for their inclusion into the PTA text. The India-Sri Lanka agreement is similar in this regard. The US-Korea and the China-ASEAN agreements also incorporate the possibility of taking into account the 
results of similar negotiations. The Japan-Singapore PTA, however, does not include such a forward looking clause benchmarking itself with developments under the GATS on this discipline.

The China-Pakistan FTA while mostly similar to the GATS in its provision on domestic regulation, has an additional clause which is not found in any of the other PTAs. This clause requires the parties to consult periodically to determine the feasibility of removing any remaining nationality requirements for licensing and certification of each other's service suppliers. Thus, the specific issue of domestic regulations which link provision of a service to nationality is given importance in this PTA. The ChinaASEAN agreement similarly includes additional detailed clauses. There is, for example, a sub-clause which requires competent authorities to identify all additional information in the case of an incomplete application and to remedy any deficiencies, to provide scope for resubmission of an application.

There is also deviation from the GATS with regard to the inclusion of additional conditionalities such as in the US-Korea agreement. In this agreement, in one of the clauses on domestic regulation, it states, "while recognizing the right to regulate and to introduce new regulations for meeting national policy objectives" while noting that qualification requirements and procedures, technical standards, and licensing requirements are not to constitute unnecessary barriers to services trade. This makes the provision somewhat more nuanced and flexible by specifying the need for domestic regulations to meet national objectives.

While the clauses included under the domestic regulation discipline are more or less the same in the PTAs as under the GATS, in the Japan-Singapore PTA the specific reference to commitments regarding professional services and provision of adequate procedures to verify the competence of professionals, which is present in the GATS, is missing. Thus the scope is narrower in this PTA than in the GATS in that the parties are not mandated to ensure such procedures even where commitments have been taken.

There is also deviation with regard to the nomenclature used in this provision. In the Japan-Philippines agreement there is no discipline termed, "domestic regulation". However, if one examines the content of the corresponding provision in this PTA, the domestic regulation discipline appears in the form of a provision termed, "authorization, licensing or qualifications" wherein the regulations pertaining to authorization, licensing, and qualification of service suppliers are covered. The principles are the same in terms of ensuring objectivity, transparency, being no more burdensome than required, and not constituting disguised restrictions, but the scope is considerably narrower than that under the GATS. No generally applicable domestic regulatory measures with a bearing on trade in services are covered, only the narrow subset of domestic regulations pertaining to qualification and licensing issues.

Thus compared to other disciplines, in the case of domestic regulation, one finds much more variation across the PTAs and in relation to the GATS. There are additional clauses and sub-clauses, or conditional statements included within the clauses, or outright exclusions from the scope of the provision. But the underlying principles of objectivity, transparency, and impartial review, continue to apply.

\subsubsection{Mutual Recognition}

Mutual recognition is another discipline where one finds some variation among the PTAs and also in comparison with the GATS. The GATS gives countries the right to choose whether to accord recognition to the supplier of the other country and the manner in which to accord recognition, whether by harmonization, or by mutual agreement, or autonomously. It also calls upon members to provide adequate opportunity to other members to negotiate entry into such mutual arrangements on recognition or negotiate comparable ones with other countries. Thus, there is intent to extend the benefits of recognition 
to more members. Further, the standards and criteria used for according recognition are not to be applied in a discriminatory manner across members or to be a disguised restriction on services trade. Wherever appropriate, multilateral criteria and international standards are to be used in granting recognition. The Council for Trade in Services is to be informed about any mutual arrangements.

The discipline on recognition takes very different forms under the selected PTAs all of which, except the Japan-Singapore agreement, contain this provision. While these PTAs replicate the GATS clauses regarding according recognition autonomously, or through mutual arrangement, or through harmonization and of providing opportunity to other parties, several go further by specifically calling upon the two parties to enter into negotiations on recognition. The China-ASEAN PTA, for instance, includes a specific paragraph which says that two or more parties may enter into, or encourage their relevant competent bodies to enter into, negotiations on recognition of qualification and licensing requirements and procedures in order to meet their respective standards or criteria for authorization, licensing or certification. Likewise, the China-Pakistan agreement asks both sides to facilitate the development of mutual recognition arrangements among professional or regulatory bodies via discussions and exchange of information on focal points to be appointed.

A similar degree of specificity with regard to launching discussions and with regard to specific sectors and services is found in the India-Singapore CECA. The latter calls upon the parties to ensure that their respective professional bodies in specific services (accounting and auditing, architecture, medicine, dentistry and nursing) negotiate and conclude within one year of the Agreement's entry into force arrangements for mutual recognition of qualifications and experience, including the details of the extent and scope of this recognition. In other regulated sectors, if a request is made for discussions, then the parties would encourage their relevant professional bodies to enter into negotiations. However, delays or failures to conclude such arrangements are not to be regarded as a breach of obligations and thus would not be subject to dispute settlement, with continual review of progress. Furthermore, disputes arising out of or under such arrangements will not be covered under the dispute settlement mechanism of this PTA. The specific mention of entry into negotiations for achieving mutual recognition and with additional specificity regarding the sectors for consideration takes this PTA further than the equivalent provision under the GATS. However, there is no clear time-bound nature to the conclusion of these negotiations (even though the India-Singapore CECA requires discussions to commence within a year of the entry into force of the agreement) in so far as delays or failure to conclude are not to be deemed a breach of obligations and the dispute settlement mechanism is not applicable. The India-Korea CEPA similarly excludes the application of dispute settlement provisions in case of failure or delay in negotiating such arrangements. Thus, while being specific with regard to sectors, the provisions are rather soft in terms of implementation and timelines.

There is, however, one clause which is missing in all these PTAs although present in the GATS. This is the reference to international standards. There is also no reference to according adequate opportunity to extend the arrangements reached between the two parties to third countries or that the criteria or standards agreed upon would not be applied in a discriminatory manner to suppliers of other countries. Thus, while the PTAs go a little further than the GATS in some respects, they are also weaker with regard to extending achievements outside the PTA and thus potentially may provide scope for trade diversion.

\subsubsection{Other provisions - government procurement, emergency safeguards, subsidies}

As noted above, provisions on issues such as government procurement, emergency safeguards, and subsidies are not commonly found in the PTAs. Where these disciplines are found, generally, they either 
replicate those found in the GATS text, take a more nuanced and weaker form, or are explicitly specified as being excluded from the scope of the services chapter. It is also worth pointing out that some of these disciplines are covered in the form of chapters in the PTAs rather than as disciplines within the services chapters.

\section{(a) Government procurement}

The GATS discipline on government procurement states that the articles on MFN treatment, market access, and national treatment do not apply to laws, regulations or requirements governing the procurement by governmental agencies of services purchased for governmental purposes and not for commercial resale or for the use in supply of services for commercial sale. The discipline also calls for multilateral negotiations on government procurement of services within two years of the GATS' entry into force.

Among the selected PTAs, three contain disciplines on government procurement within the services chapter. The India-Singapore and India-Sri Lanka PTAs which have provisions on government procurement duplicate the GATS in terms of the scope of the agreement with regard to government procurement but do not make any mention of continuing future negotiations in this area. However, even where there is no separate discipline on government procurement in the PTAs, there is reference to the matter in the provision on scope and coverage in their services chapters, wherein it is noted that the measures discussed in the chapter would not apply to government procurement, without any conditions. Hence, the carve-out for government procurement is stronger in the PTAs than under the GATS to the extent that the exclusion is unqualified and there is also no mention of future discussions on this issue. However, as highlighted earlier, some of the PTAs also contain a separate government procurement chapter which is more detailed (as will be discussed later). Thus, in general, as in the multilateral context, there has been little progress on government procurement in the regional context.

\section{(b) Subsidies}

The GATS discipline on subsidies is rather open-ended and embryonic in nature. It only calls for members to recognize that subsidies could, under certain circumstances, distort trade in services and that member countries should try and develop multilateral disciplines to avoid such effects and negotiate the feasibility of countervailing procedures. In addition, the discipline also takes note of the role subsidies can play in development and accords developing countries flexibility in this regard. The discipline also calls for exchange of information on subsidies and allows members to request consultations if adversely affected by subsidies.

Four of the selected PTAs have disciplines on subsidies. A striking aspect of this discipline in the PTAs is that it is even weaker than that found under the GATS. The subsidies provision in the China-ASEAN PTA, for example, states that the agreement does not apply to subsidies or grants provided by either party or to conditions related to the receipt of such subsidies or grants. Moreover, this exclusion is specified as being independent of whether such subsidies or grants are offered only to domestic services, consumers, and suppliers, which makes it a strong carve-out. However, as in the case of the GATS, the PTA provision also mentions that if such measures are seen as distorting trade, then consultations may be sought and, as specified in the GATS, the PTA also requires members to exchange information on subsidies relating to trade in services and to review their treatment when disciplines are developed in the WTO. Thus, the PTA ties this discipline to developments under the GATS. 
The India-Korea, India-Singapore, and India-Sri Lanka PTAs similarly carve out subsidies from the scope of the services chapter. The subsidies provisions in these PTAs again refer to developments in multilateral negotiations on subsidies and information exchange. But these agreements go a step further in that they also outline what is meant by information exchange between the two parties. The provision specifies that this information would pertain to laws and regulations under which the measure is introduced, the form of the measure, the policy objective and purpose of the measure, the dates and duration of the programme and time limits, and the eligibility requirements and criteria applied. Such detail is not provided under the GATS. Moreover, the provision also states that dispute settlement related provisions will not apply to any such discussions. Thus, as in the case of government procurement, there is little development of the subsidies discipline under PTAs, barring some clarification on the content of information exchange.

\section{(c) Emergency safeguard measures}

Emergency safeguard measures is another area where the GATS discipline remains embryonic, calling for multilateral negotiations on this issue based on non-discrimination and stating that the results of such discussions are not to enter into force within three years from the entry into force of the GATS. However, this provision also permits countries to declare their intent to modify or withdraw their specific commitments within a year if it is not possible to wait for 3 years. However, the latter provision would not apply after 3 years. Hence, the GATS does not permit countries to respond to surges in imports by using safeguard measures.

In the PTAs, one finds considerable variation in wording and intent for this discipline. While the ChinaPakistan FTA contains a verbatim repetition of the GATS provision on emergency safeguard measures, the others are quite different. The China-ASEAN PTA for instance, does not go so far as the GATS regarding the possible withdrawal or modification of commitments. Instead it calls for the parties to discuss such measures which may be adversely affecting their services trade. It requires that any such measures be undertaken through mutual agreement, and that due consideration be given by the other party in such circumstances. Hence, the wording is more nuanced. The India-Korea and India-Singapore PTAs prohibit both parties from taking safeguard action or from initiating or continuing with any safeguard investigation against services and service suppliers. However, in the India-Sri Lanka agreement, India's stance is different, permitting safeguard measures to be taken for a period of 6 months with an initial period of 3 months. There is also reference to the GATT Agreement on Safeguards requiring identification of domestic industry which produces like or directly competitive services. The provision does not, however, seem to be operationally feasible or meaningful as a 3- or 6-month time frame is unlikely to be sufficient for the domestic service to recover and because identification of like services or estimation of injury caused is likely to be very difficult in the case of services. Thus, ESMs are clearly a sensitive issue, with some countries providing scope for discussions in this area, others excluding outright the possibility of such measures, and yet others including them in a manner that may not be useful. ${ }^{7}$

\subsubsection{Additional provisions in PTAs}

There are several common provisions found in the sample of selected PTAs which are not found in the GATS. These include provisions on services-investment linkages, for sub-committees on services trade, on cooperation, and others. A few of these are highlighted below.

\footnotetext{
${ }^{7}$ In several PTAs, which do not contain a provision on safeguard measures in the services chapter, such a provision is found in the chapter on investment, as discussed later.
} 
Two of the PTAs contain provisions for the establishment of a sub-committee on trade in services. The India-Sri Lanka CEPA calls for the setting up of such a sub-committee to review commitments to enable further liberalization, to review the implementation and operation of the services trade chapter, and the implementation of MRAs. However, no details are provided regarding the structure and composition of the members of such a body or its functioning, barring mention that there should be representatives with the required expertise and an inaugural meeting within a year of entry into force of the chapter on services. No such provision is present in the other two PTAs involving India in this sample. This may reflect India's existing experience with Sri Lanka with regard to the India-Sri Lanka Free Trade Agreement and the recognition that institutional mechanisms can help in operationalizing this agreement, or possibly concerns on the part of Sri Lanka regarding competition in services from Indian suppliers. But it is worth noting that the provision is rather vague and does not give any operational framework or guidelines for such an institutional mechanism.

The JPEPA contains a similar provision for setting up an institutional mechanism for the effective implementation and operation of the services trade chapter. Again, the provision calls for a review of commitments to enable progressive liberalization, exchange of information on domestic laws and regulations, and discussion of issues related to services trade. But further details, for example, in terms of concrete timelines, how this mechanism would actually function, and who the members would be are not provided.

The China-Pakistan agreement likewise calls for the setting up of a Committee on Trade in Services to review commitments relating to measures affecting services trade and to review the implementation and operation of this agreement. Specific mention is made of the need to review and discuss the provisions on mutual recognition and emergency safeguard measures, to report the outcome of the discussions to the Free Trade Commission, and to carry out other (unspecified) functions. Issues such as recognition and safeguards are thus clearly recognized as focus areas for this committee. However, once again, there is no detail on how this committee should be constituted, how it would operate, and the operational framework is left open to further discussions.

Hence, in all cases, while the inclusion of a provision for the establishment of a committee or subcommittee on services trade indicates the need to set up institutional structures to oversee liberalization and proper implementation of the PTAs, there is little operational or substantive content to this discipline. It is also worth noting that the N-N PTAs do not include such a provision, possibly because institutional structures are in place on both sides.

\section{(b) Services-investment linkages}

There is a provision on services-investment linkages in the 3 PTAs involving India. The provision specifies that certain articles of the chapter on investment (those relating to minimum standards of treatment, transfers, expropriation and compensation, losses and compensation, subrogation, special formalities and information requirements, access to administrative and judicial procedures, dispute settlement, and entry into force, duration, and termination) would apply to measures affecting the supply of a service through commercial presence, if these measures relate to investment. This application would be independent of whether the service sector has been scheduled or not in the specific commitments. It is further specified that certain provisions of the investment chapter would apply to the supply of financial 
services through commercial presence to the extent that such measures relate to investment, again independent of the whether the service concerned has been committed or not. Hence, certain disciplines outlined in the investment chapter (discussed in detail below) are seen as overarching ones. By explicitly noting this linkage, the investment-related regulatory framework that would be applicable to services trade through commercial presence is specified.

\section{(c) Cooperation}

The 2 PTAs involving China contain this additional provision. The wording is the same in both cases. The provision requires the parties to strengthen cooperation efforts in services, including in sectors not covered by existing cooperation arrangements. The discipline calls for the countries to discuss and mutually agree on the sectors covered and to develop cooperation programmes to improve their domestic capacities, efficiencies, and competitiveness. The basic intent here is capacity building and gradual expansion of sectors for liberalization. There is, however, no specificity in this provision regarding what the institutional mechanisms would be, the timeframes, the scope, or how outcomes are to be incorporated into the commitment framework and future negotiations. Thus, the framework often lacks clarity.

\section{(d) Other provisions}

There are a few provisions which are quite distinctive and are found in one of the PTAs. For instance, the US-Korea agreement contains an article on local presence, wherein it is specified that neither party can require a service supplier of the other country to establish or maintain a representative office or any form of enterprise or to be a resident in its country as a condition for cross-border supply. This means that local presence conditions cannot be attached to commitments in mode 1. There is also a provision on nonconforming measures which specifies that the market access, national treatment, MFN, and local presence provisions would not apply to any existing, continued or renewed, or amended non-conforming measures that are maintained at the central, regional, or local levels of government as laid out in its Annex on Government Procurement. So, in effect, the carve-out for government-provided services is extended to government-procured services that fall within certain threshold values.

While most of the PTAs make reference to third parties in that any subsequent agreements or recognition granted to the latter by one of the parties are to be extended to the other party, only one of the PTAs in this sample includes a provision for service suppliers of non-members. The Japan-Singapore PTA contains an article which requires each member to accord treatment granted under the services chapter to a third-country service supplier, provided this supplier is constituted under the laws of either member and provides the service through commercial presence, and has substantive business operations in either of the member countries. What this implies is that there would not be any differential treatment between member and non-member service providers with regard to supply through commercial presence subject to certain terms and conditions being met. This is important as it reflects an open regionalism, permitting third countries to benefit from the services chapter's provisions, if they are operating in a substantive way in one of the member countries. Thus there is scope for extension of bilateral preferences to third country suppliers. However, this does not appear to be a common provision across PTAs.

\subsubsection{Inferences from an analysis of key disciplines}

Although this is a small sample, the above analysis of the content of some key, as well as additional, provisions contained in the services text of these agreements provides some interesting insights regarding 
the scope, intent, and value addition seen in these PTAs. Some of the main inferences drawn from this analysis are highlighted below.

- Often the services disciplines in the PTAs are more loosely worded and more ambiguous than the GATS, even though one would expect PTAs to go beyond the GATS and to be more specific and detailed in their key provisions. They may also be more restrictive than the GATS in that they include additional clauses which provide scope for retaining or introducing limitations or provide some flexibility to allow members to not fulfil certain obligations which are otherwise mandated in the GATS text.

- $\quad$ There is considerable benchmarking of the PTA services disciplines to those found in the GATS. There is also explicit linking of some PTA provisions to future developments in GATS disciplines in some unfinished areas such as domestic regulation, subsidies, safeguards, and government procurement.

- $\quad$ The few areas where there is most deviation in wording or where additional detail or specificity is present in the PTAs (often supplemented with additional coverage under separate chapters) is on issues such as qualification and licensing procedures, recognition, financial services, government services, and government procurement.

- $\quad$ The PTAs tend to be more cognizant than the GATS of federal and sub-federal application or carve-out of measures, by highlighting the different levels of government in the context of several services provisions, in addition to the initial reference excluding services provided in the exercise of governmental authority at all levels of government from the scope of the services text.

- $\quad$ By and large, the PTAs are not specific about extending preferences between the members to third parties or providing non-members scope to obtain similar treatment. Thus, open regionalism is not a feature of most PTAs.

- $\quad$ The PTAs do not go beyond the GATS with regard to institutional frameworks and capacity building. While some do contain provisions calling for such mechanisms to be developed or for capacity building through cooperation, nothing concrete is outlined. There is intent, but no formal development of guidelines and operating procedures in the PTAs.

- Issues which are sensitive under the GATS are also sensitive under the PTAs and thus either carved out or dealt with in separate chapters.

- There is some recognition of the cross-cutting nature of issues such as investment and government procurement in the PTAs, as evident from the cross-referencing to other chapters or parts of the agreement in certain provisions within the services chapters. This kind of crosslinkage is not present explicitly in the GATS text.

- $\quad$ By and large, the scope of the disciplines is the same as that found in the GATS, excepting some additional provisions which are more intent-based disciplines without much content and detail.

- $\quad$ There are a few identifiable patterns that emerge along the developed-developing country dimension. The South-South PTAs tend to include cooperation-type disciplines whereas these are not found in North-North agreements. Establishment of institutional mechanisms is discussed in North-South and South-South agreements but not in North-North agreements. Thus, capacity 
building and formalization of institutional mechanisms appears to be more of a concern in PTAs involving developing countries than for developed countries, as would be expected.

- There is more of a chapter-based coverage of sensitive issues in North-North than in NorthSouth agreements.

- Issues of recognition and qualification appear to be more important in North-South than in North-North agreements, probably reflecting the export interest of developing countries in the movement of natural persons and developed country sensitivities in this mode.

Overall, the PTAs do not seem to go beyond the GATS with regard to rule making. They are forward looking only to the extent that they anticipate developments in the GATS negotiations. Specificity and detail are often lacking and there is little discussion of concrete operating structures and procedures.

\subsection{Content of important chapters and annexes: some insights}

As highlighted earlier, several issues are covered under separate chapters and annexes. The following discussion examines the scope and intent of the provisions in these chapters and compares these to annexes on similar issues under the GATS. It also tries to find out whether and in what manner the nature of the countries involved in a PTA influences the nature of these chapters and annexes. The discussion also highlights additional areas which are covered by the PTAs through chapters that are not found in the GATS, and once again whether this added scope is related to the nature of the countries involved in the agreement.

\subsubsection{Investment}

Almost all the PTAs have a chapter on investment. This is the area where the texts are the most detailed with the scope, definitions, and measures described extensively. There are numerous provisions in the investment chapters. These provisions fall into three categories, (i) those pertaining to treatment of investors from member countries of the agreement and terms and conditions to be accorded to them; (ii) circumstances when exceptions or derogations to the terms and conditions are justified; (iii) judicial, administrative, and institutional requirements and procedures which would enable member countries to resolve investment-related disputes and ensure implementation of the investment-related provisions in these agreements. The first set of provisions includes disciplines such as minimum standards of treatment, national treatment, repatriation, and expropriation. The second includes disciplines such as restrictions to safeguard the balance of payments, denial of benefits, measures in the public interest, and general as well as security exceptions. The third includes disciplines such as disclosure of information, special formalities and information requirements, transparency, review of commitments, investment disputes, and on the entry into force and operation of the agreement. A few PTAs also include a provision to establish a subcommittee on investment for reviewing the implementation and operation of the investment chapter, although by and large there is not much reference to institutional issues other than the arbitration-related aspect of investor disputes.

The detail is greatest on issues of scope and application, such as what is covered by the investment chapter provisions, which kinds of investors are covered, what kinds of transfers would be covered by the provisions on repatriation, what kinds of exceptions can be taken in the case of expropriation, under what conditions members can invoke restrictions to safeguard their interests, and what the procedures would be for resolving investment disputes in terms of the obligations of the parties and the arbitration and institutional frameworks. 
A distinction can be made with regard to the agreements involving developed country partners. In such cases, the investment chapter is particularly detailed with additional annexes on certain provisions such as expropriation and investor-state dispute settlement. The developed country agreements also make an important departure by linking the investment provisions to environment, labour, and movement of natural persons. The Japan-Philippines agreement for instance, notes that parties would not encourage investments by investors of the other party by relaxing environmental or labour regulations, and if such derogations are made, then consultations can be sought with the other party. The JPEPA notes specifically what is meant by "labour laws" in this context. The US-Korea agreement similarly contains a clause on investment and the environment, but here the provision is weaker and merely states that the investment activity would be undertaken in a manner that is sensitive to environmental concerns. The latter agreement also contains provisions linking investment to management, noting that neither party can impose nationality conditions for appointment to senior management positions, while it also states that the members to the agreement can require the majority of the board of directors of an enterprise covered by the investment provisions to be of a particular nationality. Such a clause is also found in the India-Korea and India-Singapore agreements. Hence, there is clear recognition of the links between investment and other parts of the agreement in the North-South agreements.

As investment is perhaps the most important mode of supply in services trade, the elaboration of important provisions on investment is significant and indicates that the PTAs could potentially help evolve investment disciplines which can shape the GATS as well as WTO architecture on this issue. The investment chapters further highlight the cross-cutting nature of disciplines in this area and thus indicate the cross-linkages between services investment and other sectors subject to investment disciplines.

\subsubsection{Movement of Natural Persons}

Compared to the GATS, the PTAs go further in evolving disciplines concerning the movement of natural persons (MNP). They provide greater detail on the scope of the MNP provisions, explicitly noting the different categories of natural persons and what they cover, and also by clearly linking MNP to other regulatory issues by including additional provisions within the chapter on MNP. This is in contrast to the GATS Annex on MNP which is quite ambiguous. The only detail that is present in the GATS Annex regarding the scope of MNP is that the agreement excludes citizenship, residency, or employment on a permanent basis from the scope of the measures applying to natural persons.

The three PTAs involving India contain the most detailed chapters on MNP. They outline in detail the definition of the different categories of natural persons, i.e., contractual service suppliers, business visitors, independent professionals, and intracorporate transferees. The three agreements with India also lay down the terms and conditions for entry and stay of these different categories, such as specifying the period for which entry would be granted for a single visit and the maximum period of stay allowed, exempting natural persons from making social security contributions in the other country, specifying the documentation and administrative requirements for different kinds of natural persons, and even outlining the conditions applicable to spouses and dependants. The India-Korea agreement also lists the occupations under the professional category which are covered by the MNP provisions under this agreement. India's interest in accessing partner country markets through mode 4 is evident from the kind of substantive discussion present in the MNP chapter in all its agreements.

A similar approach is found in the JPEPA. The latter also contains provisions regarding the scope and coverage of natural persons, restrictions that may not be imposed, and the requirements and procedures for entry and stay of a natural person. The terms and conditions for temporary entry and stay are not as 
clearly laid down in the JPEPA as they are in the above-mentioned PTAs involving India. An interesting aspect of the MNP chapter of JPEPA, however, is that it includes a provision on mutual recognition, which is identical to the mutual recognition article found in the services chapter of most PTAs and also in the GATS. By incorporating this provision into the MNP chapter, the agreement clearly establishes the link which exists between mutual recognition and MNP. Thus, as in the case of investment, the crosslinkage between this mode and other parts of the agreement is clearly recognized in the PTAs. An interesting feature of the MNP chapter in JPEPA is that in addition to the usual categories of short-term business visitors, intra-corporate transferees (ICTs), and professionals working on contracts, there is an additional category of investors and one for nurses or certified careworkers, reflecting the significance of these categories to the two parties.

The US-Korea FTA likewise incorporates many of the issues relating to MNP in a separate annex to its chapter on cross-border supply of services. There is an annex on professional services which calls for the establishment of a Professional Services Working Group to exchange information on standards and criteria for the licensing and certification of professional service suppliers, and to undertake discussions to frame mutual recognition agreements and model procedures for licensing and certification, with a review every three years. It also contains an appendix which specifies three professional services sectors, namely, engineering, architectural, and veterinary services, for mutual recognition and temporary licensing. This annex also notes that information will be provided on standards and criteria for licensing and certification.

Institutional mechanisms are important in the MNP chapters. Like the US-Korea annex which refers to the setting up of a Working Group on Professional Services, the JPEPA includes a provision for establishing a sub-committee on MNP. The functions of this proposed sub-committee, are also outlined. There are also other institutional references in the MNP chapters, such as to provisions regarding regulatory transparency, i.e., providing contact points to provide information and facilitating the exchange of information, as well as articles pertaining to settlement of disputes concerning MNP. However, the PTAs do not further clarify institutional details in terms of operating guidelines, timeframes, and the constitution of the proposed committees or working groups.

Overall, as in the case of investment, the PTAs go further than the GATS in developing rules and in defining the scope of measures affecting MNP. Moreover, it is in the North-South PTAs involving potential supplier countries such as India and the Philippines, where such chapters tend to be more substantive in nature, which clearly reflect the interest on the part of member countries in trading through this mode of supply and likely sensitivities to imports through this mode on the other side.

\subsubsection{Government Procurement}

As highlighted earlier, this discipline is not present in most of the PTAs under discussion. Furthermore, only three of the PTAs (US-Korea, Japan-Philippines, and Japan-Singapore) in this sample have chapters on government procurement, clearly indicating the sensitive nature of this issue. However, the PTAs which do cover government procurement in some detail move considerably beyond the equivalent GATS provision, although there is also considerable variation across the PTAs which include a chapter on this subject, in terms of the content, coverage, and institutional details.

The JPEPA includes the basic principles of government procurement, such as according national treatment, ensuring transparency of measures, fair and effective implementation, and consistency of measures used by the parties with international principles. An important element of this chapter is the institutional dimension of future negotiations on this subject, with the establishment of a sub-committee with specified functions and timeframes (though not very specific or detailed). Thus there is a progressive 
nature to this chapter, with negotiations and development of institutional mechanisms in future, while the focus remains on the governing principles that would guide the use of government procurement policies. In contrast to the JPEPA, the US-Korea FTA contains a very elaborate government procurement chapter, which not only outlines scope and coverage and general principles in the use of such policies, but also introduces new areas such as use of electronic means, valuation, conditions of participation, digital products, timeframes, and tendering specifications. Construction services are separately addressed in terms of threshold contract value, highlighting the importance of this sector in the US's governmentfunded programmes as well as Korea's competitive construction services sector. The government procurement chapter in the US-Korea FTA goes further by including an annex for different central level government entities in the two countries.

Overall, the extent of detail and reference annexes highlights the importance of this issue for the US in particular, as well as offering an appreciation of the new modalities for government procurement that have emerged. It is also worth noting that while South Korea has a detailed government procurement chapter in its PTA with the US, this is absent in its PTA with India, indicating a difference in negotiating interests, strategies, and bargaining power depending on the partner country.

\subsubsection{Financial Services}

Financial services is an area where again one sees some improvements in rule-making compared to the GATS. Financial services are covered by a separate annex in the GATS. This annex focuses on issues of definition and scope as well as basic regulatory principles such as the flexibility of member countries to apply prudential regulations and to recognize similar measures taken by other member countries. But the annex does not go further than outlining these general principles. The PTAs, while addressing similar regulatory issues, go beyond the GATS with regard to outlining institutional and judicial elements and at times link financial services to other chapters, such as those on investment, cross-border delivery of services, and dispute settlement, recognizing the importance of this sector and its linkages with many other aspects of the agreement.

In the Japan-Singapore PTA there is an annex on financial services, which includes provisions on domestic regulation, recognition, and dispute settlement, along the lines of the GATS. However, there is also a separate provision for "new financial services" and the manner in which these services are provided. These new services would be subject to licensing, institutional and juridical requirements, as other financial services on a non-discriminatory basis. The inclusion of new financial services reflects the forward looking aspect of this annex in recognizing the growing tradability of services and the emergence of new sub-domains within this sector.

The India-Korea PTA similarly reflects anticipation of emerging financial services. Its annex on financial services specifies that the specific commitments undertaken and the principles of non-discrimination, flexibility in applying prudential regulations, and transparency would also apply to new financial services. Moreover, each party is to allow the other party to supply new financial services where it allows its own financial institutions to do so.

The US-Korea FTA is once again the most detailed in this area. The chapter on financial services in this agreement contains provisions for cross-border trade and national treatment of financial services, while giving flexibility to partners to not accord national treatment and to require registration for some crossborder financial services suppliers. The chapter also includes a provision for new financial services, to allow them access while also giving countries the flexibility to determine the institutional and juridical form by which new financial services are supplied and to require authorization (to be granted within a 
reasonable period of time) for their supply. There are also detailed provisions on transparency in terms of providing information on regulations and status of applications, and also a separate provision on selfregulated organizations, a feature that is not found in any of the financial services chapters or annexes. The agreement also calls for a financial services committee to supervise implementation, consultations, dispute settlement and investment disputes in this sector, thus reflecting the importance of developing institutional mechanisms.

In some agreements, financial services are referred to in the context of the investment chapter provisions on dispute settlement mechanisms as well as safeguard measures. For instance, in the JPEPA, the safeguard provision in the investment chapter refers to balance of payments problems created by crossborder capital transactions. It also specifies that prudential measures for financial services can be maintained or introduced in conformity with the provisions of the investment chapter, indicating the cross-cutting nature of the investment provisions as well as the special nature of the financial services sector in terms of its bearing on macroeconomic stability.

One also finds PTAs such as the China-Pakistan agreement where there is no separate annex on financial services and it is specified that the GATS annex in this area (and all other areas where GATS annexes exist) would apply to the PTA, unless otherwise agreed. Moreover, the substantive content of these annexes is specified as being integral to this agreement. Hence, some agreements still use the GATS as their benchmark and there is no further development of disciplines or institutional mechanisms.

\subsubsection{Telecommunications}

The annex on telecommunication services in the GATS, like the financial services annex, lays down various regulatory principles such as those of transparency and provision of access to and use of public telecom transport networks and services. It also outlines permissible conditions and criteria for imposing restrictions regarding such access and use. The PTAs contain several provisions which echo the same principles, such as those of fair competition, transparency, allowing interconnection to public networks, and public availability of procedures and conditions. There are some deviations, however.

The telecom annex in the Japan-Singapore agreement, for instance, allows for asymmetric regulation, with each member being given flexibility to determine the appropriate level of regulations in accordance with its own rules and frameworks, so as to ensure fair competition. It also mentions that universal service obligations are not be viewed as anticompetitive measures so long as measures relating to these are transparent and applied in a non-discriminatory manner. Allocation of scarce resources is to be done in a transparent and non-discriminatory manner, but parties are not required to provide information on such allocation if this is for government purposes. Thus there is some customization of the principles to fit the partners' institutional and regulatory frameworks and discretionary scope is provided to address public policy objectives.

The India-Korea PTA contains a detailed annex on telecom services, which goes deeper than the GATS. While the GATS framework only specifies that negotiations shall be entered into on a voluntary basis aiming for progressive liberalization of trade in telecom transport networks and services, the PTA annex calls for integrated liberalization. Several aspects of this annex are different from the telecom annex found in the GATS. For example, the PTA annex excludes cable or broadcast distribution of radio or TV programming, reflecting the sensitivities associated with audiovisual services and the treatment of this area in a separate chapter of this agreement. Some additional provisions in this chapter relate to providing reasonable and non-discriminatory terms and conditions for access to and use of public telecommunication services for movement of information and ensuring the security and confidentiality of 
messages and protecting the privacy of personal data of end-users. There is also a separate section on the conduct of major suppliers which includes articles on access to infrastructure, anti-competitive safeguards, interconnection, resolution of interconnection disputes, role of independent regulatory bodies, and principles for licensing, allocation and use of scarce telecom resources. The dispute and appeal procedures are outlined in some detail in the agreement. It is interesting that the PTA also makes note of the precedence of the provisions of the telecom services chapter over other chapters in the agreement if there is any inconsistency in provisions. Thus, the regulatory principles of the telecom services chapter prevail; this would potentially be most relevant in cross-cutting areas such as dispute resolution, transparency, and investment.

Overall, a comparison of the PTA chapters on telecom services with the GATS annex on telecom services reveals that while the broad principles of transparency and non-discrimination continue to hold in the PTAs, the latter tend to be more detailed, better defined in terms of the scope of their provisions, and also more precise on matters such as resolution of disputes or conditions when access and use of public telecom services networks can be restricted in the public or private interest. There is, however, relatively less elaboration or progress on the institutional side as none of the PTA chapters provide detail on institutional and administrative issues.

\subsubsection{Other issues}

As highlighted in Table 5 earlier, several of the selected PTAs contain chapters on new issues such as ecommerce, information and communication technology, and audiovisual services. One area where there is notable progress relative to the GATS is in e-commerce. There is considerable detail on scope, definitions, and principles guiding the application of measures in this area. The India-Singapore agreement and the US-Korea agreement are good examples in this regard.

The chapters on e-commerce in both these agreements are quite similar in that they recognize the economic growth and trade opportunities provided by e-commerce, the importance of avoiding barriers to the use and development of this mode of supply, and the applicability of the WTO agreement to measures affecting e-commerce. Issues such as electronic signatures, authentification, online consumer protection, paperless trading, principles on access and use of the Internet for e-commerce, and protection of personal information are covered in the US-Korea PTA. The India-Singapore agreement highlights the importance of national treatment and transparency in the application of measures in this area. Both agreements further make an exception for government procurement and measures affecting broadcasting, cable casting, and video-on-demand, again reflecting the sensitivities associated with the issues of government procurement and audiovisual services.

The other area where there is some advancement relative to the GATS is in audiovisual services. Some of the PTAs contain a separate chapter on audiovisual services. The India-Korea CEPA contains a short chapter on audiovisual co-production, which covers films, videos, broadcasting, animation, and digital devices and other forms of distribution, including new and emerging ones. While there is little substantive content in terms of concrete regulatory principles and mechanisms laid down and the focus is more on scope and intent, this chapter does identify this sector as important for intensifying cultural and economic relations and the principle of national treatment for any co-production in terms of benefits and 
government support provided, in line with the rules and regulations of each member. The chapter also calls for discussions between competent authorities in the two countries. ${ }^{8}$

Some PTAs also contain cooperation chapters which specifically note the need for facilitating cooperation and information exchange as well as capacity building in areas such as higher education, energy and environment, science and technology, human resource development, tourism, and transport services. The need for cooperation in financial services is also highlighted in the PTAs involving Japan, with reference to capital markets, prudential regulations, and the setting up of working groups. The India-Korea PTA is a case in point, which covers a wide range of issues and services where cooperation is to be undertaken. However, on the whole, the cooperation chapters tend to be general and are not particularly detailed. They are mostly indicative of their recognition of certain issues or sectors as important for expanding bilateral relations and read more as general expressions of intent to hold future discussions and to engage in capacity building efforts.

\subsubsection{Inferences from an analysis of key chapters and annexes}

Several important insights can be obtained from a review of the scope and substantive content of the chapters and annexes on specific sectors and issues in the selected PTAs. There are several cross-cutting issues on which the PTAs move significantly beyond the GATS. There are others where there is some progress in terms of outlining the way forward but without complementary information on mechanisms and procedures.

- The area where most progress is visible is investment, particularly with regard to terms and conditions, investors' rights, and arbitration issues. Investment is also related to other issues such as environment and labour and to important sectors such as financial services. These disciplines provide a possible reference for GATS negotiations on investment-related matters.

- There is also notable progress in the area of MNP relative to the GATS. Again, the extent of detail, specification of various categories of service suppliers, albeit based on the GATS discussions in this area, but also customized to suit the interests of PTA partner countries, with listing of professional categories and occupations of interest, provides a useful reference for the GATS negotiations in this area.

- There has perhaps been less movement in areas such as government procurement than for investment and MNP issues. However, where government procurement is covered through additional chapters, the provision of details on institutional requirements and the outlining of the scope of such measures is a step forward from the GATS's rather loosely worded, embryonic provision on government procurement.

- In their treatment of specific services such as financial or telecom services, the PTAs largely benchmark themselves to the GATS by upholding the same regulatory principles of transparency

\footnotetext{
${ }^{8}$ The US-Korea agreement also has an annex on express delivery services, which asks the parties to maintain the existing level of market openness, to prevent revenues derived from monopoly postal services from being used to confer an advantage to domestic or other competitors' suppliers of express delivery services. However, the two sides can adopt or maintain measures outside the scope of the chapter or measures in their schedule pertaining to transport services.
} 
and non-discrimination as well as providing some flexibilities for imposing regulations that meet certain kinds of objectives. However, once again they go further than the GATS in outlining institutional and judicial processes and requirements, by highlighting linkages to other parts of the agreements, and also introducing references to new and emerging segments into the ambit of future negotiations in these sectors.

- The PTAs also cover a wider range of issues and sectors, many of an emergent nature, through their additional chapters and annexes. By incorporating areas such as energy, the environment, ICT, and e-commerce, they clearly reflect a more forward looking and dynamic approach, with obvious implications for the scope of services negotiations under these agreements.

\section{Scope and depth of commitments in Asia's services PTAs}

The preceding discussion has highlighted the areas in which the PTA disciplines on services have gone beyond the GATS and where they have relied on the GATS as a reference document, and have almost identical content. The following discussion examines how much further countries have gone in their PTAs in terms of undertaking liberalization commitments in services relative to their services commitments under the GATS. The analysis looks at both the scope and depth of the commitments undertaken in terms of the sectoral and subsectoral coverage as well as the modal profile of the commitments undertaken in the PTAs vis-à-vis those under the GATS. Such an analysis is possible given that all 6 PTAs where there are scheduled commitments adopt a positive list approach. ${ }^{9}$ The analysis also tries to identify patterns with regard to the nature of liberalization undertaken for specific services and modes of supply and looks at patterns with regard to the level of development, the type of PTA (developed-developed, developing-developing, and developed-developing) and the countries concerned. An attempt is also made to assess if countries have indicated a greater willingness to liberalize over time as reflected in the nature and scope of the commitments they have undertaken in recent versus earlier PTAs.

\subsection{Sectoral and sub-sectoral coverage}

The first level of analysis is to compare the number of service sectors scheduled by countries for liberalization under their PTAs with the number of service sectors they have scheduled under the GATS. This comparison should provide a broad indication of their willingness to negotiate under PTAs vis-à-vis the GATS. Table 7 summarizes the number of services scheduled by each of the countries in the sample of agreements under consideration in this paper, in the GATS and in their PTAs.

Table $7 \quad$ Number of service sectors scheduled in the GATS and in selected PTAs

\begin{tabular}{|c|c|c|c|c|c|c|c|}
\hline Country & GATS & $\begin{array}{l}\text { India- } \\
\text { Korea }\end{array}$ & $\begin{array}{l}\text { India-- } \\
\text { Singapore }\end{array}$ & $\begin{array}{l}\text { Japan-- } \\
\text { Singapore }\end{array}$ & $\begin{array}{l}\text { Japan- } \\
\text { Philippines }\end{array}$ & $\begin{array}{l}\text { China- } \\
\text { ASEAN }\end{array}$ & $\begin{array}{l}\text { China- } \\
\text { Pakistan }\end{array}$ \\
\hline
\end{tabular}

\footnotetext{
${ }^{9}$ The PTAs under consideration for analysing the scope and depth of services liberalization commitments include the India-Singapore, India-Korea, Japan-Philippines, Japan-Singapore, China-ASEAN, and China-Pakistan agreements. The US-Korea and India-Sri Lanka PTAs do not have scheduled commitments as of date and are thus excluded from this analysis.
} 


\begin{tabular}{|c|c|c|c|c|c|c|c|}
\hline Pakistan & 6 & & & & & & 11 \\
\hline India & 6 & 11 & 9 & & & & \\
\hline Philippines & 4 & & & & 9 & 5 & \\
\hline Indonesia & 1 & & & & & 6 & \\
\hline China & 9 & & & & & 5 & 11 \\
\hline Thailand & 10 & & & & & 4 & \\
\hline Malaysia & 8 & & & & & 8 & \\
\hline Korea & 8 & 10 & & & & & \\
\hline Singapore & 6 & & 11 & 11 & & 8 & \\
\hline Japan & 10 & & & 11 & 10 & & \\
\hline
\end{tabular}

Source: Based on an examination of the countries' GATS schedules and their commitments under the selected PTAs

It is evident from Table 7 that in most cases countries have scheduled a larger number of services sectors in their PTAs than under the GATS. In several cases, the number of services scheduled has increased several fold to cover all 11 possible service sectors (excluding other services). For instance, both India and Pakistan have increased the number of service sectors scheduled from 6 under the GATS to 11 under the China-Pakistan PTA and the India-Korea PTA, respectively. The Philippines has increased its scheduling coverage from 4 under the GATS to 9 under the JPEPA. Overall, countries have moved towards near universal coverage of service sectors in their scheduling process.

The China-ASEAN PTA, however, presents a mixed picture. While some countries such as Singapore and Indonesia have increased the number of services scheduled under this PTA vis-à-vis their sectoral coverage under the GATS, some, such as Thailand, have significantly reduced the scope of their commitments. Even China has scheduled fewer sectors under this PTA than under the China-Pakistan PTA. Certain countries, for example, Singapore, have shown less willingness to negotiate sectors in the China-ASEAN PTA than in their other PTAs. Hence, under the China-ASEAN PTA, countries have shown less willingness on both sides to schedule sectors for negotiations, not only compared to the GATS but also compared to other agreements they have signed. The latter is also to some extent reflected in the much weaker nature of provisions in this agreement, as highlighted in the preceding section. But for all the other PTAs, countries have improved the scope of liberalization commitments.

An examination of the sub-sectoral scope for commitments similarly highlights the willingness of countries to negotiate a larger number of service activities within certain individual service sectors under the PTAs compared to that under the GATS. This applies to almost all the countries covered in this sample of agreements and holds across almost all the PTAs, excepting the China-ASEAN agreement. The latter is reflected in Tables $8 \mathrm{a}$ to $8 \mathrm{j}$, which provide an overview of the number of subsectors in which commitments have been undertaken by 10 of the countries under consideration in this paper (all excluding Sri Lanka and the US) across 11 service sectors classified under the GATS (excluding the other services sector).

Table 8a Number of subsectors in which commitments have been undertaken by India in the GATS and in selected PTAs

\begin{tabular}{|c|l|r|r|r|}
\hline Country & \multicolumn{1}{|c|}{ Service Sector } & GATS & $\begin{array}{c}\text { India- } \\
\text { Singapore }\end{array}$ & $\begin{array}{l}\text { India- } \\
\text { Korea }\end{array}$ \\
\hline India & Business & 8 & 39 & 34 \\
\hline
\end{tabular}




\begin{tabular}{|l|r|rr|} 
Communication & 11 & 14 & 16 \\
\hline Distribution & 0 & 2 & 2 \\
\hline Construction & 1 & 8 & 2 \\
\hline Transport & 0 & 10 & 11 \\
\hline Financial & 10 & 18 & 20 \\
\hline Tourism & 2 & 2 & 3 \\
\hline Education & 0 & 0 & 1 \\
\hline Environment & 0 & 0 & 2 \\
\hline Health & 1 & 1 & 1 \\
\hline Recreational & 0 & 0 & 2 \\
\hline
\end{tabular}

Source: Author's calculations based on country's GATS commitments available at the WTO website (www.wto.org) and text documents of country's PTAs.

Table $8 \mathrm{~b} \quad$ Number of subsectors in which commitments have been undertaken by Korea in the GATS and in selected PTAs

\begin{tabular}{|l|l|r|r|}
\hline Country & \multicolumn{1}{|c|}{ Service Sector } & \multicolumn{1}{c|}{ GATS } & \multicolumn{1}{c|}{$\begin{array}{l}\text { India- } \\
\text { Korea }\end{array}$} \\
\hline \multirow{5}{*}{ Korea } & Business & 35 & 50 \\
\cline { 2 - 4 } & Communication & 26 & 19 \\
\cline { 2 - 4 } & Distribution & 7 & 4 \\
\cline { 2 - 4 } & Construction & 7 & 1 \\
\cline { 2 - 4 } & Transport & 16 & 22 \\
\cline { 2 - 4 } & Financial & 22 & 24 \\
\cline { 2 - 4 } & Tourism & 4 & 5 \\
\cline { 2 - 4 } & Education & 0 & 2 \\
\cline { 2 - 4 } & Environment & 6 & 4 \\
\cline { 2 - 4 } & Health & 0 & 0 \\
\cline { 2 - 4 } & Recreational & 0 & 2 \\
\hline
\end{tabular}

Source: Author's calculations based on country's GATS commitments available at the WTO website (www.wto.org) and text documents of country's PTAs.

Table 8c Number of subsectors in which commitments have been undertaken by Singapore in the GATS and in selected PTAs

\begin{tabular}{|l|l|r|r|r|r|}
\hline Country & \multicolumn{1}{|c|}{ Service Sector } & GATS & $\begin{array}{c}\text { Japan- } \\
\text { Singapore }\end{array}$ & $\begin{array}{c}\text { India- } \\
\text { Singapore }\end{array}$ & $\begin{array}{c}\text { China- } \\
\text { ASEAN }\end{array}$ \\
\hline Singapore & Business & 23 & 55 & 49 & 17 \\
\cline { 2 - 6 } & Communication & 5 & 14 & 8 & 5 \\
\cline { 2 - 6 } & Distribution & 0 & 5 & 7 & 4 \\
\cline { 2 - 6 } & Construction & 0 & 8 & 8 & 0 \\
\cline { 2 - 6 } & Transport & 2 & 34 & 31 & 8 \\
\cline { 2 - 6 } & Financial & 17 & 17 & 17 & 17 \\
\cline { 2 - 6 } & Tourism & 3 & 7 & 6 & 0 \\
\cline { 2 - 7 } & Education & 0 & 4 & 4 & 0 \\
\hline
\end{tabular}




\begin{tabular}{|l|l|l|l|l|} 
Environment & 0 & 3 & 2 & 3 \\
\hline Health & 0 & 7 & 5 & 6 \\
\hline Recreational & 0 & 8 & 7 & 4 \\
\hline
\end{tabular}

Source: Author's calculations based on country's GATS commitments available at the WTO website (www.wto.org) and text documents of country's PTAs.

Table $8 \mathrm{~d} \quad$ Number of subsectors in which commitments have been undertaken by China in the GATS and in selected PTAs

\begin{tabular}{|l|l|r|r|r|}
\hline Country & \multicolumn{1}{|c|}{ Service Sector } & GATS & $\begin{array}{c}\text { China- } \\
\text { ASEAN }\end{array}$ & $\begin{array}{c}\text { China- } \\
\text { Pakistan }\end{array}$ \\
\hline \multirow{7}{*}{ China } & Business & 22 & 14 & 31 \\
\cline { 2 - 5 } & Communication & 11 & 0 & 13 \\
\cline { 2 - 5 } & Distribution & 5 & 0 & 5 \\
\cline { 2 - 5 } & Construction & 5 & 8 & 8 \\
\cline { 2 - 5 } & Transport & 12 & 8 & 15 \\
\cline { 2 - 5 } & Financial & 13 & 0 & 19 \\
\cline { 2 - 5 } & Tourism & 2 & 0 & 2 \\
\cline { 2 - 5 } & Education & 5 & 0 & 5 \\
\cline { 2 - 6 } & Environment & 7 & 7 & 7 \\
\cline { 2 - 6 } & Health & 0 & 0 & 1 \\
\cline { 2 - 6 } & Recreational & 0 & 1 & 1 \\
\hline
\end{tabular}

Source: Author's calculations based on country's GATS commitments available at the WTO website (www.wto.org) and text documents of country's PTAs.

Table 8e Number of subsectors in which commitments have been undertaken by Japan in the GATS and in selected PTAs

\begin{tabular}{|l|l|r|r|r|}
\hline \multirow{2}{*}{ Country } & \multicolumn{1}{|c|}{ Service Sector } & \multicolumn{1}{c|}{ GATS } & JPEPA & $\begin{array}{c}\text { Japan- } \\
\text { Singapore }\end{array}$ \\
\hline \multirow{7}{*}{ Japan } & Business & 28 & 65 & 47 \\
\cline { 2 - 5 } & Communication & 15 & 21 & 20 \\
\cline { 2 - 5 } & Distribution & 7 & 8 & 10 \\
\cline { 2 - 5 } & Construction & 8 & 5 & 16 \\
\cline { 2 - 5 } & Transport & 13 & 34 & 33 \\
\cline { 2 - 5 } & Financial & 0 & 16 & 0 \\
\cline { 2 - 5 } & Tourism & 5 & 4 & 4 \\
\cline { 2 - 5 } & Education & 4 & 6 & 7 \\
\cline { 2 - 5 } & Environment & 4 & 4 & 4 \\
\cline { 2 - 6 } & Health & 4 & 5 & 4 \\
\cline { 2 - 6 } & Recreational & 4 & 8 & 8 \\
\hline
\end{tabular}

Source: Author's calculations based on country's GATS commitments available at the WTO website (www.wto.org) and text documents of country's PTAs. 
Table $8 \mathrm{f} \quad$ Number of subsectors in which commitments have been undertaken by the Philippines in the GATS and in selected PTAs

\begin{tabular}{|c|l|r|r|r|}
\hline \multirow{2}{*}{ Country } & \multicolumn{1}{|c|}{ Service Sector } & \multicolumn{1}{c|}{ GATS } & \multicolumn{1}{c|}{ JPEPA } & \multicolumn{1}{c|}{$\begin{array}{c}\text { China- } \\
\text { ASEAN }\end{array}$} \\
\hline \multirow{5}{*}{ Philippines } & Business & 0 & 18 & 4 \\
\cline { 2 - 5 } & Communication & 5 & 21 & 13 \\
\cline { 2 - 5 } & Distribution & 0 & 1 & 0 \\
\cline { 2 - 5 } & Construction & 0 & 0 & 1 \\
\cline { 2 - 5 } & Transport & 14 & 21 & 0 \\
\cline { 2 - 5 } & Financial & 35 & 17 & 0 \\
\cline { 2 - 5 } & Tourism & 4 & 4 & 4 \\
\cline { 2 - 5 } & Education & 0 & 6 & 0 \\
\cline { 2 - 5 } & Environment & 0 & 1 & 1 \\
\cline { 2 - 5 } & Health & 0 & 0 & 0 \\
\cline { 2 - 5 } & Recreational & 0 & 1 & 0 \\
\hline
\end{tabular}

Source: Author's calculations based on country's GATS commitments available at the WTO website (www.wto.org) and text documents of country's PTAs.

Table 8g Number of subsectors in which commitments have been undertaken by Indonesia in the GATS and in selected PTAs

\begin{tabular}{|l|l|r|r|}
\hline Country & \multicolumn{1}{|c|}{ Service Sector } & GATS & \multicolumn{1}{c|}{$\begin{array}{c}\text { China- } \\
\text { ASEAN }\end{array}$} \\
\hline \multirow{5}{*}{ Indonesia } & Business & 13 & 0 \\
\cline { 2 - 4 } & Communication & 26 & 0 \\
\cline { 2 - 4 } & Distribution & 0 & 0 \\
\cline { 2 - 4 } & Construction & 6 & 11 \\
\cline { 2 - 4 } & Transport & 2 & 0 \\
\cline { 2 - 4 } & Financial & 23 & 0 \\
\cline { 2 - 4 } & Tourism & 3 & 6 \\
\cline { 2 - 4 } & Education & 0 & 0 \\
\cline { 2 - 4 } & Environment & 0 & 0 \\
\cline { 2 - 4 } & Health & 0 & 0 \\
\cline { 2 - 4 } & Recreational & 0 & 0 \\
\hline
\end{tabular}

Source: Author's calculations based on country's GATS commitments available at the WTO website (www.wto.org) and text documents of country's PTAs. 
Table $8 \mathrm{~h} \quad$ Number of subsectors in which commitments have been undertaken by Malaysia in the GATS and in selected PTAs

\begin{tabular}{|l|l|r|r|}
\hline \multirow{1}{*}{ Country } & \multicolumn{1}{|c|}{ Service Sector } & \multicolumn{1}{|c|}{ GATS } & $\begin{array}{c}\text { China- } \\
\text { ASEAN }\end{array}$ \\
\hline \multirow{5}{*}{ Malaysia } & Business & 29 & 7 \\
\cline { 2 - 4 } & Communication & 5 & 2 \\
\cline { 2 - 4 } & Distribution & 0 & 0 \\
\cline { 2 - 4 } & Construction & 7 & 7 \\
\cline { 2 - 4 } & Transport & 3 & 3 \\
\cline { 2 - 4 } & Financial & 23 & 2 \\
\cline { 2 - 4 } & Tourism & 2 & 2 \\
\cline { 2 - 4 } & Education & 0 & 1 \\
\cline { 2 - 4 } & Environment & 0 & 0 \\
\cline { 2 - 4 } & Health & 1 & 1 \\
\cline { 2 - 4 } & Recreational & 2 & 0 \\
\hline
\end{tabular}

Source: Author's calculations based on country's GATS commitment available at the WTO website (www.wto.org) and text documents of country's PTAs

Table $8 \mathrm{i} \quad$ Number of subsectors in which commitments have been undertaken by Thailand in the GATS and in selected PTAs

\begin{tabular}{|l|l|r|r|}
\hline Country & \multicolumn{1}{|c|}{ Service Sector } & \multicolumn{1}{|c|}{ GATS } & \multicolumn{1}{c|}{$\begin{array}{c}\text { China- } \\
\text { ASEAN }\end{array}$} \\
\hline \multirow{5}{*}{ Thailand } & Business & 23 & 4 \\
\cline { 2 - 4 } & Communication & 5 & 0 \\
\cline { 2 - 4 } & Distribution & 1 & 0 \\
\cline { 2 - 4 } & Construction & 3 & 0 \\
\cline { 2 - 4 } & Transport & 12 & 1 \\
\cline { 2 - 4 } & Financial & 15 & 0 \\
\cline { 2 - 4 } & Tourism & 5 & 5 \\
\cline { 2 - 4 } & Education & 3 & 4 \\
\cline { 2 - 4 } & Environment & 7 & 0 \\
\cline { 2 - 4 } & Health & 0 & 0 \\
\cline { 2 - 4 } & Recreational & 2 & 0 \\
\hline
\end{tabular}

Source: Author's calculations based on country's GATS commitments available at the WTO website (www.wto.org) and text documents of country's PTAs. 
Table $8 \mathrm{j} \quad$ Number of subsectors in which commitments have been undertaken by Pakistan in the GATS and in selected PTAs

\begin{tabular}{|l|l|r|r|}
\hline Country & \multicolumn{1}{|c|}{ Service Sector } & \multicolumn{1}{|c|}{ GATS } & \multicolumn{1}{c|}{$\begin{array}{c}\text { China- } \\
\text { Pakistan }\end{array}$} \\
\hline \multirow{5}{*}{ Pakistan } & Business & 10 & 23 \\
\cline { 2 - 4 } & Communication & 11 & 15 \\
\cline { 2 - 4 } & Distribution & 0 & 3 \\
\cline { 2 - 4 } & Construction & 2 & 6 \\
\cline { 2 - 4 } & Transport & 0 & 15 \\
\cline { 2 - 4 } & Financial & 16 & 16 \\
\cline { 2 - 4 } & Tourism & 2 & 4 \\
\cline { 2 - 4 } & Education & 0 & 3 \\
\cline { 2 - 4 } & Environment & 0 & 5 \\
\cline { 2 - 4 } & Health & 2 & 1 \\
\cline { 2 - 4 } & Recreational & 0 & 5 \\
\hline
\end{tabular}

Source: Author's calculations based on country's GATS commitments available at the WTO website (www.wto.org) and text documents of country's PTAs.

Tables $8 \mathrm{a}$ to $8 \mathrm{j}$ also reveal some interesting patterns across different services. For instance, business services have seen the greatest increase in the number of subsectors in which commitments have been made for almost all countries and across almost all PTAs (excepting the China-ASEAN PTA). The number of business service subsectors committed by India has increased from 8 under the GATS to 39 under the India-Singapore agreement and to 34 under the India-Korea agreement. The Philippines has likewise increased its subsectoral commitments in this sector from 0 under the GATS to 18 under JPEPA and Pakistan has increased the scope of its business services commitments from 10 under the GATS to 23 under the China-Pakistan agreement. Even developed countries such as Japan, Singapore, and Korea have significantly increased the number of business service activities for which commitments have been made under their PTAs relative to their commitments under the GATS, from 35 to 50 for Korea under the India-Korea agreement, from 23 to 55 and 49 for Singapore under the Japan-Singapore and IndiaSingapore agreements, respectively, and from 28 to 65 and 47 for Japan under the Japan-Singapore agreement and JPEPA, respectively. For sectors other than business services there is no clearly identifiable sector where one sees a consistent improvement in the scope of subsectoral commitments. In some cases communication and transport services have seen improvements in scope, albeit to varying degrees.

In general, the developed countries in the sample tend to show a greater willingness to commit in more service activities, the number of subsectors in which commitments have been made also being much greater than for developing countries. Among the developing countries in this sample, India stands out, as the scope of its subsectoral commitments has increased significantly in both the India-Korea and IndiaSingapore agreements and this improvement is seen across almost all services. While the Philippines and Pakistan have also shown willingness to commit more services under their PTAs, the number of service subsectors in which they have made commitments tends to be much lower than that for India, across nearly all services. India's greater proactiveness in scheduling more service sectors and subsectors probably reflects its keen interest in negotiating services given its comparative advantage in the service sector. One also finds that country-specific considerations are reflected in the scope of commitments. For example, India has made commitments in 8 subsectors under construction services in its agreement with 
Singapore, up from 1 under the GATS. However, it has committed only 2 subsectors under its agreement with Korea, probably reflecting South Korea's competitiveness in construction services and the greater sensitivity of this sector in the context of India's negotiations with Korea. Thus, sector and countryspecific concerns are evident in the subsectoral pattern of commitments. Further, services such as health, education, environment, and distribution, where there is less scheduling under the GATS, exhibit a similar pattern under the PTAs. There is at best a marginal increase in the number of subsectors where commitments have been made in such services, indicating that these remain sensitive on public policy and social grounds even under PTAs. It is also interesting to note that some services, such as financial services, have also seen a decrease in the number of subsectors in which commitments have been made by almost all the developing countries. This is particularly so for the ASEAN countries which have significantly reduced the number of financial services where commitments have been made to zero under the China-ASEAN agreement, possibly reflecting the cautious approach to this sector following the 1997 Asian crisis, and the absence of any separate provisions on financial services under this agreement. ${ }^{10}$

Table 9 summarizes the information presented country-wise in the preceding tables, for four selected services, namely, business, financial, communication, and construction services, by agreement. The reason for presenting the information in this manner is to enable analysis across four dimensions, i.e., to see how the commitment pattern varies: (a) across the four selected services; (b) across the different PTAs; (c) for the same country across its different PTAs, and; (d) between the two partners for a given PTA.

Table 9 Number of subsectors in which commitments have been made in four services under the GATS and in selected PTAs

\begin{tabular}{|c|c|c|c|c|c|c|c|c|c|}
\hline \multirow[t]{2}{*}{ PTA Name } & \multirow{2}{*}{ Country } & \multicolumn{2}{|c|}{$\begin{array}{l}\text { Business } \\
\text { Services }\end{array}$} & \multicolumn{2}{|c|}{$\begin{array}{l}\text { Financial } \\
\text { Services }\end{array}$} & \multicolumn{2}{|c|}{$\begin{array}{c}\text { Communication } \\
\text { Services }\end{array}$} & \multicolumn{2}{|c|}{$\begin{array}{c}\text { Construction } \\
\text { Services }\end{array}$} \\
\hline & & GATS & PTA & GATS & PTA & GATS & PTA & GATS & PTA \\
\hline \multirow{2}{*}{$\begin{array}{c}\text { India-Korea } \\
\text { CEPA }\end{array}$} & India & 8 & 34 & 10 & 20 & 11 & 16 & 1 & 2 \\
\hline & Korea & 35 & 50 & 22 & 24 & 26 & 19 & 7 & 1 \\
\hline \multirow{2}{*}{$\begin{array}{c}\text { India-Singapore } \\
\text { CECA }\end{array}$} & India & 8 & 39 & 10 & 18 & 11 & 14 & 1 & 8 \\
\hline & Singapore & 23 & 49 & 17 & 17 & 5 & 8 & 0 & 8 \\
\hline \multirow{2}{*}{$\begin{array}{c}\text { Japan-Singapore } \\
\text { CECA }\end{array}$} & Japan & 28 & 47 & 0 & 0 & 15 & 20 & 8 & 16 \\
\hline & Singapore & 23 & 55 & 17 & 17 & 5 & 14 & 0 & 8 \\
\hline \multirow{2}{*}{$\begin{array}{c}\text { Japan- } \\
\text { Philippines EPA }\end{array}$} & Japan & 28 & 65 & 0 & 16 & 15 & 21 & 8 & 5 \\
\hline & Philippines & 0 & 18 & 35 & 17 & 5 & 21 & 0 & 0 \\
\hline China-Pakistan & China & 22 & 31 & 13 & 19 & 11 & 13 & 5 & 8 \\
\hline
\end{tabular}

\footnotetext{
${ }^{10}$ It would be worth examining whether the PTAs which have stronger regulatory provisions for the financial services, such as through additional chapters and annexes in this area, also tend to be associated with more subsectors having commitments in this sector, i.e., how the strength of the PTA framework and provisions influences countries' willingness to commit, especially in sensitive areas like financial services.
} 


\begin{tabular}{|c|c|r|r|r|r|r|r|r|r|r|}
\hline FTA & Pakistan & 10 & 23 & 16 & 16 & 11 & 15 & 2 & 6 \\
\hline & China & 22 & 14 & 13 & 0 & 11 & 0 & 5 & 8 \\
\hline \multirow{4}{*}{$\begin{array}{c}\text { China-ASEAN } \\
\text { FTA }\end{array}$} & Indonesia & 13 & 0 & 23 & 0 & 26 & 0 & 6 & 11 \\
\cline { 2 - 10 } & Malaysia & 29 & 7 & 23 & 2 & 5 & 2 & 7 & 7 \\
\cline { 2 - 10 }$y$ & Philippines & 0 & 4 & 35 & 0 & 5 & 13 & 0 & 1 \\
\cline { 2 - 10 }$y$ & Singapore & 23 & 17 & 17 & 17 & 5 & 5 & 0 & 0 \\
\cline { 2 - 11 } & Thailand & 23 & 4 & 15 & 0 & 5 & 0 & 3 & 0 \\
\hline
\end{tabular}

Source: Author's calculations based on country's GATS commitments available at the WTO website (www.wto.org) and text documents of country's PTAs.

Table 9 clearly shows that, with the exception of the China-ASEAN PTA, in general there has been an improvement in the scope of commitments, particularly in business services. The developed countries in this sample are more extensive in the scope of their commitments relative to the developing countries. India has signalled stronger liberalization intent in its PTAs than the other developing countries in this sample. Individual country interests, sensitivities (in particular services), and partner country advantages and specifics seem to play a role in determining how extensive the commitments are and in which services they are made, as countries do not necessarily show a similar willingness to commit across their various PTAs. There is also some backtracking or status quo maintained relative to the GATS in the financial services sector. The China-ASEAN agreement clearly stands out as an aberration with commitments in many fewer subsectors on both sides, perhaps reflecting partner-specific concerns and the fact that this is a weaker agreement in terms of its framework and provisions than the other PTAs under discussion.

While the preceding tables provide a good idea of countries' willingness to negotiate, they only capture the absolute number of services subsectors. However, since the maximum possible number of subsectors varies considerably between different services, one also needs to consider the percentage of total possible subsectors in which commitments have been made in each sector, across the different PTAs. Table 10 provides this overview for the same four selected services.

Table 10 Share of total possible subsectors in which commitments have been made in the GATS and in selected PTAs (\%)

\begin{tabular}{|c|c|c|c|c|c|c|c|c|c|}
\hline \multirow{2}{*}{$\begin{array}{l}\text { PTA } \\
\text { Name }\end{array}$} & \multirow[t]{2}{*}{ Country } & \multicolumn{2}{|c|}{$\begin{array}{l}\text { Business } \\
\text { Services }\end{array}$} & \multicolumn{2}{|c|}{$\begin{array}{c}\text { Financial } \\
\text { Services }\end{array}$} & \multicolumn{2}{|c|}{$\begin{array}{c}\text { Communication } \\
\text { Services }\end{array}$} & \multicolumn{2}{|c|}{$\begin{array}{c}\text { Construction } \\
\text { Services }\end{array}$} \\
\hline & & GATS & PTA & GATS & PTA & GATS & PTA & GATS & PTA \\
\hline \multirow{2}{*}{$\begin{array}{c}\text { India-Korea } \\
\text { CEPA }\end{array}$} & India & 17.39 & 73.91 & 58.82 & 117.65 & 45.83 & 66.67 & 20.00 & 40.00 \\
\hline & Korea & 76.09 & 108.70 & 129.41 & 141.18 & 108.33 & 79.17 & 140.00 & 20.00 \\
\hline \multirow{2}{*}{$\begin{array}{c}\text { India- } \\
\text { Singapore } \\
\text { CECA }\end{array}$} & India & 17.39 & 84.78 & 58.82 & 105.88 & 45.83 & 58.33 & 20.00 & 160.00 \\
\hline & Singapore & 50.00 & 106.52 & 100.00 & 100.00 & 20.83 & 33.33 & 0.00 & 160.00 \\
\hline \multirow{2}{*}{$\begin{array}{c}\text { Japan- } \\
\text { Singapore }\end{array}$} & Japan & 60.87 & 102.17 & 0.00 & 0.00 & 62.50 & 83.33 & 160.00 & 320.00 \\
\hline & Singapore & 50.00 & 119.57 & 100.00 & 100.00 & 20.83 & 58.33 & 0.00 & 160.00 \\
\hline
\end{tabular}




\begin{tabular}{|c|c|c|c|c|c|c|c|c|c|}
\hline CECA & & & & & & & & & \\
\hline \multirow{2}{*}{$\begin{array}{c}\text { Japan- } \\
\text { Philippines } \\
\text { EPA } \\
\end{array}$} & Japan & 60.87 & 141.30 & 0.00 & 94.12 & 62.50 & 87.50 & 160.00 & 100.00 \\
\hline & Philippines & 0.00 & 39.13 & 205.88 & 100.00 & 20.83 & 87.50 & 0.00 & 0.00 \\
\hline \multirow{2}{*}{$\begin{array}{c}\text { China- } \\
\text { Pakistan FTA }\end{array}$} & China & 47.83 & 67.39 & 76.47 & 111.76 & 45.83 & 54.17 & 100.00 & 160.00 \\
\hline & Pakistan & 21.74 & 50.00 & 94.12 & 94.12 & 45.83 & 62.50 & 40.00 & 120.00 \\
\hline \multirow{6}{*}{$\begin{array}{c}\text { China-ASEAN } \\
\text { FTA }\end{array}$} & China & 47.83 & 30.43 & 76.47 & 0.00 & 45.83 & 0.00 & 100.00 & 160.00 \\
\hline & Indonesia & 28.26 & 0.00 & 135.29 & 0.00 & 108.33 & 0.00 & 120.00 & 220.00 \\
\hline & Malaysia & 63.04 & 15.22 & 135.29 & 11.76 & 20.83 & 8.33 & 140.00 & 140.00 \\
\hline & Philippines & 0.00 & 8.70 & 205.88 & 0.00 & 20.83 & 54.17 & 0.00 & 20.00 \\
\hline & Singapore & 50.00 & 36.96 & 100.00 & 100.00 & 20.83 & 20.83 & 0.00 & 0.00 \\
\hline & Thailand & 50.00 & 8.70 & 88.24 & 0.00 & 20.83 & 0.00 & 60.00 & 0.00 \\
\hline
\end{tabular}

Source: Author's calculations based on country's GATS commitments available at the WTO website (www.wto.org) and text documents of country's PTAs.

Note: A share of more than $100 \%$ indicates that the sector has been subclassified in more detail than is given in the GATS sectoral classification list. This is true even in the case of the GATS commitments made by countries where various service activities which have been grouped together under a particular service subsector under the GATS have been listed separately by countries in their commitments.

Table 10 highlights the same pattern as discussed earlier, with the greatest increase in the share of commitments in all possible subsectors being in business services, with a mixed pattern for other services. However, one also finds that a significant percentage of commitments in the feasible set of subsectors has been made under the PTAs across several other services. Moreover, in some PTAs, the share exceeds $100 \%$ indicating the expansion of the sector to include additional subsectors relative to the GATS (even in cases where the share of commitments under the GATS exceeds 100\%). The latter implies that PTAs are often more detailed than the GATS in terms of listing more services sub-categories and explicitly including new services (as also highlighted earlier in the context of new financial services being explicitly mentioned in the services chapters of several agreements). Once again, however, the China-ASEAN agreement clearly shows backtracking relative to the share of services in which commitments were made under the GATS.

\subsection{Correlating scope of liberalization with stage of development}

There is also a clear positive correlation between the level of development of countries and the scope of their sectoral and subsectoral commitments, both under the GATS and under their PTAs. Figures 1 to 4 illustrate this positive relationship. The figures for gross domestic product (GDP) per capita are taken for the year when commitments were undertaken, under the GATS and under the PTAs for each country. The trend line that best fits the actual number of sectors and subsectors in which commitments were made by the sample of countries in the multilateral and bilateral/regional context is positively sloped, indicating that the more advanced countries tend to commit in more sectors and subsectors. 
Figure 1 Number of Sectors in which commitments were made under the GATS and GDP per capita

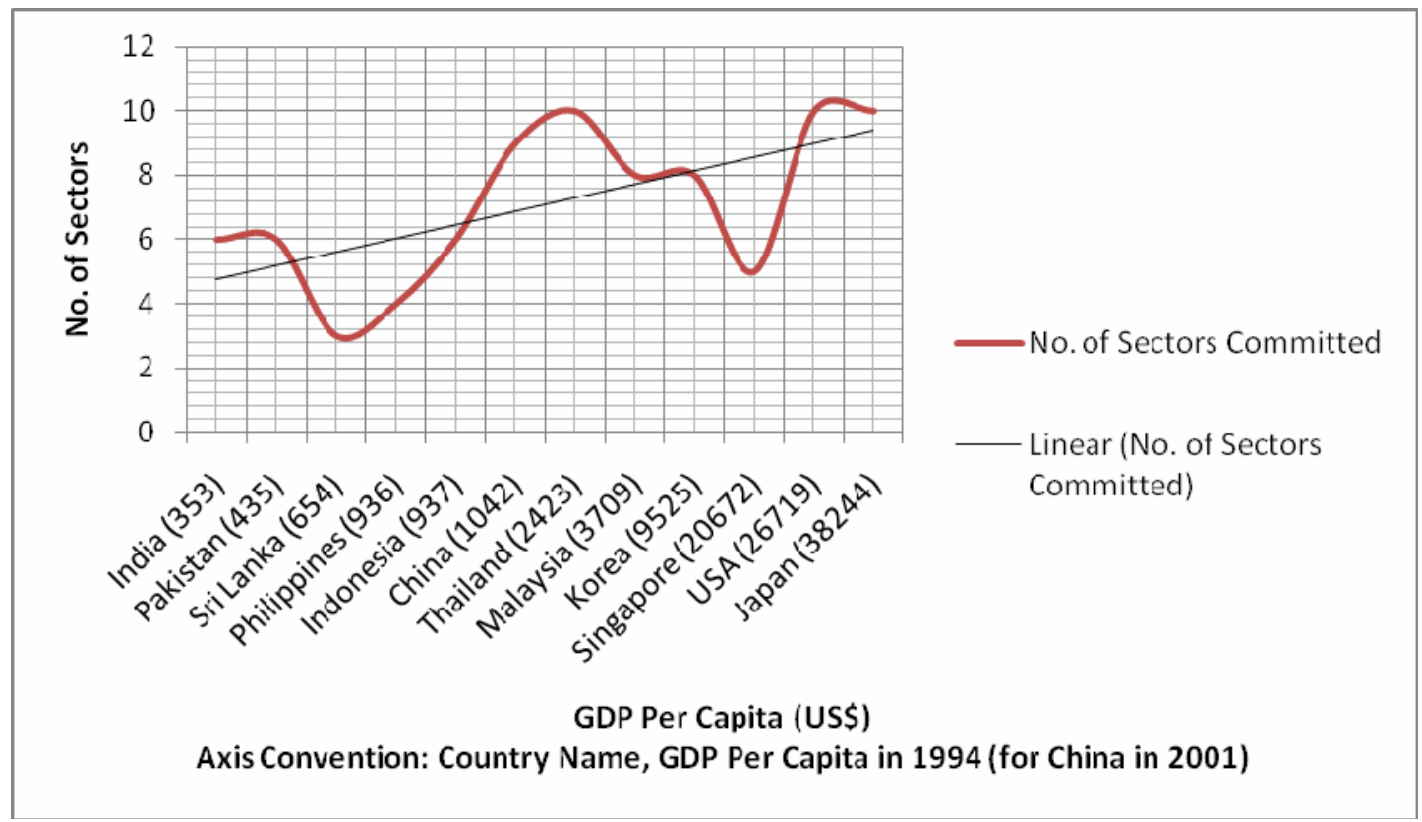

Source: Based on country's GATS commitments available at the WTO website (www.wto.org) and GDP per capita data from http://data.worldbank.org/indicator/NY.GDP.MKTP.CD 
Figure 2 Number of Subsectors in which commitments were made under the GATS and GDP per capita

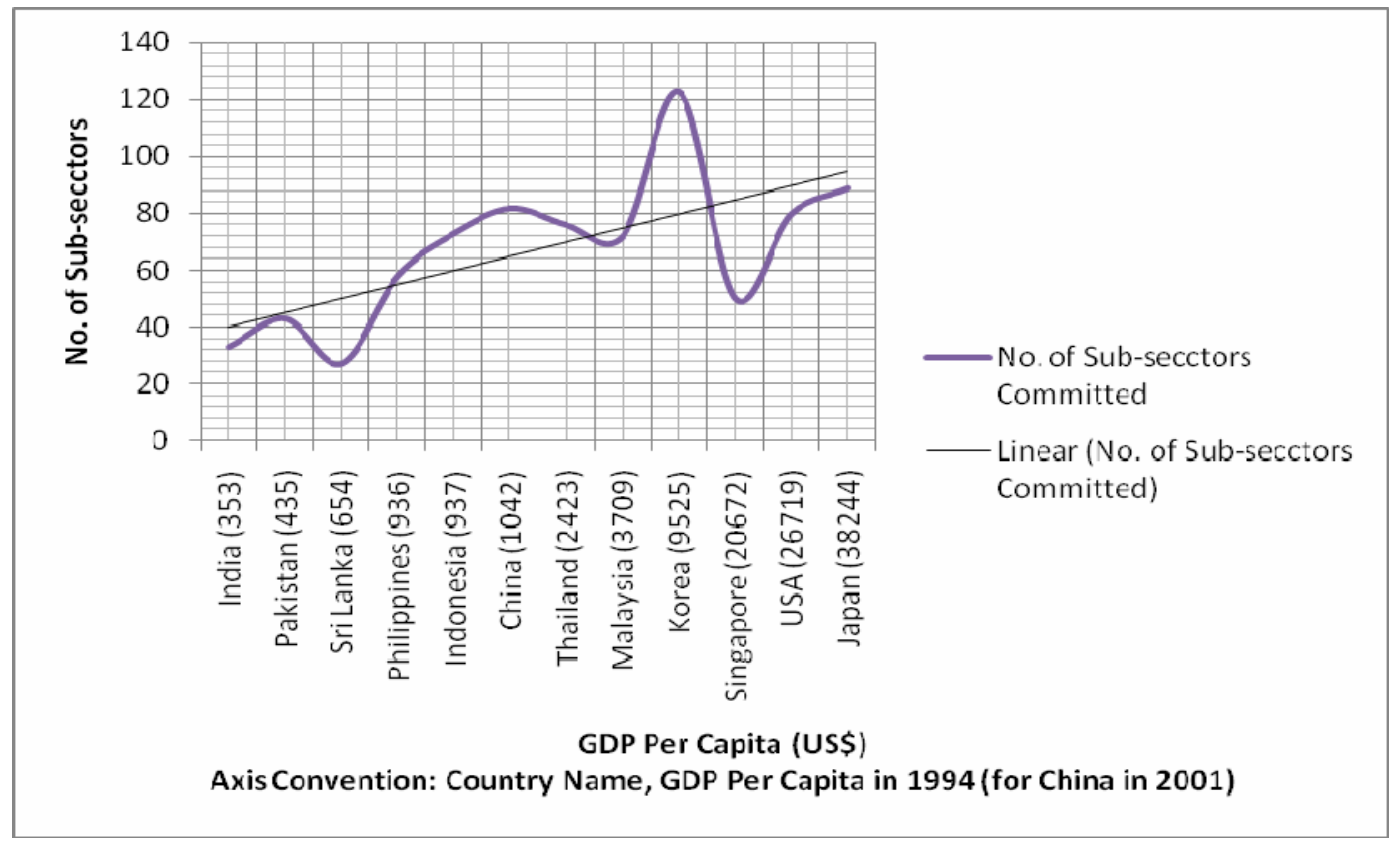

Source: Based on country's GATS commitments available at the WTO website (www.wto.org) and GDP per capita data from http://data.worldbank.org/indicator/NY.GDP.MKTP.CD

Figure 3 Number of Sectors in which commitments were made under selected PTAs and GDP per capita

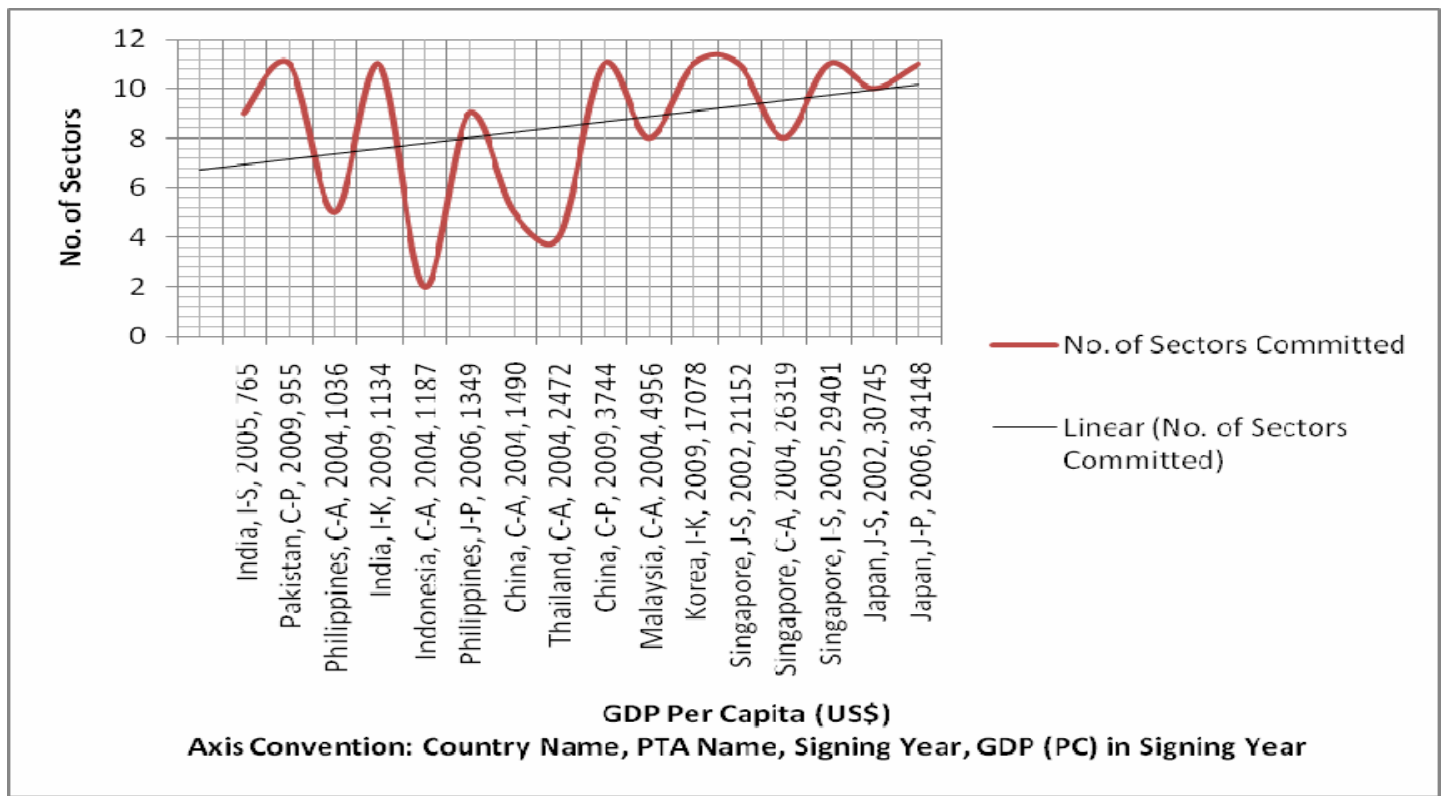

Source: Based on analysis of country's schedules of commitments under the selected PTAs and GDP per capita data from http://data.worldbank.org/indicator/NY.GDP.MKTP.CD 
Figure 4 Number of subsectors in which commitments were made under selected PTAs and GDP per capita

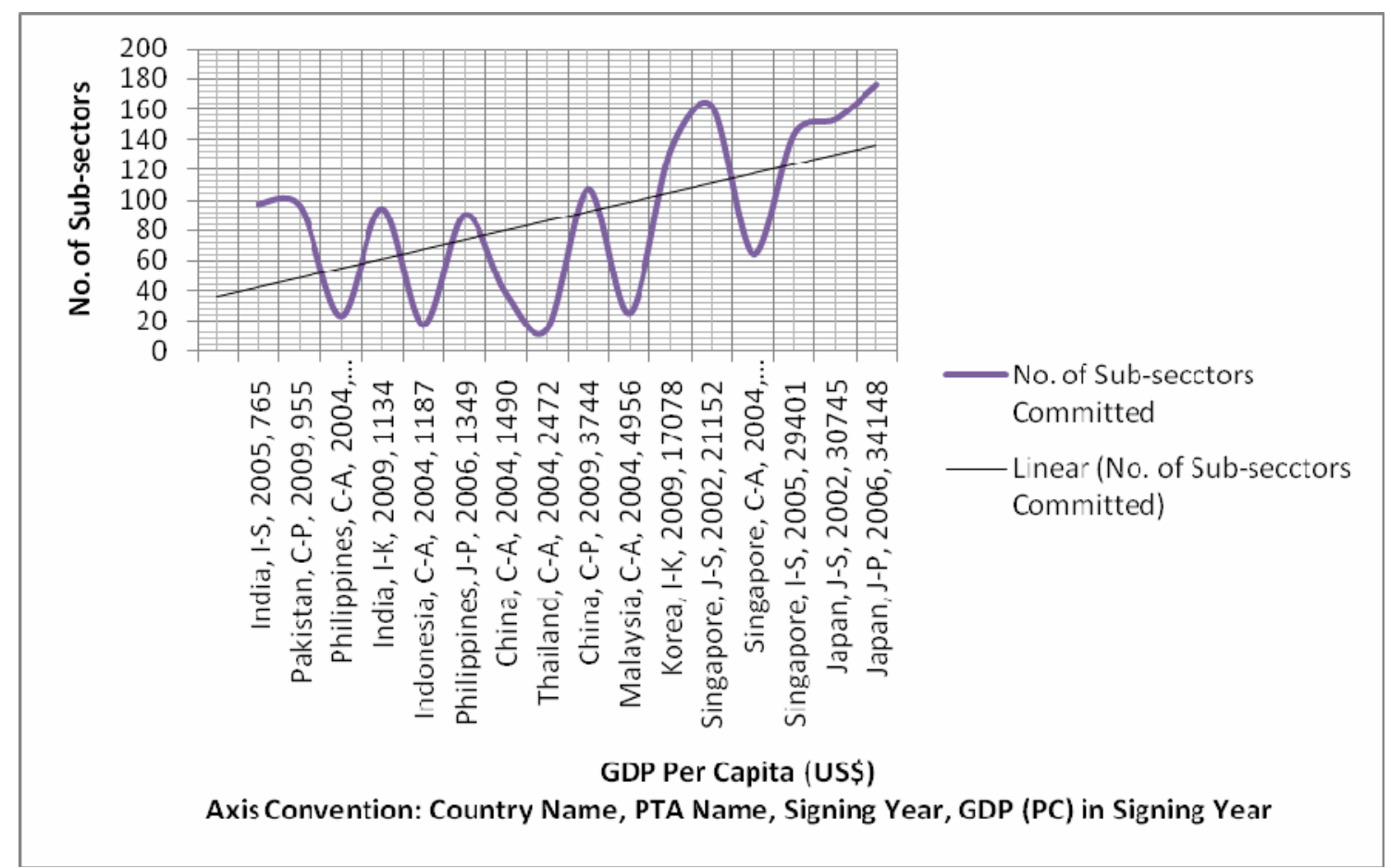

Source: Based on analysis of country's schedules of commitments under the selected PTAs and GDP per capita data from http://data.worldbank.org/indicator/NY.GDP.MKTP.CD

One interesting feature that emerges, however, is that countries have not tended to progressively improve in any significant way on the scope of their commitments by scheduling a much larger number of sectors or subsectors under subsequent PTAs. Thus, while relative to the GATS, the scope tends to improve, relative to earlier PTAs, the scope increased slightly in some cases or is almost the same in later PTAs. This reconfirms the fact that while countries are willing to offer more under bilateral agreements, they still tend to customize the scope and nature of their liberalization commitments to take into account their interests and sensitivities with different trading partners.

\subsection{Modal features of liberalization commitments}

Another dimension for analysing the nature of liberalization undertaken in the PTAs relative to the GATS is in terms of the modal distribution, i.e., whether countries exhibit similar willingness to liberalize certain modes of supply over others in their PTAs, and what kinds of restrictions they tend to maintain under PTAs compared to the GATS. Such an analysis permits one to go beyond the scope of country commitments to understand the depth of these commitments under PTAs relative to the GATS.

Tables 11a to $11 \mathrm{~d}$ summarize the modal distribution of commitments made by the countries concerned in four service sectors, namely, business, construction, communication, and financial services, under 6 of the PTAs discussed in this paper, relative to the modal distribution of the commitments undertaken by these same countries under the GATS. The figures for Modes 1 and 2 represent the percentage of all commitments in these modes which are not subject to any restrictions (scheduled as "None"), the balance 
being either unbound or partial in these modes. In several cases, this balance share mostly comprises unbound commitments in the case of mode 1 especially. The figures for mode 3 represent the share of all commitments which are without restrictions (i.e., scheduled as "None"). While the balance share of commitments can be either partial or unbound, these have been listed as partial commitments as the majority of mode 3 commitments are partial and only a small fraction are unbound, when not subject to restrictions.

Table 11a Status of commitments for Modes 1, 2, and 3 for business services under GATS and PTAs (\%)

\begin{tabular}{|c|c|c|c|c|c|c|c|c|c|}
\hline \multirow{4}{*}{ PTA Name } & \multirow{4}{*}{ Country } & \multicolumn{8}{|c|}{ Business Services } \\
\hline & & \multicolumn{4}{|c|}{ GATS } & \multicolumn{4}{|c|}{ PTA } \\
\hline & & \multirow[b]{2}{*}{ M1 } & \multirow[b]{2}{*}{ M2 } & \multicolumn{2}{|c|}{ M3 } & \multirow[b]{2}{*}{ M1 } & \multirow[b]{2}{*}{ M2 } & \multicolumn{2}{|c|}{ M3 } \\
\hline & & & & $\begin{array}{c}\text { No } \\
\text { Restrict- } \\
\text { ion }\end{array}$ & $\begin{array}{l}\text { Partial } \\
\text { Commit- } \\
\text { ment }\end{array}$ & & & $\begin{array}{c}\text { No } \\
\text { Restriction }\end{array}$ & $\begin{array}{l}\text { Partial } \\
\text { Commit- } \\
\text { ment }\end{array}$ \\
\hline \multirow{2}{*}{$\begin{array}{l}\text { India- } \\
\text { Korea } \\
\text { CEPA }\end{array}$} & India & 0.00 & 0.00 & 0.00 & 100.00 & 91.18 & 100 & 85.29 & 14.71 \\
\hline & Korea & 65.71 & 60.00 & 88.57 & 11.43 & 78.00 & 94.00 & 84.00 & 16.00 \\
\hline \multirow{2}{*}{$\begin{array}{c}\text { India- } \\
\text { Singapore } \\
\text { CECA } \\
\end{array}$} & India & 0.00 & 0.00 & 0.00 & 100.00 & 80 & 100 & 88.57 & 11.43 \\
\hline & Singapore & 95.45 & 100.00 & 90.91 & 9.09 & 79.6 & 100.0 & 87.76 & 12.24 \\
\hline \multirow{2}{*}{$\begin{array}{l}\text { Japan- } \\
\text { Singapore } \\
\text { CECA }\end{array}$} & Japan & 60.71 & 78.57 & 85.71 & 14.30 & 42.56 & 72.34 & 74.46 & 25.54 \\
\hline & Singapore & 95.45 & 100.00 & 90.91 & 9.09 & 69.09 & 90.91 & 85.45 & 14.55 \\
\hline \multirow{2}{*}{$\begin{array}{c}\text { Japan- } \\
\text { Philippines } \\
\text { EPA }\end{array}$} & Japan & 60.71 & 78.57 & 85.71 & 14.30 & 69.05 & 88.10 & 88.10 & 11.90 \\
\hline & $\begin{array}{l}\text { Philippine } \\
\text { s }\end{array}$ & 0.00 & 0.00 & 0.00 & 100.00 & 40.0 & 60.0 & 0.00 & 100.0 \\
\hline \multirow{2}{*}{$\begin{array}{c}\text { China- } \\
\text { Pakistan } \\
\text { FTA }\end{array}$} & China & 95.45 & 95.45 & 13.64 & 86.36 & 67.74 & 74.19 & 19.35 & 80.65 \\
\hline & Pakistan & 0.00 & 50.00 & 80.00 & 20.00 & 69.57 & 82.61 & 43.48 & 56.52 \\
\hline \multirow{6}{*}{$\begin{array}{l}\text { China- } \\
\text { ASEAN } \\
\text { FTA }\end{array}$} & China & 95.45 & 95.45 & 13.64 & 86.36 & 71.43 & 71.43 & 14.30 & 85.71 \\
\hline & Indonesia & 0.00 & 0.00 & 0.00 & 0.00 & 0.00 & 0.00 & 0.00 & 0.00 \\
\hline & Malaysia & 96.55 & 100.00 & 6.90 & 93.10 & 100.0 & 100.0 & 100.00 & 0.00 \\
\hline & $\begin{array}{c}\text { Philippine } \\
\text { S } \\
\end{array}$ & 0.00 & 0.00 & 0.00 & 0.00 & 100.0 & 100.0 & 0.00 & 100.0 \\
\hline & Singapore & 95.45 & 100.00 & 90.91 & 9.09 & 94.12 & 100.0 & 94.12 & 5.88 \\
\hline & Thailand & 4.35 & 100.00 & 0.00 & 100.00 & 100.0 & 100.0 & 25.00 & 75.00 \\
\hline
\end{tabular}

Source: Author's calculations based on country's GATS commitments available at the WTO website (www.wto.org) and text documents of country's PTAs. 
Table $11 \mathrm{~b}$ Status of commitments for Modes 1, 2, and 3 for communication services under GATS and PTAs (\%)

\begin{tabular}{|c|c|c|c|c|c|c|c|c|c|}
\hline \multirow{4}{*}{ PTA Name } & \multirow{4}{*}{ Country } & \multicolumn{8}{|c|}{ Communication Services } \\
\hline & & \multicolumn{4}{|c|}{ GATS } & \multicolumn{4}{|c|}{ PTA } \\
\hline & & \multirow[b]{2}{*}{ M1 } & \multirow[b]{2}{*}{ M2 } & \multicolumn{2}{|c|}{ M3 } & \multirow[b]{2}{*}{ M1 } & \multirow[b]{2}{*}{ M2 } & \multicolumn{2}{|c|}{ M3 } \\
\hline & & & & $\begin{array}{c}\text { No } \\
\text { Restriction }\end{array}$ & $\begin{array}{c}\text { Partial } \\
\text { Commitm } \\
\text { ent }\end{array}$ & & & $\begin{array}{c}\text { No } \\
\text { Restrict } \\
\text { ion }\end{array}$ & $\begin{array}{l}\text { Partial } \\
\text { Commit } \\
\text { ment }\end{array}$ \\
\hline \multirow{2}{*}{$\begin{array}{c}\text { India-Korea } \\
\text { CEPA }\end{array}$} & India & 83.33 & 0.00 & 0.00 & 100.00 & 31.25 & 93.75 & 0.00 & 100.00 \\
\hline & Korea & 100.00 & 100.0 & 100.00 & 0.00 & 52.63 & 100.00 & 52.63 & 47.37 \\
\hline \multirow{2}{*}{$\begin{array}{l}\text { India- } \\
\text { Singapore } \\
\text { CECA } \\
\end{array}$} & India & 83.33 & 0.00 & 0.00 & 100.00 & 12.50 & 87.50 & 0.00 & 100.00 \\
\hline & Singapore & 33.33 & 100.0 & 100.00 & 0.00 & 50.00 & 100.00 & 50.00 & 0.00 \\
\hline \multirow{2}{*}{$\begin{array}{c}\text { Japan- } \\
\text { Singapore } \\
\text { CECA } \\
\end{array}$} & Japan & 93.33 & 100.0 & 100.00 & 0.00 & 85.00 & 100.00 & 55.00 & 45.00 \\
\hline & Singapore & 33.33 & 100.0 & 100.00 & 0.00 & 100.00 & 100.00 & 100.00 & 0.00 \\
\hline \multirow{2}{*}{$\begin{array}{c}\text { Japan- } \\
\text { Philippines } \\
\text { EPA }\end{array}$} & Japan & 93.33 & 100.0 & 100.00 & 0.00 & 85.71 & 100.00 & 28.57 & 71.43 \\
\hline & Philippines & 0.00 & 100.0 & 100.00 & 0.00 & 84.21 & 100.00 & 0.00 & 100.00 \\
\hline \multirow{2}{*}{$\begin{array}{l}\text { China- } \\
\text { Pakistan } \\
\text { FTA }\end{array}$} & China & 72.73 & 100.0 & 0.00 & 100.00 & 23.08 & 69.23 & 23.08 & 76.92 \\
\hline & Pakistan & 45.46 & 81.82 & 63.64 & 16.36 & 80.00 & 60.00 & 80.00 & 20.00 \\
\hline \multirow{6}{*}{$\begin{array}{c}\text { China- } \\
\text { ASEAN FTA }\end{array}$} & China & 72.73 & 100.0 & 0.00 & 100.00 & 0.00 & 0.00 & 0.00 & 0.00 \\
\hline & Indonesia & 0.00 & 0.00 & 0.00 & 100.00 & 0.00 & 0.00 & 0.00 & 0.00 \\
\hline & Malaysia & 40.00 & 100.0 & 80.00 & 20.00 & 100.00 & 100.00 & 0.00 & 100.00 \\
\hline & Philippines & 0.00 & 100.0 & 100.00 & 0.00 & 0.00 & 100.00 & 0.00 & 100.00 \\
\hline & Singapore & 33.33 & 100.0 & 100.00 & 0.00 & 20.00 & 100.00 & 20.00 & 80.00 \\
\hline & Thailand & 40.00 & 100.0 & 20.00 & 80.00 & 0.00 & 0.00 & 0.00 & 0.00 \\
\hline
\end{tabular}

Source: Author's calculations based on country's GATS commitments available at the WTO website (www.wto.org) and text documents of country's PTAs.

Note: Entries in red refer to cases where the sector has not been scheduled by the country concerned under the PTA or under the GATS. In such cases, partial has to be interpreted as no commitment. 
Table 11c Status of commitments for Modes 1, 2, and 3 for construction services under GATS and PTAs (\%)

\begin{tabular}{|c|c|c|c|c|c|c|c|c|c|}
\hline \multirow{4}{*}{ PTA Name } & \multirow{4}{*}{ Country } & \multicolumn{8}{|c|}{ Construction Services } \\
\hline & & \multicolumn{4}{|c|}{ GATS } & \multicolumn{4}{|c|}{ PTA } \\
\hline & & \multirow[b]{2}{*}{ M1 } & \multirow[b]{2}{*}{ M2 } & \multicolumn{2}{|c|}{ M3 } & \multirow[b]{2}{*}{ M1 } & \multirow[b]{2}{*}{ M2 } & \multicolumn{2}{|c|}{ M3 } \\
\hline & & & & $\begin{array}{c}\text { No } \\
\text { Restriction }\end{array}$ & $\begin{array}{c}\text { Partial } \\
\text { Commitme } \\
\text { nt }\end{array}$ & & & $\begin{array}{c}\text { No } \\
\text { Restriction }\end{array}$ & $\begin{array}{c}\text { Partial } \\
\text { Commit } \\
\text { ment }\end{array}$ \\
\hline \multirow{2}{*}{$\begin{array}{l}\text { India- } \\
\text { Korea } \\
\text { CEPA }\end{array}$} & India & 0.00 & 0.00 & 0.00 & 100.00 & 100.0 & 100.0 & 100.0 & 0.00 \\
\hline & Korea & 85.71 & 85.71 & 85.71 & 14.29 & 0.00 & 100.00 & 0.00 & 100.00 \\
\hline \multirow{2}{*}{$\begin{array}{l}\text { India- } \\
\text { Singapore } \\
\text { CECA }\end{array}$} & India & 0.00 & 0.00 & 0.00 & 100.00 & 100.0 & 100.0 & 100.0 & 0.00 \\
\hline & Singapore & 100.0 & 100.0 & 100.0 & 0.00 & 100.0 & 100.0 & 100.0 & 0.00 \\
\hline \multirow{2}{*}{$\begin{array}{c}\text { Japan- } \\
\text { Singapore } \\
\text { CECA }\end{array}$} & Japan & 100.00 & 100.00 & 100.00 & 0.00 & 75.00 & 93.75 & 75.00 & 0.00 \\
\hline & Singapore & 100.0 & 100.0 & 100.0 & 0.00 & 60.00 & 100.00 & 100.00 & 0.00 \\
\hline \multirow{2}{*}{$\begin{array}{c}\text { Japan- } \\
\text { Philippines } \\
\text { EPA } \\
\end{array}$} & Japan & 100.00 & 100.00 & 100.00 & 0.00 & 100.00 & 100.00 & 100.00 & 0.00 \\
\hline & Philippines & 0.00 & 0.00 & 0.00 & 0.00 & 0.00 & 0.00 & 0.00 & 0.00 \\
\hline \multirow{2}{*}{$\begin{array}{c}\text { China- } \\
\text { Pakistan } \\
\text { FTA } \\
\end{array}$} & China & 100.0 & 100.00 & 0.00 & 100.00 & 40.00 & 80.00 & 60.00 & 40.00 \\
\hline & Pakistan & 0.00 & 0.00 & 0.00 & 100.00 & 66.67 & 0.00 & 100.00 & 0.00 \\
\hline \multirow{6}{*}{$\begin{array}{c}\text { China- } \\
\text { ASEAN } \\
\text { FTA }\end{array}$} & China & 100.00 & 100.00 & 0.00 & 100.00 & 100.00 & 100.00 & 0.00 & 100.00 \\
\hline & Indonesia & 0.00 & 0.00 & 0.00 & 0.00 & 0.00 & 100.00 & 0.00 & 100.00 \\
\hline & Malaysia & 0.00 & 100.00 & 0.00 & 100.00 & 0.00 & 100.00 & 0.00 & 100.00 \\
\hline & Philippines & 0.00 & 0.00 & 0.00 & 0.00 & 100.00 & 100.00 & 0.00 & 100.00 \\
\hline & Singapore & 100.0 & 100.0 & 100.0 & 0.00 & 0.00 & 0.00 & 0.00 & 0.00 \\
\hline & Thailand & 0.00 & 100.00 & 0.00 & 100.00 & 0.00 & 0.00 & 0.00 & 0.00 \\
\hline
\end{tabular}

Source: Author's calculations based on country's GATS commitments available at the WTO website (www.wto.org) and text documents of country's PTAs.

Note: Entries in red refer to cases where the sector has not been scheduled by the country concerned under the PTA or under the GATS. In such cases, partial has to be interpreted as no commitment. 
Table 11d Status of commitments for Modes 1, 2, and 3 for financial services under GATS and PTAs (\%)

\begin{tabular}{|c|c|c|c|c|c|c|c|c|c|}
\hline \multirow{4}{*}{ PTA Name } & \multirow{4}{*}{ Country } & \multicolumn{8}{|c|}{ Financial Services } \\
\hline & & \multicolumn{4}{|c|}{ GATS } & \multicolumn{4}{|c|}{ PTA } \\
\hline & & \multirow[b]{2}{*}{ M1 } & \multirow[b]{2}{*}{ M2 } & \multicolumn{2}{|c|}{ M3 } & \multirow[b]{2}{*}{ M1 } & \multirow[b]{2}{*}{ M2 } & \multicolumn{2}{|c|}{ M3 } \\
\hline & & & & $\begin{array}{c}\text { No } \\
\text { Restric- } \\
\text { tion }\end{array}$ & $\begin{array}{c}\text { Partial } \\
\text { Commi } \\
\text { tment }\end{array}$ & & & $\begin{array}{c}\text { No } \\
\text { Restriction }\end{array}$ & $\begin{array}{c}\text { Partial } \\
\text { Commitme } \\
\text { nt }\end{array}$ \\
\hline \multirow{2}{*}{$\begin{array}{l}\text { India- } \\
\text { Korea } \\
\text { CEPA }\end{array}$} & India & 13.33 & 6.67 & 16.67 & 73.33 & 26.32 & 26.32 & 42.11 & 57.89 \\
\hline & Korea & 4.55 & 0.00 & 13.63 & 86.37 & 4.17 & 4.17 & 4.17 & 95.83 \\
\hline \multirow{2}{*}{$\begin{array}{c}\text { India- } \\
\text { Singapore } \\
\text { CECA } \\
\end{array}$} & India & 13.33 & 6.67 & 16.67 & 73.33 & 16.67 & 16.67 & 33.33 & 66.67 \\
\hline & Singapore & 70.59 & 82.35 & 35.29 & 64.71 & 29.41 & 94.12 & 11.76 & 88.24 \\
\hline \multirow{2}{*}{$\begin{array}{c}\text { Japan- } \\
\text { Singapore } \\
\text { CECA }\end{array}$} & Japan & 0.00 & 0.00 & 0.00 & 100.00 & 0.00 & 0.00 & 0.00 & 100.00 \\
\hline & Singapore & 70.59 & 82.35 & 35.29 & 64.71 & 100.00 & 100.00 & 0.00 & 100.00 \\
\hline \multirow{2}{*}{$\begin{array}{c}\text { Japan- } \\
\text { Philippines } \\
\text { EPA } \\
\end{array}$} & Japan & 0.00 & 0.00 & 0.00 & 100.00 & 100.00 & 100.00 & 100.00 & 0.00 \\
\hline & Philippines & 11.43 & 82.86 & 2.86 & 97.14 & 0.00 & 0.00 & 0.00 & 100.00 \\
\hline \multirow{2}{*}{$\begin{array}{c}\text { China- } \\
\text { Pakistan } \\
\text { FTA } \\
\end{array}$} & China & 92.31 & 100.00 & 15.38 & 84.62 & 5.26 & 89.47 & 15.79 & 84.21 \\
\hline & Pakistan & 18.75 & 12.50 & 37.50 & 18.75 & 18.75 & 12.50 & 37.50 & 62.50 \\
\hline \multirow{6}{*}{$\begin{array}{c}\text { China- } \\
\text { ASEAN } \\
\text { FTA }\end{array}$} & China & 92.31 & 100.00 & 15.38 & 84.62 & 0.00 & 0.00 & 0.00 & 0.00 \\
\hline & Indonesia & 52.63 & 15.79 & 5.26 & 94.74 & 0.00 & 0.00 & 0.00 & 0.00 \\
\hline & Malaysia & 30.43 & 43.48 & 4.35 & 95.65 & 50.00 & 50.00 & 0.00 & 100.00 \\
\hline & Philippines & 11.43 & 82.86 & 2.86 & 97.14 & 0.00 & 0.00 & 0.00 & 0.00 \\
\hline & Singapore & 70.59 & 82.35 & 35.29 & 64.71 & 29.42 & 94.12 & 35.29 & 64.71 \\
\hline & Thailand & 86.6 & 100.00 & 6.67 & 93.33 & 0.00 & 0.00 & 0.00 & 0.00 \\
\hline
\end{tabular}

Source: Author's calculations based on country's GATS commitments available at the WTO website (www.wto.org) and text documents of country's PTAs.

Note: Entries in red refer to cases where the sector has not been scheduled by the country concerned under the PTA or under the GATS. In such cases, partial has to be interpreted as no commitment.

The preceding tables which summarize the mode-wise nature of commitments made by countries in the selected services highlight several interesting facts. The first is that contrary to expectations, countries have not necessarily improved upon their modal commitments in terms of increasing the share of commitments which are unrestricted. In several cases, the share of mode 1, 2, and 3 commitments which are unrestricted has actually decreased under the PTAs relative to the GATS. This is particularly so under the China-ASEAN PTA, which not only exhibits reduced scope of commitments (with sectors scheduled under the GATS not scheduled under the PTA) but also GATS-minus commitments. Even developed countries such as Japan and Singapore have made more restrictive mode 1 and 2 commitments in some of 
the selected services relative to their commitments in the GATS. This GATS-minus nature of commitments is most evident in the communication services sector. To the extent that there is improvement, this is most visible for mode 3 where countries have made a larger share of their commitments in this mode unrestricted than under the GATS.

The second feature of the mode-wise commitments is that among the countries in this sample, India tends to show the greatest improvement in the depth of its commitments, with a significant increase in the share of unrestricted commitments across modes 1,2 , and 3 for all the selected services except communication services. The improvement is greatest for business services and for modes 1 and 2 . In comparison, the other developing countries in the sample do not show such an improvement; some even show a significant decline in the share of unrestricted commitments. Improvements in developed country commitments are found mainly in financial services.

A third noteworthy feature is that although the modal nature of commitments for a given country tends to be similar across different services, at times it does vary. For instance, Japan has scheduled partial mode 3 commitments in financial services under the Japan-Singapore PTA while under JPEPA, all its mode 3 commitments are unrestricted. Hence, there appears to be some customization of the commitments in line with the strengths of the partner country and associated sectoral sensitivities, in the extent of liberalization undertaken.

Thus, while the range of services under negotiation may be larger under the PTAs, the extent of liberalization is not necessarily greater. In many cases, the commitments are more restrictive than in the GATS. Business services generally see greater improvement than other services, both in scope (as discussed earlier) and in depth of commitments.

The following tables highlight the modal distribution of commitments by some of the countries in this sample to illustrate that for a given country, the extent of liberalization relative to the GATS varies across services and also across its PTAs, and further that there is no consistent pattern that emerges across different countries in terms of their willingness to deepen their modal commitments. Three categories of countries emerge: the first consisting of countries such as India and the Philippines which have made more liberal commitments; the second consisting of countries such as Japan, Singapore, and Korea which have exhibited more as well as less liberalization; and the third category consisting of countries such as China which have tended to go below their GATS commitments. 
Table 12a Status of commitments for Modes 1, 2, and 3 made by India under GATS and the IndiaSingapore CECA (\%)

\begin{tabular}{|c|c|c|c|c|c|c|c|c|c|}
\hline \multirow[b]{3}{*}{ Country } & \multirow[b]{3}{*}{ Service Sector } & \multicolumn{4}{|c|}{ GATS } & \multicolumn{4}{|c|}{ India-Singapore } \\
\hline & & \multirow[b]{2}{*}{ M1 } & \multirow[b]{2}{*}{ M2 } & \multicolumn{2}{|c|}{ M3 } & \multirow[b]{2}{*}{ M1 } & \multirow[b]{2}{*}{ M2 } & \multicolumn{2}{|c|}{ M3 } \\
\hline & & & & $\begin{array}{c}\text { No } \\
\text { Restrict } \\
\text { ion }\end{array}$ & $\begin{array}{c}\text { Partial } \\
\text { Commit } \\
\text { ment }\end{array}$ & & & $\begin{array}{c}\text { No } \\
\text { Restrict } \\
\text { ion }\end{array}$ & $\begin{array}{c}\text { Partial } \\
\text { Commitment }\end{array}$ \\
\hline \multirow{11}{*}{ India } & Business Services & 0.00 & 0.00 & 0.00 & 100.00 & 80.00 & 100.00 & 88.57 & 11.43 \\
\hline & $\begin{array}{l}\text { Communication } \\
\text { Services }\end{array}$ & 83.33 & 0.00 & 0.00 & 100.00 & 12.50 & 87.50 & 0.00 & 100.00 \\
\hline & $\begin{array}{l}\text { Distribution } \\
\text { Services }\end{array}$ & & & & & 100.00 & 100.00 & 100.00 & 0.00 \\
\hline & $\begin{array}{l}\text { Construction } \\
\text { Services }\end{array}$ & 0.00 & 0.00 & 0.00 & 100.00 & 100.00 & 100.00 & 100.00 & 0.00 \\
\hline & $\begin{array}{l}\text { Transport } \\
\text { Services }\end{array}$ & & & & & 50.00 & 70.00 & 80.00 & 20.00 \\
\hline & $\begin{array}{l}\text { Financial } \\
\text { Services } \\
\end{array}$ & 13.33 & 6.67 & 26.67 & 73.33 & 16.67 & 83.33 & 33.33 & 66.67 \\
\hline & Tourism Services & 0.00 & 0.00 & 0.00 & 100.00 & 100.00 & 100.00 & 100.00 & 0.00 \\
\hline & $\begin{array}{l}\text { Education } \\
\text { Services }\end{array}$ & & & & & & & & \\
\hline & $\begin{array}{l}\text { Environment } \\
\text { Services }\end{array}$ & & & & & & & & \\
\hline & Health Services & 0.00 & 0.00 & 0.00 & 100.00 & 100.00 & 100.00 & 100.00 & 0.00 \\
\hline & $\begin{array}{l}\text { Recreational } \\
\text { Services }\end{array}$ & & & & & 100.00 & 100.00 & 100.00 & 0.00 \\
\hline
\end{tabular}

Source: Author's calculations based on country's GATS commitments available at the WTO website (www.wto.org) and text documents of country's PTAs.

Table $12 \mathrm{~b}$ Status of commitments for Modes 1, 2, and 3 made by India under GATS and the India-Korea CEPA (\%)

\begin{tabular}{|c|c|c|c|c|c|c|c|c|c|}
\hline \multirow[b]{3}{*}{ Country } & \multirow[b]{3}{*}{ Service Sector } & \multicolumn{4}{|c|}{ GATS } & \multicolumn{4}{|c|}{ India-Korea } \\
\hline & & \multirow[b]{2}{*}{ M1 } & \multirow[b]{2}{*}{ M2 } & \multicolumn{2}{|c|}{ M3 } & \multirow[b]{2}{*}{ M1 } & \multirow[b]{2}{*}{ M2 } & \multicolumn{2}{|r|}{ M3 } \\
\hline & & & & $\begin{array}{c}\text { No } \\
\text { Restrict } \\
\text { ion }\end{array}$ & $\begin{array}{l}\text { Partial } \\
\text { Commitm } \\
\text { ent }\end{array}$ & & & $\begin{array}{l}\text { No } \\
\text { Restr } \\
\text { iction }\end{array}$ & $\begin{array}{c}\text { Partial } \\
\text { Commitment }\end{array}$ \\
\hline \multirow[t]{7}{*}{ India } & Business Services & 0.00 & 0.00 & 0.00 & 100.00 & 91.18 & 100.0 & 85.29 & 14.71 \\
\hline & $\begin{array}{l}\text { Communication } \\
\text { Services }\end{array}$ & 83.33 & 0.00 & 0.00 & 100.00 & 31.25 & 93.75 & 0.00 & 100.00 \\
\hline & $\begin{array}{l}\text { Distribution } \\
\text { Services }\end{array}$ & & & & & 100.00 & 100.0 & 100.0 & 0.00 \\
\hline & $\begin{array}{l}\text { Construction } \\
\text { Services }\end{array}$ & 0.00 & 0.00 & 0.00 & 100.00 & 100.00 & 100.0 & 100.0 & 0.00 \\
\hline & $\begin{array}{l}\text { Transport } \\
\text { Services }\end{array}$ & & & & & 45.45 & 100.0 & 81.82 & 18.18 \\
\hline & $\begin{array}{l}\text { Financial } \\
\text { Services }\end{array}$ & 13.33 & 6.67 & 26.67 & 73.33 & 26.32 & 26.32 & 42.11 & 57.89 \\
\hline & Tourism Services & 0.00 & 0.00 & 0.00 & 100.00 & 66.67 & 100.0 & 33.33 & 66.67 \\
\hline
\end{tabular}




\begin{tabular}{|c|c|c|c|c|c|c|c|c|}
\hline $\begin{array}{l}\text { Education } \\
\text { Services }\end{array}$ & & & & & 100.00 & 100.0 & 100.0 & 0.00 \\
\hline $\begin{array}{l}\text { Environment } \\
\text { Services }\end{array}$ & & & & & 100.00 & 100.0 & 100.0 & 0.00 \\
\hline Health Services & 0.00 & 0.00 & 0.00 & 100.00 & 100.00 & 100.0 & 100.0 & 0.00 \\
\hline $\begin{array}{l}\text { Recreational } \\
\text { Services }\end{array}$ & & & & & 50.00 & 100.0 & 100.0 & 0.00 \\
\hline
\end{tabular}

Source: Author's calculations based on country's GATS commitments available at the WTO website (www.wto.org) and text documents of country's PTAs.

Table 12c Status of commitments for Modes 1, 2, and 3 made by the Philippines under GATS and JPEPA $(\%)$

\begin{tabular}{|c|c|c|c|c|c|c|c|c|c|}
\hline \multirow[b]{3}{*}{ Country } & \multirow[b]{3}{*}{ Service Sector } & \multicolumn{4}{|c|}{ GATS } & \multicolumn{4}{|c|}{ JPEPA } \\
\hline & & \multirow[b]{2}{*}{ M1 } & \multirow[b]{2}{*}{ M2 } & \multicolumn{2}{|c|}{ M3 } & \multirow[b]{2}{*}{ M1 } & \multirow[b]{2}{*}{ M2 } & \multicolumn{2}{|c|}{ M3 } \\
\hline & & & & $\begin{array}{c}\text { No } \\
\text { Restricti } \\
\text { on }\end{array}$ & $\begin{array}{l}\text { Partial } \\
\text { Commitm } \\
\text { ent }\end{array}$ & & & $\begin{array}{c}\text { No } \\
\text { Restricti } \\
\text { on }\end{array}$ & $\begin{array}{c}\text { Partial } \\
\text { Commit } \\
\text { ment }\end{array}$ \\
\hline \multirow{11}{*}{ Philippines } & $\begin{array}{l}\text { Business } \\
\text { Services } \\
\end{array}$ & & & & & 40.00 & 60.00 & 0.00 & 100.00 \\
\hline & $\begin{array}{l}\text { Communicati } \\
\text { on Services }\end{array}$ & 0.00 & 100.00 & 100.00 & 0.00 & 84.21 & 100.00 & 0.00 & 100.00 \\
\hline & $\begin{array}{l}\text { Distribution } \\
\text { Services }\end{array}$ & & & & & 100.00 & 100.00 & 0.00 & 100.00 \\
\hline & $\begin{array}{l}\text { Construction } \\
\text { Services }\end{array}$ & & & & & 0.00 & 0.00 & 100.00 & 0.00 \\
\hline & $\begin{array}{l}\text { Transport } \\
\text { Services }\end{array}$ & 35.71 & 92.86 & 78.57 & 21.43 & 100.00 & 94.44 & 0.00 & 100.00 \\
\hline & $\begin{array}{l}\text { Financial } \\
\text { Services }\end{array}$ & 11.43 & 82.86 & 2.86 & 97.14 & & & 0.00 & 100.00 \\
\hline & $\begin{array}{l}\text { Tourism } \\
\text { Services }\end{array}$ & 25.00 & 100.00 & 0.00 & 100.00 & 60.00 & 100.00 & 0.00 & 100.00 \\
\hline & $\begin{array}{l}\text { Education } \\
\text { Services }\end{array}$ & & & & & 66.67 & 100.00 & 0.00 & 100.00 \\
\hline & $\begin{array}{l}\text { Environment } \\
\text { Services }\end{array}$ & & & & & 100.00 & 100.00 & 0.00 & 100.00 \\
\hline & $\begin{array}{l}\text { Health } \\
\text { Services }\end{array}$ & & & & & 100.00 & 100.00 & 0.00 & 100.00 \\
\hline & $\begin{array}{l}\text { Recreational } \\
\text { Services }\end{array}$ & & & & & 100.00 & 100.00 & 0.00 & 100.00 \\
\hline
\end{tabular}

Source: Author's calculations based on country's GATS commitment available at the WTO website (www.wto.org) and text documents of country's PTAs 
Table 12d Status of commitments for Modes 1, 2, and 3 made by the Philippines under GATS and China-ASEAN agreement (\%)

\begin{tabular}{|c|c|c|c|c|c|c|c|c|c|}
\hline \multirow[b]{3}{*}{ Country } & \multirow[b]{3}{*}{ Service Sector } & \multicolumn{4}{|c|}{ GATS } & \multicolumn{4}{|c|}{ China-ASEAN } \\
\hline & & \multirow[b]{2}{*}{ M1 } & \multirow[b]{2}{*}{ M2 } & \multicolumn{2}{|c|}{ M3 } & \multirow[b]{2}{*}{ M1 } & \multirow[b]{2}{*}{ M2 } & \multicolumn{2}{|c|}{ M3 } \\
\hline & & & & $\begin{array}{c}\text { No } \\
\text { Restriction }\end{array}$ & $\begin{array}{c}\text { Partial } \\
\text { Commitm } \\
\text { ent }\end{array}$ & & & $\begin{array}{c}\text { No } \\
\text { Restricti } \\
\text { on }\end{array}$ & $\begin{array}{c}\text { Partial } \\
\text { Commit } \\
\text { ment }\end{array}$ \\
\hline \multirow{11}{*}{ Philippines } & $\begin{array}{l}\text { Business } \\
\text { Services }\end{array}$ & & & & & 100.00 & 100.0 & 0.00 & 100.00 \\
\hline & $\begin{array}{l}\text { Communicati } \\
\text { on Services }\end{array}$ & 0.00 & 100.00 & 100.00 & 0.00 & 75.00 & $\begin{array}{r}100.0 \\
0\end{array}$ & 0.00 & 100.00 \\
\hline & $\begin{array}{l}\text { Distribution } \\
\text { Services }\end{array}$ & & & & & & & & \\
\hline & $\begin{array}{l}\text { Construction } \\
\text { Services }\end{array}$ & & & & & 100.00 & 100.0 & 0.00 & 100.00 \\
\hline & $\begin{array}{l}\text { Transport } \\
\text { Services }\end{array}$ & 35.71 & 92.86 & 78.57 & 21.43 & 75.00 & 100.0 & 0.00 & 100.00 \\
\hline & $\begin{array}{l}\text { Financial } \\
\text { Services }\end{array}$ & 11.43 & 82.86 & 2.86 & 97.14 & & & & \\
\hline & $\begin{array}{l}\text { Tourism } \\
\text { Services }\end{array}$ & 25.00 & 100.00 & 0.00 & 100.00 & & & & \\
\hline & $\begin{array}{l}\text { Education } \\
\text { Services }\end{array}$ & & & & & & & & \\
\hline & $\begin{array}{l}\text { Environment } \\
\text { Services }\end{array}$ & & & & & 100.00 & 100.0 & 0.00 & 100.00 \\
\hline & $\begin{array}{l}\text { Health } \\
\text { Services }\end{array}$ & & & & & & & & \\
\hline & $\begin{array}{l}\text { Recreational } \\
\text { Services }\end{array}$ & & & & & 100.00 & $\begin{array}{r}100.0 \\
0\end{array}$ & 0.00 & 100.00 \\
\hline
\end{tabular}

Source: Author's calculations based on country's GATS commitments available at the WTO website (www.wto.org) and text documents of country's PTAs.

It is evident from the nature of India's commitments under the GATS and under the India-Singapore and the India-Korea PTAs that across all 11 service sectors, India has significantly increased the share of all commitments that are unrestricted, across modes 1,2, and 3. Several services which were not scheduled under the GATS, such as education, transport, and environmental services, have been committed under these PTAs, with $100 \%$ unrestricted commitments across the three modes. Likewise, in the case of the Philippines, the number of services scheduled under its PTAs has increased as has the share of unrestricted commitments, except for financial services. Overall, there is a GATS + nature to the PTA commitments made by both these countries.

In contrast, the picture is quite different for Korea, Singapore, and Japan whose commitments show a mix of improvement and backtracking on the GATS, as shown in Tables 13a to 13e below. 
Table 13a Status of commitments for Modes 1, 2, and 3 made by Korea under GATS and the IndiaKorea PTA (\%)

\begin{tabular}{|c|c|c|c|c|c|c|c|c|c|}
\hline \multirow[b]{3}{*}{ Country } & \multirow[b]{3}{*}{ Service Sector } & \multicolumn{4}{|c|}{ GATS } & \multicolumn{4}{|c|}{ India-Korea } \\
\hline & & \multirow[b]{2}{*}{ M1 } & \multirow[b]{2}{*}{ M2 } & \multicolumn{2}{|c|}{ M3 } & \multirow[b]{2}{*}{ M1 } & \multirow[b]{2}{*}{ M2 } & \multicolumn{2}{|r|}{ M3 } \\
\hline & & & & $\begin{array}{c}\text { No } \\
\text { Restriction }\end{array}$ & $\begin{array}{c}\text { Partial } \\
\text { Commitm } \\
\text { ent }\end{array}$ & & & $\begin{array}{c}\text { No } \\
\text { Restr } \\
\text { ictio } \\
\text { n }\end{array}$ & $\begin{array}{c}\text { Partial } \\
\text { Commitment }\end{array}$ \\
\hline \multirow{11}{*}{ Korea } & Business Services & 65.71 & 60.00 & 88.57 & 11.43 & 78.00 & 94.00 & 84.00 & 16.00 \\
\hline & $\begin{array}{l}\text { Communication } \\
\text { Services }\end{array}$ & 100.00 & 100.00 & 100.00 & 0.00 & 52.63 & 100.0 & 52.63 & 47.37 \\
\hline & $\begin{array}{l}\text { Distribution } \\
\text { Services }\end{array}$ & 14.29 & 14.29 & 0.00 & 100.00 & 25.00 & 100.0 & 50.00 & 50.00 \\
\hline & $\begin{array}{l}\text { Construction } \\
\text { Services }\end{array}$ & 85.71 & 85.71 & 85.71 & 14.29 & 0.00 & 100.0 & 0.00 & 100.00 \\
\hline & $\begin{array}{l}\text { Transport } \\
\text { Services }\end{array}$ & 43.75 & 100.00 & 43.75 & 56.25 & 45.45 & 90.90 & 59.09 & 40.91 \\
\hline & $\begin{array}{l}\text { Financial } \\
\text { Services }\end{array}$ & 4.55 & 0.00 & 13.64 & 86.36 & 4.17 & 4.17 & 4.17 & 95.83 \\
\hline & Tourism Services & 50.00 & 100.00 & 100.00 & 0.00 & 100.0 & 100.0 & 100.0 & 0.00 \\
\hline & $\begin{array}{l}\text { Education } \\
\text { Services }\end{array}$ & & & & & 0.00 & 100.0 & 0.00 & 100.00 \\
\hline & $\begin{array}{l}\text { Environment } \\
\text { Services }\end{array}$ & 66.67 & 100.00 & 66.67 & 0.00 & 50.00 & 100.0 & 100.0 & 0.00 \\
\hline & Health Services & & & & & & & & \\
\hline & $\begin{array}{l}\text { Recreational } \\
\text { Services }\end{array}$ & & & & & 0.00 & 100.0 & 100.0 & 0.00 \\
\hline
\end{tabular}

Source: Author's calculations based on country's GATS commitments available at the WTO website (www.wto.org) and text documents of country's PTAs.

Table 13b Status of commitments for Modes 1, 2, and 3 by Singapore under GATS and the JapanSingapore PTA (\%)

\begin{tabular}{|c|c|c|c|c|c|c|c|c|c|}
\hline \multirow[b]{3}{*}{ Country } & \multirow[b]{3}{*}{ Service Sector } & \multicolumn{4}{|c|}{ GATS } & \multicolumn{4}{|c|}{ Japan-Singapore } \\
\hline & & \multirow[b]{2}{*}{ M1 } & \multirow[b]{2}{*}{ M2 } & \multicolumn{2}{|c|}{ M3 } & \multirow[b]{2}{*}{ M1 } & \multirow[b]{2}{*}{ M2 } & \multicolumn{2}{|c|}{ M3 } \\
\hline & & & & $\begin{array}{c}\text { No } \\
\text { Restrict } \\
\text { ion }\end{array}$ & $\begin{array}{c}\text { Partial } \\
\text { Commit } \\
\text { ment }\end{array}$ & & & $\begin{array}{c}\text { No } \\
\text { Restricti } \\
\text { on }\end{array}$ & $\begin{array}{l}\text { Partial } \\
\text { Comm } \\
\text { itment }\end{array}$ \\
\hline \multirow[t]{7}{*}{ Singapore } & Business Services & 95.45 & 100.00 & 90.91 & 9.09 & 69.09 & 90.91 & 85.45 & 14.55 \\
\hline & $\begin{array}{l}\text { Communication } \\
\text { Services }\end{array}$ & 33.33 & 100.0 & 100.00 & 0.00 & 100.0 & 100.0 & 100.00 & 0.00 \\
\hline & $\begin{array}{l}\text { Distribution } \\
\text { Services }\end{array}$ & & & & & 100.0 & 100.0 & 100.00 & 0.00 \\
\hline & $\begin{array}{l}\begin{array}{l}\text { Construction } \\
\text { Services }\end{array} \\
\end{array}$ & 100.0 & 100.0 & 100.0 & 0.00 & 60.00 & 100.0 & 100.00 & 0.00 \\
\hline & $\begin{array}{l}\text { Transport } \\
\text { Services }\end{array}$ & 100.00 & 100.00 & 100.00 & 0.00 & 100.0 & 100.0 & 40.00 & 60.00 \\
\hline & $\begin{array}{l}\text { Financial } \\
\text { Services }\end{array}$ & 70.59 & 82.35 & 35.29 & 64.71 & 100.0 & 100.0 & 0.00 & 100.00 \\
\hline & Tourism Services & 100.00 & 100.00 & 100.00 & 0.00 & 70.59 & 88.24 & 56.00 & 44.0 \\
\hline
\end{tabular}




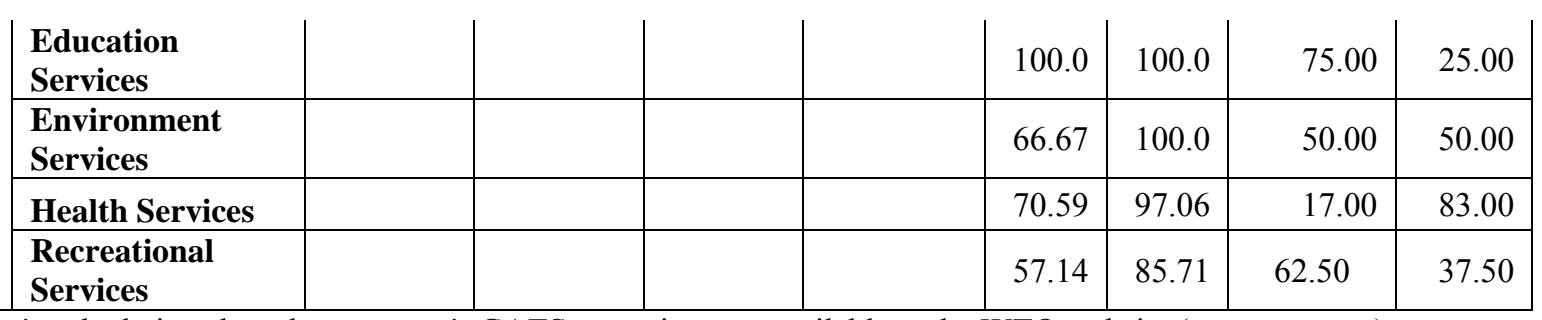

Source: Author's calculations based on country's GATS commitments available at the WTO website (www.wto.org) and text documents of country's PTAs.

Table 13c Status of commitments for Modes 1, 2, and 3 by Singapore under the India-Singapore and China-ASEAN PTAs (\%)

\begin{tabular}{|c|c|c|c|c|c|c|c|c|c|}
\hline \multirow[b]{3}{*}{ v } & \multirow[b]{3}{*}{ Service Sector } & \multicolumn{4}{|c|}{ India-Singapore } & \multicolumn{4}{|c|}{ China-ASEAN } \\
\hline & & \multirow[b]{2}{*}{ M1 } & \multirow[b]{2}{*}{ M2 } & \multicolumn{2}{|c|}{ M3 } & \multirow[b]{2}{*}{ M1 } & \multirow[b]{2}{*}{ M2 } & \multicolumn{2}{|c|}{ M3 } \\
\hline & & & & $\begin{array}{c}\text { No } \\
\text { Restric } \\
\text { tion }\end{array}$ & $\begin{array}{c}\text { Partial } \\
\text { Commit } \\
\text { ment }\end{array}$ & & & $\begin{array}{c}\text { No } \\
\text { Restri } \\
\text { ction }\end{array}$ & $\begin{array}{c}\text { Partial } \\
\text { Commit } \\
\text { ment }\end{array}$ \\
\hline \multirow{11}{*}{ Singapore } & Business Services & 79.59 & 100.00 & 87.76 & 12.24 & 94.12 & 100.00 & 94.12 & 5.88 \\
\hline & $\begin{array}{l}\text { Communication } \\
\text { Services }\end{array}$ & 50.00 & 100.00 & 50.00 & 50.00 & 20.00 & 100.00 & 20.00 & 80.00 \\
\hline & $\begin{array}{l}\text { Distribution } \\
\text { Services }\end{array}$ & 57.14 & 100.00 & 85.71 & 14.29 & 75.00 & 100.00 & 100.00 & 0.00 \\
\hline & $\begin{array}{l}\text { Construction } \\
\text { Services }\end{array}$ & 100.00 & 100.00 & 100.00 & 0.00 & & & & \\
\hline & $\begin{array}{l}\text { Transport } \\
\text { Services } \\
\end{array}$ & 32.26 & 100.00 & 48.39 & 41.61 & 75.00 & 100.00 & 87.50 & 12.50 \\
\hline & Financial Services & 29.41 & 94.12 & 11.76 & 88.24 & 29.42 & 94.12 & 35.29 & 64.71 \\
\hline & Tourism Services & 66.67 & 100.00 & 66.67 & 33.33 & & & & \\
\hline & $\begin{array}{l}\text { Education } \\
\text { Services }\end{array}$ & 100.00 & 100.00 & 100.00 & 0.00 & & & & \\
\hline & $\begin{array}{l}\text { Environment } \\
\text { Services }\end{array}$ & 0.00 & 100.00 & 50.00 & 50.00 & 0.00 & 100.00 & 100.00 & 0.00 \\
\hline & Health Services & 0.00 & 100.00 & 0.00 & 100.0 & 0.00 & 100.00 & 100.00 & 0.00 \\
\hline & $\begin{array}{l}\text { Recreational } \\
\text { Services }\end{array}$ & 57.14 & 100.00 & 71.43 & 28.57 & 75.00 & 100.00 & 100.00 & 0.00 \\
\hline
\end{tabular}

Source: Author's calculations based on country's GATS commitments available at the WTO website (www.wto.org) and text documents of country's PTAs. 
Table 13d Status of commitments for Modes 1, 2, and 3 made by Japan under GATS and JPEPA (\%)

\begin{tabular}{|c|c|c|c|c|c|c|c|c|c|}
\hline \multirow[b]{3}{*}{ Country } & \multirow[b]{3}{*}{ Service Sector } & \multicolumn{4}{|c|}{ GATS } & \multicolumn{4}{|c|}{ JPEPA } \\
\hline & & \multirow[b]{2}{*}{ M1 } & \multirow[b]{2}{*}{ M2 } & \multicolumn{2}{|c|}{ M3 } & \multirow[b]{2}{*}{ M1 } & \multirow[b]{2}{*}{ M2 } & \multicolumn{2}{|c|}{ M3 } \\
\hline & & & & $\begin{array}{c}\text { No } \\
\text { Restrict } \\
\text { ion }\end{array}$ & $\begin{array}{c}\text { Partial } \\
\text { Commit } \\
\text { ment }\end{array}$ & & & $\begin{array}{c}\text { No } \\
\text { Restr } \\
\text { iction }\end{array}$ & $\begin{array}{c}\text { Partial } \\
\text { Commitm } \\
\text { ent }\end{array}$ \\
\hline \multirow{11}{*}{ Japan } & Business Services & 60.71 & 78.57 & 85.70 & 14.30 & 69.05 & 88.10 & 88.10 & 19.90 \\
\hline & $\begin{array}{l}\text { Communication } \\
\text { Services }\end{array}$ & 93.33 & 100.00 & 100.00 & 0.00 & 85.71 & $\begin{array}{r}100.0 \\
0 \\
\end{array}$ & 28.57 & 71.43 \\
\hline & $\begin{array}{l}\text { Distribution } \\
\text { Services }\end{array}$ & 100.00 & 100.00 & 100.00 & 0.00 & 100.0 & 100.0 & 100.0 & 0.00 \\
\hline & $\begin{array}{l}\text { Construction } \\
\text { Services }\end{array}$ & 100.00 & 100.00 & 100.00 & 0.00 & 100.0 & 100.0 & 100.0 & 0.00 \\
\hline & $\begin{array}{l}\text { Transport } \\
\text { Services } \\
\end{array}$ & 69.23 & 76.92 & 69.23 & 30.77 & 54.84 & 96.77 & 67.70 & 33.30 \\
\hline & $\begin{array}{l}\text { Financial } \\
\text { Services }\end{array}$ & 0.00 & 0.00 & 0.00 & 100.00 & 100.0 & 100.0 & 100.0 & 0.00 \\
\hline & Tourism Services & 80.00 & 100.00 & 100.00 & 0.00 & 66.67 & 100.0 & 100.0 & 0.00 \\
\hline & $\begin{array}{l}\text { Education } \\
\text { Services }\end{array}$ & 75.00 & 75.00 & 25.00 & 75.00 & 60.00 & 80.00 & 60.00 & 40.00 \\
\hline & $\begin{array}{l}\text { Environment } \\
\text { Services }\end{array}$ & 100.00 & 100.00 & 75.00 & 25.00 & & & & \\
\hline & Health Services & 100.00 & 100.00 & 0.00 & 100.00 & 100.0 & 100.0 & 0.00 & 100.00 \\
\hline & $\begin{array}{l}\text { Recreational } \\
\text { Services }\end{array}$ & 75.00 & 100.0 & 100.0 & $0.00 \%$ & 85.71 & 100.0 & $\begin{array}{r}100.0 \\
0 \\
\end{array}$ & 0.00 \\
\hline
\end{tabular}

Source: Author's calculations based on country's GATS commitments available at the WTO website (www.wto.org) and text documents of country's PTAs.

Table 13e Status of commitments for Modes 1, 2, and 3 made by Japan under GATS and Japan-Singapore agreement $(\%)$

\begin{tabular}{|c|c|c|c|c|c|c|c|c|c|}
\hline \multirow[b]{3}{*}{ Country } & \multirow[b]{3}{*}{ Service Sector } & \multicolumn{4}{|c|}{ GATS } & \multicolumn{4}{|c|}{ Japan-Singapore } \\
\hline & & \multirow[b]{2}{*}{ M1 } & \multirow[b]{2}{*}{ M2 } & \multicolumn{2}{|c|}{ M3 } & \multirow[b]{2}{*}{ M1 } & \multirow[b]{2}{*}{ M2 } & \multicolumn{2}{|c|}{ M3 } \\
\hline & & & & $\begin{array}{c}\text { No } \\
\text { Restricti } \\
\text { on }\end{array}$ & $\begin{array}{c}\text { Partial } \\
\text { Commit } \\
\text { ment }\end{array}$ & & & $\begin{array}{c}\text { No } \\
\text { Restri } \\
\text { ction }\end{array}$ & $\begin{array}{c}\text { Partial } \\
\text { Commit } \\
\text { ment }\end{array}$ \\
\hline \multirow[t]{8}{*}{ Japan } & Business Services & 60.71 & 78.57 & 85.70 & 14.30 & 42.56 & 72.34 & 74.46 & 25.54 \\
\hline & $\begin{array}{l}\text { Communication } \\
\text { Services }\end{array}$ & 93.33 & 100.00 & 100.00 & 0.00 & 85.00 & 100.0 & 55.00 & 45.00 \\
\hline & $\begin{array}{l}\text { Distribution } \\
\text { Services }\end{array}$ & 100.00 & 100.00 & 100.00 & 0.00 & 100.0 & 100.0 & 50.00 & 50.00 \\
\hline & $\begin{array}{l}\text { Construction } \\
\text { Services }\end{array}$ & 100.00 & 100.00 & 100.00 & 0.00 & 75.00 & 93.75 & 75.00 & 25.00 \\
\hline & $\begin{array}{l}\text { Transport } \\
\text { Services } \\
\end{array}$ & 69.23 & 76.92 & 69.23 & 30.77 & 30.31 & 93.94 & 51.52 & 48.48 \\
\hline & Financial Services & 0.00 & 0.00 & 0.00 & 100.00 & 0.00 & 0.00 & 0.00 & 100.00 \\
\hline & Tourism Services & 80.00 & 100.00 & 100.00 & 0.00 & 50.00 & 100.0 & 100.00 & 0.00 \\
\hline & $\begin{array}{l}\text { Education } \\
\text { Services }\end{array}$ & 75.00 & 75.00 & 25.00 & 75.00 & 57.14 & 71.43 & 42.86 & 57.14 \\
\hline
\end{tabular}




\begin{tabular}{|l|r|r|r|r|r|r|r|r|}
$\begin{array}{l}\text { Environment } \\
\text { Services }\end{array}$ & 100.00 & 100.00 & 75.00 & 25.00 & 0.00 & 0.00 & 0.00 & 100.00 \\
\hline Health Services & 100.00 & 100.00 & 0.00 & 100.00 & 50.00 & 100.0 & 0.00 & 100.00 \\
\hline $\begin{array}{l}\text { Recreational } \\
\text { Services }\end{array}$ & 75.00 & 100.00 & 100.00 & 0.00 & 37.50 & 100.0 & 25.00 & 75.00 \\
\hline
\end{tabular}

Source: Author's calculations based on country's GATS commitments available at the WTO website (www.wto.org) and text documents of country's PTAs.

On the other hand, China's commitments in its PTA with ASEAN and with Pakistan fall below those under the GATS for many services. In some sectors which China has scheduled under the GATS it has not made commitments under these PTAs. The share of unrestricted commitments has declined in several services. There is less scope and less depth in its PTA commitments, possibly reflecting the fact that China was compelled to make extensive commitments under the WTO as part of its accession process while similar considerations may be at work under its PTAs.

Table 14a Status of commitments for Modes 1, 2, and 3 made by China under GATS and the ChinaASEAN PTA (\%)

\begin{tabular}{|c|c|c|c|c|c|c|c|c|c|}
\hline \multirow[b]{3}{*}{ Country } & \multirow[b]{3}{*}{ Service Sector } & \multicolumn{4}{|c|}{ GATS } & \multicolumn{4}{|c|}{ China-ASEAN } \\
\hline & & \multirow[b]{2}{*}{ M1 } & \multirow[b]{2}{*}{ M2 } & \multicolumn{2}{|c|}{ M3 } & \multirow[b]{2}{*}{ M1 } & \multirow[b]{2}{*}{ M2 } & \multicolumn{2}{|c|}{ M3 } \\
\hline & & & & $\begin{array}{c}\text { No } \\
\text { Restriction }\end{array}$ & $\begin{array}{c}\text { Partial } \\
\text { Commit } \\
\text { ment }\end{array}$ & & & $\begin{array}{c}\text { No } \\
\text { Restri } \\
\text { ction }\end{array}$ & $\begin{array}{l}\text { Partial } \\
\text { Comm } \\
\text { itment }\end{array}$ \\
\hline \multirow{11}{*}{ China } & Business Services & 95.45 & 95.45 & 13.64 & 86.36 & 71.43 & 71.43 & 14.29 & 85.71 \\
\hline & $\begin{array}{l}\text { Communication } \\
\text { Services }\end{array}$ & 72.73 & 100.00 & 0.00 & 100.00 & & & & \\
\hline & $\begin{array}{l}\text { Distribution } \\
\text { Services }\end{array}$ & 60.00 & 100.00 & 0.00 & 100.00 & & & & \\
\hline & $\begin{array}{l}\text { Construction } \\
\text { Services }\end{array}$ & 100.0 & 100.00 & 0.00 & 100.00 & 100.0 & 100.0 & $0.00 \%$ & 100.00 \\
\hline & $\begin{array}{l}\text { Transport } \\
\text { Services } \\
\end{array}$ & 41.67 & 100.00 & 9.33 & 91.67 & 50.00 & 62.50 & 0.00 & 100.00 \\
\hline & Financial Services & 92.31 & 100.00 & 15.38 & 84.62 & & & & \\
\hline & Tourism Services & 100.0 & 100.00 & 0.00 & 100.00 & & & & \\
\hline & $\begin{array}{l}\text { Education } \\
\text { Services }\end{array}$ & 100.0 & 100.00 & 0.00 & 100.00 & & & & \\
\hline & $\begin{array}{l}\text { Environment } \\
\text { Services }\end{array}$ & 100.0 & 100.00 & 0.00 & 100.00 & 100.0 & 100.0 & 0.00 & 100.00 \\
\hline & Health Services & & & & & & & & \\
\hline & $\begin{array}{l}\text { Recreational } \\
\text { Services }\end{array}$ & & & & & 100.0 & 100.0 & 0.0 & 100.0 \\
\hline
\end{tabular}

Source: Author's calculations based on country's GATS commitments available at the WTO website (www.wto.org) and text documents of country's PTAs. 
Table 14b Status of commitments for Modes 1, 2, and 3 made by China under GATS and the ChinaPakistan PTA (\%)

\begin{tabular}{|c|c|c|c|c|c|c|c|c|c|}
\hline \multirow[b]{3}{*}{ Country } & \multirow[b]{3}{*}{ Service Sector } & \multicolumn{4}{|c|}{ GATS } & \multicolumn{4}{|c|}{ China-Pakistan } \\
\hline & & \multirow[b]{2}{*}{ M1 } & \multirow[b]{2}{*}{ M2 } & \multicolumn{2}{|c|}{ M3 } & \multirow[b]{2}{*}{ M1 } & \multirow[b]{2}{*}{ M2 } & \multicolumn{2}{|r|}{ M3 } \\
\hline & & & & $\begin{array}{c}\text { No } \\
\text { Restric } \\
\text { tion }\end{array}$ & $\begin{array}{c}\text { Partial } \\
\text { Commit } \\
\text { ment }\end{array}$ & & & $\begin{array}{l}\text { No } \\
\text { Restri } \\
\text { ction }\end{array}$ & $\begin{array}{c}\text { Partial } \\
\text { Commitme } \\
\text { nt }\end{array}$ \\
\hline \multirow{11}{*}{ China } & Business Services & 95.45 & 95.45 & 13.64 & 86.36 & 67.74 & 74.19 & 0.54 & 80.65 \\
\hline & $\begin{array}{l}\text { Communication } \\
\text { Services }\end{array}$ & 72.73 & 100.00 & 0.00 & 100.00 & 23.08 & 69.23 & 23.08 & 76.92 \\
\hline & $\begin{array}{l}\text { Distribution } \\
\text { Services }\end{array}$ & 60.00 & 100.00 & 0.00 & 100.00 & 0.00 & $\begin{array}{r}100.0 \\
0 \\
\end{array}$ & 0.00 & 100.00 \\
\hline & $\begin{array}{l}\text { Construction } \\
\text { Services }\end{array}$ & 100.00 & 100.00 & 0.00 & 100.00 & 40.00 & 80.00 & 60.00 & 40.00 \\
\hline & $\begin{array}{l}\text { Transport } \\
\text { Services }\end{array}$ & 41.67 & 100.00 & 9.33 & 91.67 & 66.67 & 60.00 & 40.00 & 60.00 \\
\hline & $\begin{array}{l}\text { Financial } \\
\text { Services } \\
\end{array}$ & 92.31 & 100.00 & 15.38 & 84.62 & 5.27 & 89.47 & 15.79 & 84.21 \\
\hline & Tourism Services & 100.00 & 100.00 & 0.00 & 100.00 & 100.0 & 100.0 & 0.00 & 100.00 \\
\hline & $\begin{array}{l}\text { Education } \\
\text { Services }\end{array}$ & 100.00 & 100.00 & 0.00 & 100.00 & 0.00 & 100.0 & 0.00 & 100.00 \\
\hline & $\begin{array}{l}\text { Environment } \\
\text { Services }\end{array}$ & 100.00 & 100.00 & 0.00 & 100.00 & 0.00 & 100.0 & 0.00 & 100.00 \\
\hline & Health Services & & & & & 0.00 & 100.0 & 0.00 & 100.00 \\
\hline & $\begin{array}{l}\text { Recreational } \\
\text { Services }\end{array}$ & & & & & 100.0 & 100.0 & 100.0 & 0.00 \\
\hline
\end{tabular}

Source: Author's calculations based on country's GATS commitments available at the WTO website (www.wto.org) and text documents of country's PTAs.

No clear pattern emerges in the modal distribution of commitments with regard to the development status of the countries forming the PTAs. Some developing countries, like India, appear to be more proactive in their liberalization intent than other developing countries. Some developed countries appear to be less willing to commit under PTAs than under the GATS in certain services. Hence, it appears that PTAs may be governed by their own strategic dynamics among the partner countries and that the GATS need not serve as a reference point in terms of signalling willingness to liberalize sectors under the PTAs. The tradeoffs in PTAs may be different from those under the GATS, resulting in differences in the scope and depth of liberalization undertaken.

\section{Autonomous versus preferential liberalization in services}

It is also worth examining how the commitments made by these countries under their PTAs compare to their unilateral liberalization in selected services. Tables 15 to 19 highlight the foreign direct investment (FDI) policies of some of the countries under discussion, for important sectors such as banking, telecommunications, and selected business services. A quick comparison of the unilateral and preferential liberalization stances with respect to FDI (mode 3) indicates that countries have gone further with liberalization on an autonomous basis. In some services, countries have opened up to 100 per cent FDI 
while they have made partial commitments in mode 3 under the PTAs. This is true for both developed and developing countries. Moreover, in terms of the depth of the commitments made, the PTA commitments tend to be more restrictive than the unilateral policies for FDI.

Table $15 \quad$ Key features of mode 3 liberalization for selected services in India

\begin{tabular}{|c|c|c|}
\hline $\begin{array}{l}\text { Service } \\
\text { Sector }\end{array}$ & FDI Openness & Conditions \\
\hline Banking & $\begin{array}{l}74 \% \text { including } \\
\text { investment by } \\
\text { foreign } \\
\text { institutional } \\
\text { investors (FIIs) } \\
\text { Automatic up } \\
\text { to } 49 \% \\
\text { Government } \\
\text { route beyond } \\
49 \% \text { and up to } \\
74 \%\end{array}$ & $\begin{array}{l}\text { (a) Foreign banks will be permitted either to have branches or subsidiaries but not } \\
\text { both. } \\
\text { (b) Foreign banks regulated by banking supervisory authority in the home country } \\
\text { and meeting Reserve Bank's licensing criteria will be allowed to hold } 100 \text { per } \\
\text { cent paid up capital to enable them to set up a wholly-owned subsidiary in India. } \\
\text { (c) At present there is a limit of } 10 \text { per cent on voting rights in respect of banking } \\
\text { companies. }\end{array}$ \\
\hline Insurance & $\begin{array}{l}26 \%, \\
\text { automatic }\end{array}$ & $\begin{array}{l}\text { (a) FDI in the insurance sector, as prescribed in the Insurance Act, 1999, is } \\
\text { allowed under the automatic route. } \\
\text { (b) This will be subject to the condition that companies bringing in FDI shall } \\
\text { obtain the necessary licence from the Insurance Regulatory \& Development } \\
\text { Authority for undertaking insurance activities. }\end{array}$ \\
\hline Telecom & $\begin{array}{l}74 \%, \\
\text { Automatic up } \\
\text { to } 49 \% \\
\text { Government } \\
\text { route beyond } \\
49 \% \text { and up to } \\
74 \%\end{array}$ & $\begin{array}{l}\text { (a) FDI shall be subject to the laws of India and not the laws of the foreign } \\
\text { country or countries. } \\
\text { (b) The Chief Officer in charge of technical network operations and the Chief } \\
\text { Security Officer should be a resident Indian citizen. } \\
\text { (c) The officers/officials of the licensee companies dealing with the lawful } \\
\text { interception of messages will be resident Indian citizens. } \\
\text { (d) The majority of Directors on the Board of the company shall be Indian } \\
\text { citizens. }\end{array}$ \\
\hline Legal & Not Allowed & $\begin{array}{l}\text { India's proposal to the WTO, asking it to allow a } 26 \% \text { FDI in legal services, was } \\
\text { dropped in } 2005 \text { due to resistance from the Law Minister and the politically- } \\
\text { connected legal fraternity }\end{array}$ \\
\hline Accountancy & Not Allowed & \\
\hline
\end{tabular}

Source: DIP, Govt of India, Consolidated FDI Policy 2010,

http://dipp.gov.in/FDI_Circular/FDI_Circular_02of2010.pdf 


\begin{tabular}{|l|l|l|}
\hline $\begin{array}{l}\text { Service } \\
\text { Sector }\end{array}$ & $\begin{array}{l}\text { FDI } \\
\text { Openness }\end{array}$ & Conditions \\
\hline Banking & $100 \%$ allowed & Minimum investment requirements are higher in financial services \\
\hline Telecom & $100 \%$ allowed & Minimum investment of US\$ 0.15 Million \\
\hline Legal Services & $100 \%$ allowed & \\
\hline
\end{tabular}

Source: 'Barriers to foreign direct investment in services, in South Asia' , http://www.centad.org/relatedinfo21.asp and Board of Investment Pakistan website www.pakboi.gov.pk

Table 17 Key features of autonomous liberalization by China in selected services

\begin{tabular}{|l|l|l|}
\hline $\begin{array}{l}\text { Service } \\
\text { Sector }\end{array}$ & $\begin{array}{l}\text { FDI } \\
\text { Openness }\end{array}$ & Conditions \\
\hline Banking & $\begin{array}{l}\text { Following its accession to the WTO, China has faithfully honoured its WTO } \\
\text { commitments and taken a series of opening-up measures on its own initiative. The } \\
\text { foreign banks are encouraged to forge business and equity partnerships with the local } \\
\text { banks, and thus become an important component of the Chinese banking sector. It is } \\
\text { provided in relevant regulations that a Chinese branch of a foreign bank, a wholly } \\
\text { foreign-funded bank or a joint-venture bank is defined as an operational foreign- } \\
\text { funded bank. Subject to approval, its permitted scope of business covers deposit- } \\
\text { taking, loan-making, clearing, custodian services and insurance agency business. } \\
\text { Additionally, such a bank can apply to conduct local currency business as long as it is } \\
\text { in business and profitable for a certain period of time and has fulfilled some other } \\
\text { prudential requirements. At the same time, the foreign-funded banks are allowed to } \\
\text { engage in derivatives trading, QFII custodian services, personal wealth management, } \\
\text { offshore banking services on an agency basis (QDII), electronic banking, etc. In } \\
\text { general, the range of products and services offered by foreign-funded banks has } \\
\text { expanded over the years. The foreign-funded banks are now permitted to engage in } \\
\text { more than 100 categories of business activities. The new Regulations have fully } \\
\text { embodied China's commitments to opening up the banking sector in an all-round } \\
\text { manner, and have removed all the non-prudential restrictions on foreign-funded } \\
\text { banks. According to the new Regulations, a foreign bank is allowed to choose the } \\
\text { form of presence in China based on its business strategies and on a voluntary basis. In } \\
\text { line with the international practices, the foreign-funded banks incorporated in China } \\
\text { are allowed to conduct wholesale and retail RMB business, and will be regulated } \\
\text { under the same supervisory standards as the Chinese banks. In other words, they } \\
\text { enjoy full national treatment. The new Regulations encourages foreign banks to } \\
\text { establish or convert their branches into locally incorporated subsidiaries, while } \\
\text { placing certain restrictions on the retail business conducted by the Chinese branches } \\
\text { of foreign banks. }\end{array}$ \\
\hline
\end{tabular}




\begin{tabular}{|l|l|l|}
\hline Telecom & Allowed & $\begin{array}{l}\text { Regardless of basic or value-added telecom services, the regulations prohibit the } \\
\text { establishment of a foreign company that consists of only foreign capital. Foreign } \\
\text { capital that enters China's telecom service areas must be part of a joint venture } \\
\text { with Chinese capital, and foreign investment in the joint venture cannot exceed } \\
49 \% \text { in fixed-line, or 50\% in wireless and value-added telecom services. And } \\
\text { investment of foreign capital is allowed within the confined areas of telecom } \\
\text { service, but is not allowed to be an independent actor. }\end{array}$ \\
\hline
\end{tabular}

Source: Background Information for the Regulations of the People's Republic of China on Administration of Foreign-funded Banks, China Banking Regulatory Commission: http://www.cbrc.gov.cn/chinese/home/jsp/docView.jsp?docID=2869

Regulatory Politics in China’s Telecommunications Service Industry, http://regulation.upf.edu/utrecht-08papers/yyeo.pdf

Table $18 \quad$ Key features of autonomous liberalization by Korea in selected services

\begin{tabular}{|l|l|l|}
\hline $\begin{array}{l}\text { Service } \\
\text { Sector }\end{array}$ & $\begin{array}{l}\text { FDI } \\
\text { Openness }\end{array}$ & Conditions \\
\hline Banking & $\begin{array}{l}100 \% \\
\text { Allowed }\end{array}$ & $\begin{array}{l}\text { The capital structure, entry and exit regulations are different for branches. } \\
\text { Approval of the Financial Supervisory Commission is needed when foreign } \\
\text { ownership stakes exceed } 10 \%, 25 \%, \text { and } 33 \% \text { up to } 100 \% .\end{array}$ \\
\hline Telecom & Allowed & Foreigners can be largest shareholders in Korea Telecom \\
\hline
\end{tabular}

Source: Financial Sector De-Regulation in Emerging Asia: Focus on Foreign Bank Entry,

http://www.freewebs.com/rrajan1/bankentry.pdf

FDI in Telecommunications Services in Asia, http://www.tif.trpc.com.hk/papers/2004/fdi_asia_telecoms.pdf

Table 19 Key features of autonomous liberalization by Singapore in selected services

\begin{tabular}{|l|l|l|}
\hline $\begin{array}{l}\text { Service } \\
\text { Sector }\end{array}$ & $\begin{array}{l}\text { FDI } \\
\text { Openness }\end{array}$ & Conditions \\
\hline Banking & Allowed & \\
\hline Telecom & Allowed & $\begin{array}{l}\text { In recognition of the important contribution of foreign investment to the } \\
\text { development of the economy, the few restrictions on inward foreign investment } \\
\text { are limited to broadcasting, the domestic news media, retail banking, legal and } \\
\text { other professional services, and property ownership. }\end{array}$ \\
\hline Legal & & \\
\hline
\end{tabular}

Source: WTO Trade Policy Review: Singapore

http://www.philexport.ph/policy/wto/businessbriefingvol9 tpr_singapore.pdf 
Table $20 \quad$ Key features of autonomous liberalization by Japan in selected services

\begin{tabular}{|l|l|l|}
\hline $\begin{array}{l}\text { Service } \\
\text { Sector }\end{array}$ & $\begin{array}{l}\text { FDI } \\
\text { Openness }\end{array}$ & Conditions \\
\hline Telecom & Allowed & $\begin{array}{l}\text { Market access in telecommunications sector open to foreign participation. No } \\
\text { limitations on number of providers of basic services and value added } \\
\text { services. Foreign capital investment unrestricted except for 33\% limit on } \\
\text { NTT stock holdings. National treatment commitment under GATS. }\end{array}$ \\
\hline
\end{tabular}

Source: Trade in Telecommunications Services Experiences of Australia, Japan and Singapore under WTO

Agreements, http://www.unescap.org/tid/mtg/ituwtoesc_s52.pdf

Overall one finds that the scope and degree of liberalization is greatest at the autonomous level, followed by liberalization under PTAs, with the least liberalization being undertaken at the multilateral level. Hence, in effect, what matters most is the liberalization undertaken unilaterally as RTAs either bind the status quo or fall short of binding the status quo.

\section{Summary of findings}

The analysis of the 8 selected Asian PTAs offers several insights. The analysis suggests that the real value of PTAs may not lie in extending services liberalization. Although the PTAs do extend the scope of commitments in terms of number of sectors and subsectors in which commitments are made by the countries, they do not for the most part involve more liberal commitments within subsectors and in the various modes. While some additional liberalization may be offered, particularly in mode 3 , this is not uniformly true and similar restrictions continue to apply under the multilateral and the preferential commitments. Further, liberalization under PTAs still tends to fall short of the autonomous liberalization undertaken. Hence, the Asian PTAs do not necessarily enable deeper liberalization within sectors and modes.

The analysis also reveals that there is no significant improvement over the GATS in terms of the architecture of the services chapter and the provisions therein. Many PTAs almost mirror the services provisions of the GATS while a few include additional provisions, refer to additional issues, elaborate further on the scope of certain provisions, and draw linkages with other parts of the PTA texts. However, there is no significant development in terms of the content of key disciplines or in terms of strengthening of institutional mechanisms in the services chapters. They are stronger on intent than on substantive content.

However, the real improvement is in terms of the overall architecture of the agreement, i.e., the additional chapters and annexes which go into considerable detail on a variety of cross-cutting issues and sectors that impinge on services trade. In particular, cross-cutting issues of investment and mobility of persons are covered in considerable detail relative to the GATS, along with references to institutional mechanisms for operationalizing the provisions such as through elaborate dispute settlement mechanisms. The additional annexes cover many sectors and new age issues which are absent from the GATS, including 
coverage of certain services which have proven difficult to liberalize under the WTO. Hence, the value of the PTAs is more in terms of (a) making progress in important areas such as investment and labour mobility; (b) developing disciplines and frameworks not necessarily specific to services but in a variety of other areas which have a bearing on services; and (c) enabling the coverage of new issues. Moreover, the differences that exist between PTAs with regard to the provisions which have a direct or indirect bearing on services suggest that such agreements enable countries to negotiate strategically and to frame the PTA texts and commitments in a manner that addresses specific interests and sensitivities associated with different partner countries.

Some broad generalizations can also be made about the nature of countries involved and the nature of the PTA texts and commitments. In general, the scope of commitments is greater for developed countries under the GATS and under the PTAs. However, developing countries tend to show more expansion in scope under PTAs relative to the GATS, partly because they have scheduled fewer sectors and subsectors than have developed countries under the GATS. Some developing countries such as India emerge as being significantly more proactive in their liberalization stance and their willingness to negotiate more comprehensively through additional annexes and extra detail in areas of strategic interest such as movement of natural persons. But overall, there is no consistent pattern with regard to the typology of PTAs either in terms of the nature of commitments or in terms of their modal distribution. Where some distinction can be made among the various kinds of PTAs is in terms of the framework and issues covered through additional chapters and annexes. North-North agreements tend to cover some of the more difficult issues such as government procurement, while North-South agreements have a focus on issues such as recognition of qualifications which relate to the importance of mode 4 in North-South services trade. South-South agreements tend to focus on institutional cooperation and establishment of mechanisms, reflecting the need for strengthening capacity and institution building in these countries. But there is sufficient diversity even among the various types of PTAs and all North-North or North-South, or South-South agreements do not follow a uniform pattern, indicating that the negotiating dynamics vary by partner countries. 


\section{References}

Abeysinghe, S., "Structure and Content of the draft Services Chapter of India-Sri Lanka CEPA: To what extent does it go beyond GATS in promoting transparency, credibility and liberalization of services?," Masters Thesis, World Trade Institute, September 30, 2010

ADB Asia Regional Integration Data Center Database for FTAs, http://aric.adb.org/FTAbyCountryAll.php

Adlung, R. and P. Morrison, "Less than the GATS: Negative Preferences in Regional Services Agreements", mimeo, November 27, 2009

ASEAN Secretariat, China-ASEAN Free Trade Agreement, http://www.aseansec.org/16646.htm

Board of Investment Sri Lanka, www.boi.lk

Board of Investment Pakistan, www.pakboi.gov.pk

Carzaniga, A., "A Warmer welcome? Access for natural persons under PTAs”, in Marchetti, J. and M. Roy (eds.), Opening Markets for Trade in Services: Countries and Sectors in Bilateral and WTO Negotiations, Cambridge, Cambridge University Press, 2008, pp. 61-112

Centre for Trade and Development, "arriers to foreign direct investment in services, in South Asia" http://www.centad.org/relatedinfo21.asp

China Banking Regulatory Commission, Background Information for the Regulations of the People's Republic of China on Administration of Foreign-funded Banks, http://www.cbrc.gov.cn/chinese/home/jsp/docView.jsp?docID=2869

Dee, P. and J. Gali, "The trade and investment effects of preferential trading arrangements", prepared for the Fourteenth Annual East Asian Seminar on Economics, Taipei, September 2003

Department of Industrial Policy and Promotion, Govt of India, "Consolidated FDI Policy 2010", http://dipp.gov.in/FDI_Circular/FDI_Circular_02of2010.pdf

Fink, C. and M. Molinuevo, "East Asian FTAs in Services: Roaring Tigers or Timid Pandas", East Asia and Pacific Region, Report No. 40175, The World Bank, 2007

Government of India, Ministry of Commerce, India-Korea Comprehensive Economic Partnership Agreement, http://commerce.nic.in/trade/INDIA\%20KOREA\%20CEPA\%202009.pdf

Government of India, Ministry of Commerce, India-Singapore Comprehensive Economic Cooperation Agreement, http://commerce.nic.in/ceca/toc.htm

Government of Japan, Japan-Singapore Economic Partnership Agreement, http://www.mofa.go.jp/region/asia-paci/singapore/jsepa.html

Government of Japan, Japan-Philippines Economic Partnership Agreement, http://www.mofa.go.jp/region/asia-paci/philippine/epa0609/main.pdf

Government of Pakistan, China-Pakistan Agreement on Trade in Services, http://www.commerce.gov.pk/PCFTA-S/Agreement.PDF 
Government of India, Ministry of Commerce, India-Sri Lanka Comprehensive Economic Partnership Agreement, http://commerce.nic.in/trade/international ta_current_details.asp\#b22

Gopalan, S. and R. Rajan, "Financial Sector De-Regulation in Emerging Asia: Focus on Foreign Bank Entry", Journal of World Investment and Trade, 14:12, 2010

http://www.freewebs.com/rrajan1/bankentry.pdf

Marchetti, J. and M. Roy, "Services Liberalization in the WTO and in PTAs", in Marchetti, J. and M. Roy (eds.), Opening Markets for Trade in Services: Countries and Sectors in Bilateral and WTO Negotiations, Cambridge, Cambridge University Press, 2008, pp. 61-112

Mattoo, A. and P. Sauve, "The Preferential Liberalization of Services Trade”, NCCR Trade Regulation Working Paper 2010/13

http://www.wti.org/research/publication/?tx_nccr_pi1\%5Bshow\%5D=97\&cHash=309ad4541e97e8a7b3b $\underline{3 d d 02 d f f 099 d 5}$

Mattoo, A., and P. Sauve, "Regionalism in Services Trade", A Handbook of International Trade in Services, Oxford University Press, New York, 2008

Nag, B. and D. De, “ Services in Regional Trade Agreements: Implications for India”, MPRA, Munich, September 2008, http://mpra.ub.uni-muenchen.de/15871

Roy, M., Marchetti, J. and Lim, "Services Liberalization in the new generation of PTAs: How much further than the GATS", World Trade Review 6 (2), 2007, pp. 1455-93

Thangavelu, S. and S. Abe, "Singapore, India and Japan in the Framework of FTA/EPA Arrangement", Centre for Contemporary Asian Studies, Doshisha University, CCAS Working Paper No. 6, May 2007

UN-ESCAP Trade Agreements database, http://www.unescap.org/tid/aptiad/agg db.aspx

UN-ESCAP, "Trade in Telecommunications Services Experiences of Australia, Japan and Singapore under WTO Agreements", http://www.unescap.org/tid/mtg/ituwtoesc s52.pdf

Ure, J., "FDI in Telecommunications Services in Asia", Kyoto, 2004

http://www.tif.trpc.com.hk/papers/2004/fdi asia telecoms.pdf

USTR, US-Korea Free Trade Agreement, http://www.ustr.gov/trade-agreements/free-tradeagreements/korus-fta

Wignaraja, G. and D. Lazaro, "North-South vs. South-South Asian FTAs: Trends, Compatibilities, and Ways Forward”, UNU-CRIS Working Papers, W-2010/3, 2010

World Bank database, http://data.worldbank.org/indicator/NY.GDP.MKTP.CD

WTO, Individual country GATS commitments, www.wto.org

WTO, Trade Policy Review: Singapore, http://www.philexport.ph/policy/wto/businessbriefingvol9 tpr_singapore.pdf

Yukyong Yeo, Department of Social and Public Administration, City University of Hong Kong, "Regulatory Politics in China's Telecommunications Service Industry", June 2008, http://regulation.upf.edu/utrecht-08-papers/yyeo.pdf 
Appendix A

Status of PTAs for selected countries in Asia

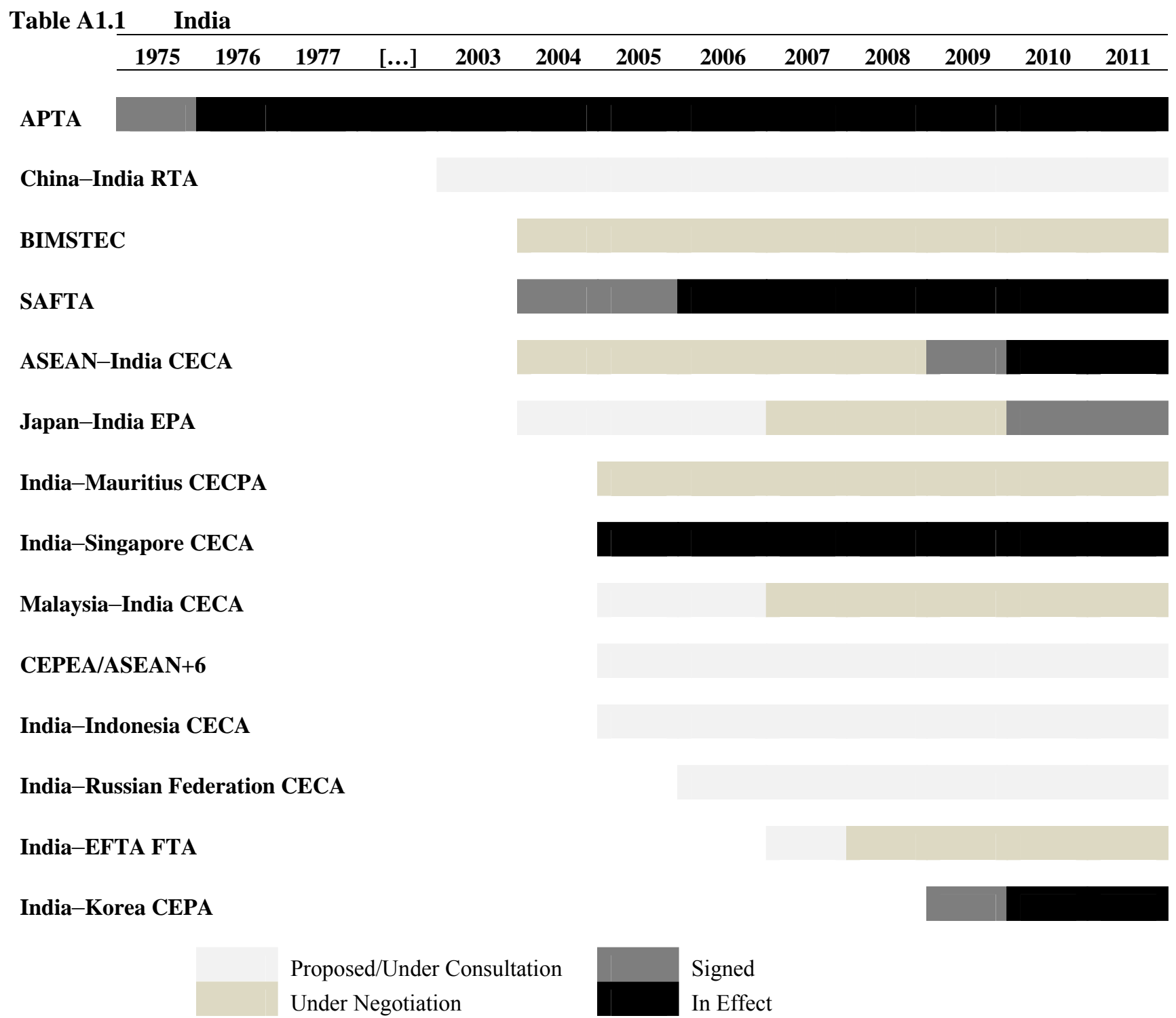

Source: ADB Asia Regional Integration Data Center Database for FTAs available at http://aric.adb.org/FTAbyCountryAll.php and UN-ESCAP Trade Agreements database available at http://www.unescap.org/tid/aptiad/agg_db.aspx 
Table A1.2 Indonesia

\begin{tabular}{llllllllll}
\hline 2002 & 2003 & 2004 & 2005 & 2006 & 2007 & 2008 & 2009 & 2010 & 2011 \\
\hline
\end{tabular}

\section{ASEAN-China CECA}

ASEAN-EU FTA

ASEAN-Korea CECA

ASEAN-India CECA

CEPEA/ASEAN+6

ASEAN- Japan CEP

India-Indonesia CECA

Indonesia-EFTA FTA

ASEAN-ANZ FTA

Japan-Indonesia EPA

Indonesia-Australia FTA

\section{Proposed/Under Consultation \\ Under Negotiation \\ Signed \\ In Effect}

Source: ADB Asia Regional Integration Data Center Database for FTAs available at

http://aric.adb.org/FTAbyCountryAll.php and UN-ESCAP Trade Agreements database available at

http://www.unescap.org/tid/aptiad/agg_db.aspx

Table A1.3 Japan

\begin{tabular}{llllllllllll}
\hline 2000 & 2001 & 2002 & 2003 & 2004 & 2005 & 2006 & 2007 & 2008 & 2009 & 2010 & 2011 \\
\hline
\end{tabular}

Japan-Singapore

EAP

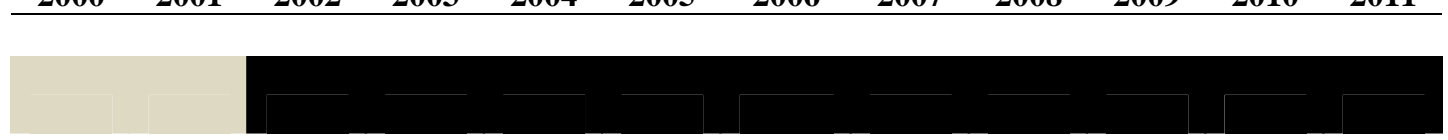

China-Japan-Korea FTA

Japan-Mexico EPA 
Japan-India EPA

Japan-Malaysia EPA

Japan-Thailand EPA

CEPEA/ASEAN+6

ASEAN- Japan CEP

Japan-Australia EPA

Japan-Chile EPA

Japan-Indonesia EPA

Japan-Brunei FTA

Japan-GCC FTA

Japan-Philippines EPA

Japan-Switzerland EPA

Japan-Vietnam EPA

Japan-Korea FTA

Japan-Peru FTA

Proposed/Under Consultation

Under Negotiation
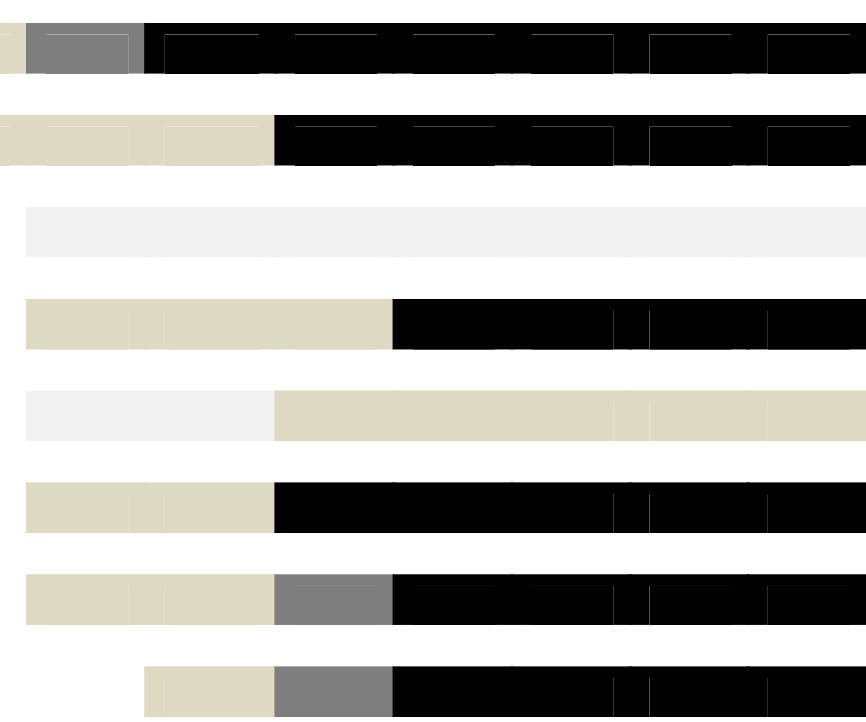


\section{Korea-Canada FTA \\ CEPEA/ASEAN+6 \\ Korea-EFTA FTA \\ China-Korea FTA \\ Australia-Korea FTA \\ Korea-EU FTA \\ Korea-US FTA \\ NZ-Korea CEP \\ Japan-Korea FTA \\ India-Korea CEPA}

\section{Proposed/Under Consultation \\ Under Negotiation \\ Signed \\ In Effect}

Source: ADB Asia Regional Integration Data Center Database for FTAs available at http://aric.adb.org/FTAbyCountryAll.php and UN-ESCAP Trade Agreements database available at http://www.unescap.org/tid/aptiad/agg_db.aspx

Table A1.5 Malaysia

ASEAN-China CECA

\begin{tabular}{llllllllll}
2002 & 2003 & 2004 & 2005 & 2006 & 2007 & 2008 & 2009 & 2010 & 2011 \\
\hline
\end{tabular}

ASEAN-EU FTA

ASEAN-Korea CECA

ASEAN-India CECA

Japan-Malaysia EPA

$+\sqrt{\square+}+\sqrt{\square} \square$

CEPEA/ASEAN+6

ASEAN- Japan CEP

Malaysia-India CECA 
ASEAN-ANZ FTA

Malaysia-Australia FTA

Malaysia-NZ FTA

Malaysia-Pakistan CEPA

US-Malaysia FTA

Trans-Pacific Partnership (TPP)

Proposed/Under Consultation

Under Negotiation

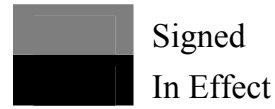

Source: ADB Asia Regional Integration Data Center Database for FTAs available at

http://aric.adb.org/FTAbyCountryAll.php and UN-ESCAP Trade Agreements database available at

http://www.unescap.org/tid/aptiad/agg_db.aspx

Table A1.6

Pakistan

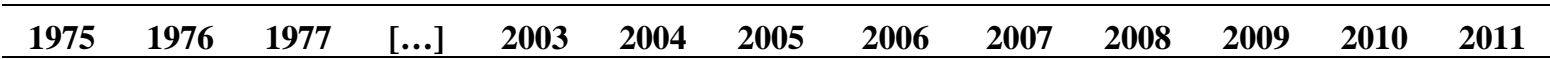

\section{SAFTA}

\section{Malaysia-Pakistan CEPA}

China-Pak Agreement on Trade in Services

\section{Proposed/Under Consultation \\ Under Negotiation}

Signed

In Effect

Source: ADB Asia Regional Integration Data Center Database for FTAs available at http://aric.adb.org/FTAbyCountryAll.php and UN-ESCAP Trade Agreements database available at http://www.unescap.org/tid/aptiad/agg_db.aspx

\section{Table A1.7 Philippines}

\begin{tabular}{llllllllllll}
1998 & {$[\ldots]$} & 2002 & 2003 & 2004 & 2005 & 2006 & 2007 & 2008 & 2009 & 2010 & 2011 \\
\hline
\end{tabular}

US-Philippines

FTA

ASEAN-China CECA

ASEAN-EU FTA 
ASEAN-Korea CECA

ASEAN-India CECA

CEPEA/ASEAN+6

ASEAN- Japan CEP

ASEAN-ANZ FTA

Japan-Philippines EPA

\title{
Proposed/Under Consultation \\ Under Negotiation \\ Signed \\ In Effect
}

Source: ADB Asia Regional Integration Data Center Database for FTAs available at

http://aric.adb.org/FTAbyCountryAll.php and UN-ESCAP Trade Agreements database available at

http://www.unescap.org/tid/aptiad/agg_db.aspx

Table A1.8 Singapore

$\begin{array}{llllllllllll}2000 & 2001 & 2002 & 2003 & 2004 & 2005 & 2006 & 2007 & 2008 & 2009 & 2010 & 2011\end{array}$

US-Singapore FTA

Japan-Singapore EAP

Singapore-Australia FTA

NZ-Singapore CEP

EFTA-Singapore FTA

ASEAN-China CECA

ASEAN-EU FTA

Singapore-Jordan FTA

TPSEPA

ASEAN-Korea CECA

ASEAN-India CECA
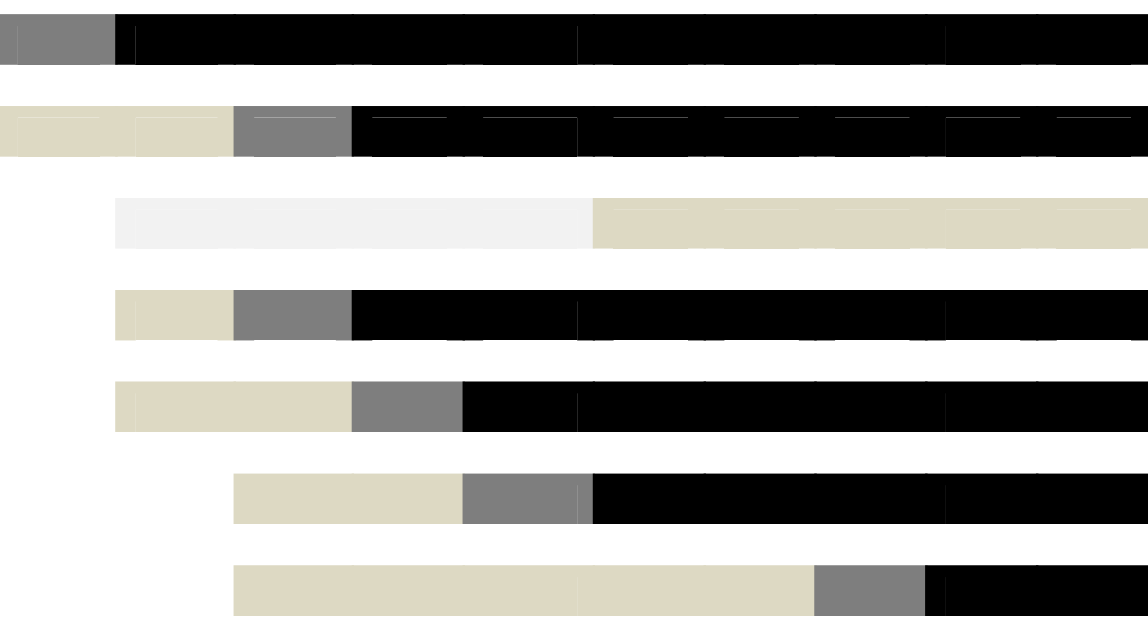

\author{
Korea-Singapore FTA \\ Singapore-Panama FTA \\ Tingapore-Panama
}




\section{CEPEA/ASEAN+6}

ASEAN- Japan CEP

ASEAN-ANZ FTA

India-Singapore CECA

China-Singapore FTA

Singapore-Peru FTA

GCC-Singapore FTA

Singapore-Costa Rica FTA

Trans-Pacific Partnership (TPP)

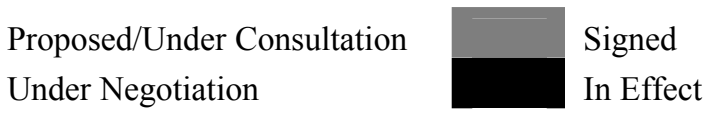

Source: ADB Asia Regional Integration Data Center Database for FTAs available at

http://aric.adb.org/FTAbyCountryAll.php and UN-ESCAP Trade Agreements database available at

http://www.unescap.org/tid/aptiad/agg_db.aspx

Table A1.9 Sri Lanka

\begin{tabular}{lllllllllllll}
1975 & 1976 & 1977 & {$[\ldots]$} & 2003 & 2004 & 2005 & 2006 & 2007 & 2008 & 2009 & 2010 & 2011 \\
\hline
\end{tabular}

APTA

BIMSTEC

SAFTA

\begin{tabular}{l|l} 
Proposed/Under Consultation & Signed \\
Under Negotiation & In Effect
\end{tabular}

Source: ADB Asia Regional Integration Data Center Database for FTAs available at

http://aric.adb.org/FTAbyCountryAll.php and UN-ESCAP Trade Agreements database available at http://www.unescap.org/tid/aptiad/agg_db.aspx

Table A1.10 Thailand

\begin{tabular}{llllllllll}
\hline 2002 & 2003 & 2004 & 2005 & 2006 & 2007 & 2008 & 2009 & 2010 & 2011 \\
\hline
\end{tabular}

ASEAN-China CECA

Thailand-Bahrain FTA 


\section{ASEAN-EU FTA}

US-Thailand FTA

ASEAN-Korea CECA

ASEAN-India CECA

BIMSTEC

Japan-Thailand EPA

Thailand-Australia FTA

CEPEA/ASEAN+6

ASEAN- Japan CEP

ASEAN-ANZ FTA

Thailand-NZ CEPA

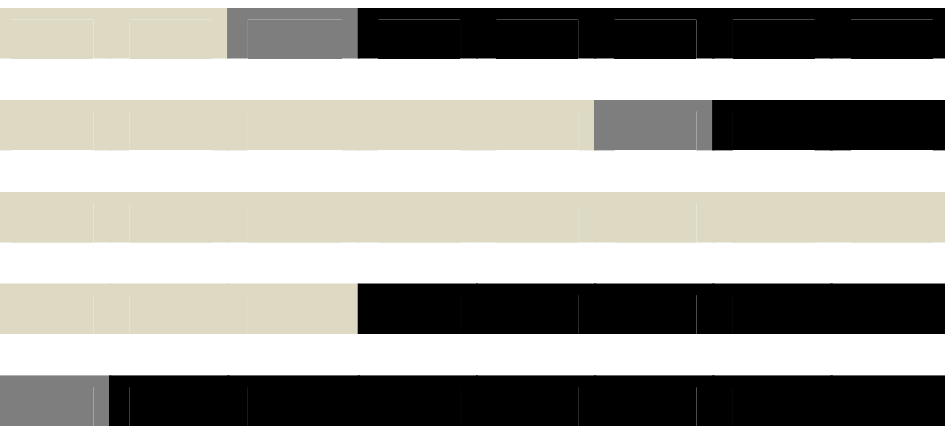

\section{Proposed/Under Consultation \\ Under Negotiation \\ Signed \\ In Effect}

Source: ADB Asia Regional Integration Data Center Database for FTAs available at

http://aric.adb.org/FTAbyCountryAll.php and UN-ESCAP Trade Agreements database available at

http://www.unescap.org/tid/aptiad/agg_db.aspx

Table A1.11 China

\begin{tabular}{lllllllllllll}
\hline 1975 & 1976 & {$[\ldots]$} & 2002 & 2003 & 2004 & 2005 & 2006 & 2007 & 2008 & 2009 & 2010 & 2011 \\
\hline
\end{tabular}

APTA

\section{China-Japan-Korea FTA}

China-Macao CEPA

China-Hong Kong, China FTA

China-India RTA

ASEAN-China CECA

New Zealand-China FTA

CEPEA/ASEAN+6 
China-Australia FTA

China-Chile FTA

China-GCC FTA

China-Iceland FTA

China-Korea FTA

China-Singapore FTA

China-Peru FTA

China-Costa Rica FTA

China-Norway FTA

China-Pak Agreement on Trade in Services

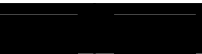

China-Taipei, China ECFA

\section{Proposed/Under Consultation Under Negotiation}

Signed

In Effect

Source: ADB Asia Regional Integration Data Center Database for FTAs available at http://aric.adb.org/FTAbyCountryAll.php and UN-ESCAP Trade Agreements database available at http://www.unescap.org/tid/aptiad/agg_db.aspx

Figure A1.1 Number of South and Southeast Asian country PTAs which include services

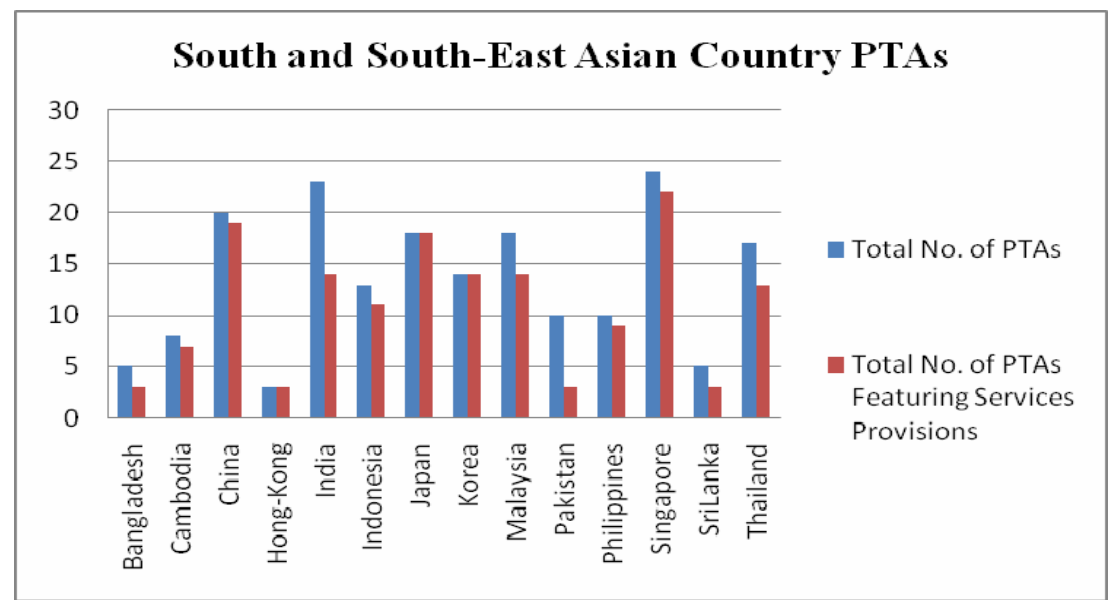

Source: ADB Asia Regional Integration Data Center Database for FTAs available at http://aric.adb.org/FTAbyCountryAll.php and UN-ESCAP Trade Agreements database available at http://www.unescap.org/tid/aptiad/agg_db.aspx 
Figure A1.2 Share of PTAs covering services in total South and Southeast Asian PTAs (\%)

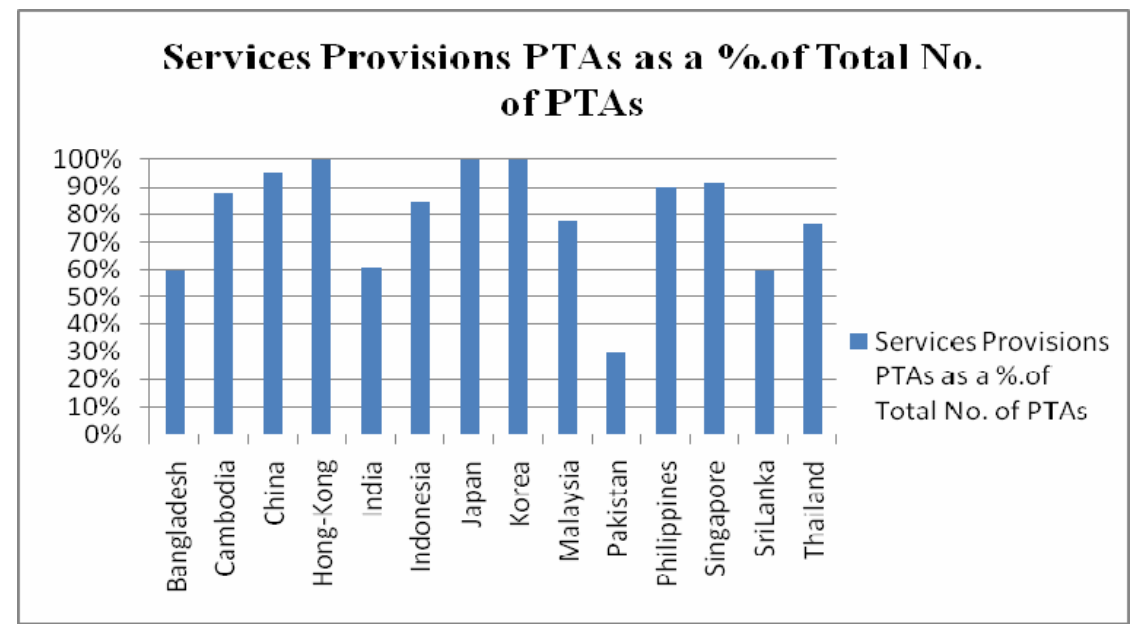

Source: ADB Asia Regional Integration Data Center Database for FTAs available at http://aric.adb.org/FTAbyCountryAll.php and UN-ESCAP Trade Agreements database available at http://www.unescap.org/tid/aptiad/agg db.aspx 
Appendix B

Subsectors Scheduled by Countries under the GATS and under the PTAs

Figure B.1 Subsectors scheduled by India under the GATS, India-Korea CEPA, and IndiaSingapore CECA

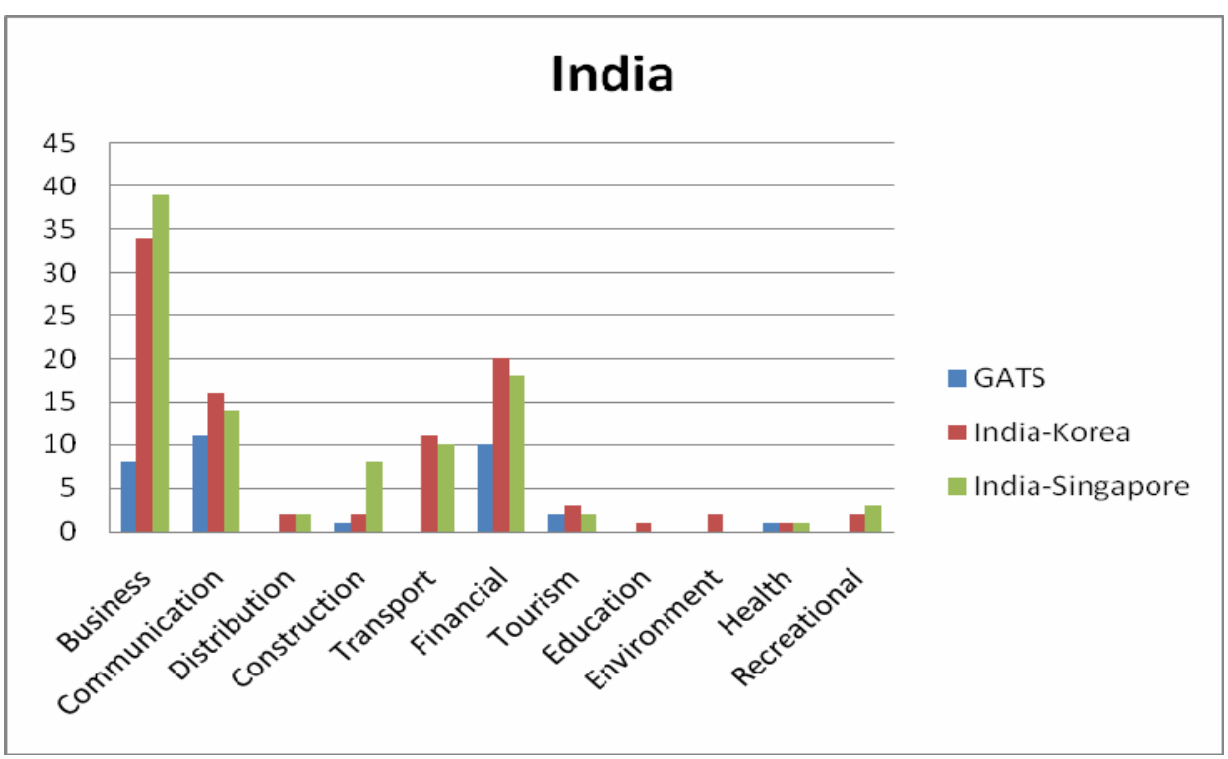

Source: Author's calculations based on country's GATS commitment available at the WTO website (www.wto.org) and text documents of country's PTAs.

Figure B.2 Subsectors scheduled by Korea under the GATS and the India-Korea CEPA

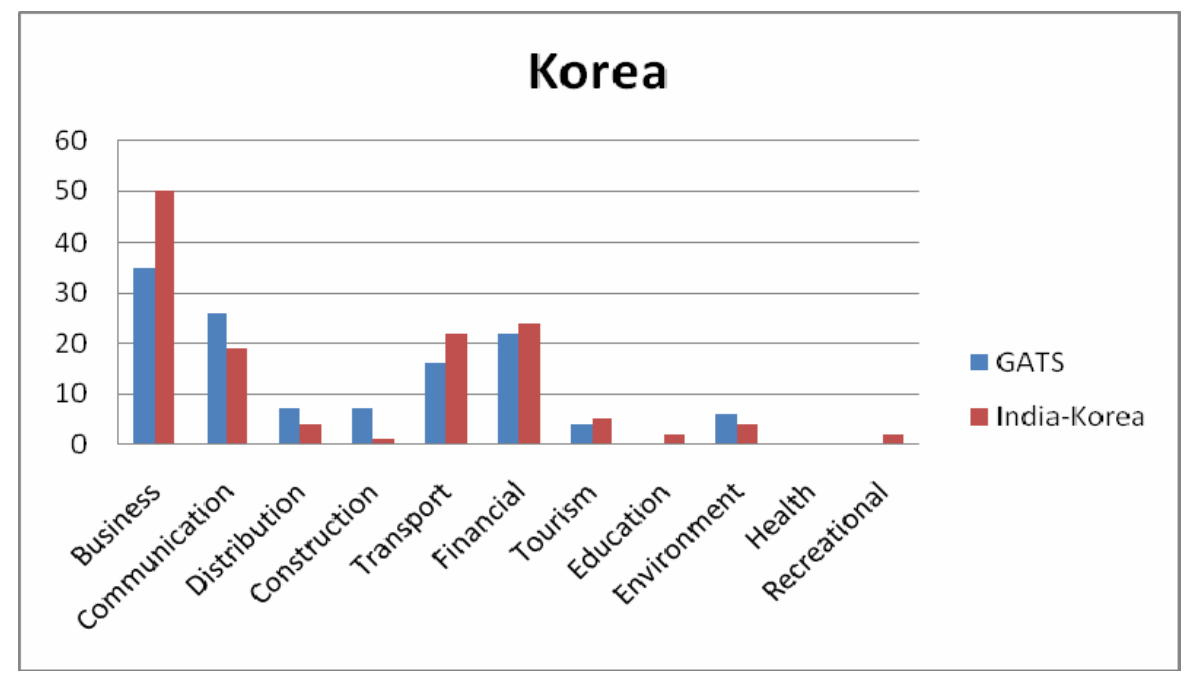

Source: Author's calculations based on country's GATS commitments available at the WTO website (www.wto.org) and text documents of country's PTAs. 
Figure B.4 Subsectors scheduled by Singapore under the GATS, India-Singapore CECA, JapanSingapore CECA, and the China-ASEAN FTA

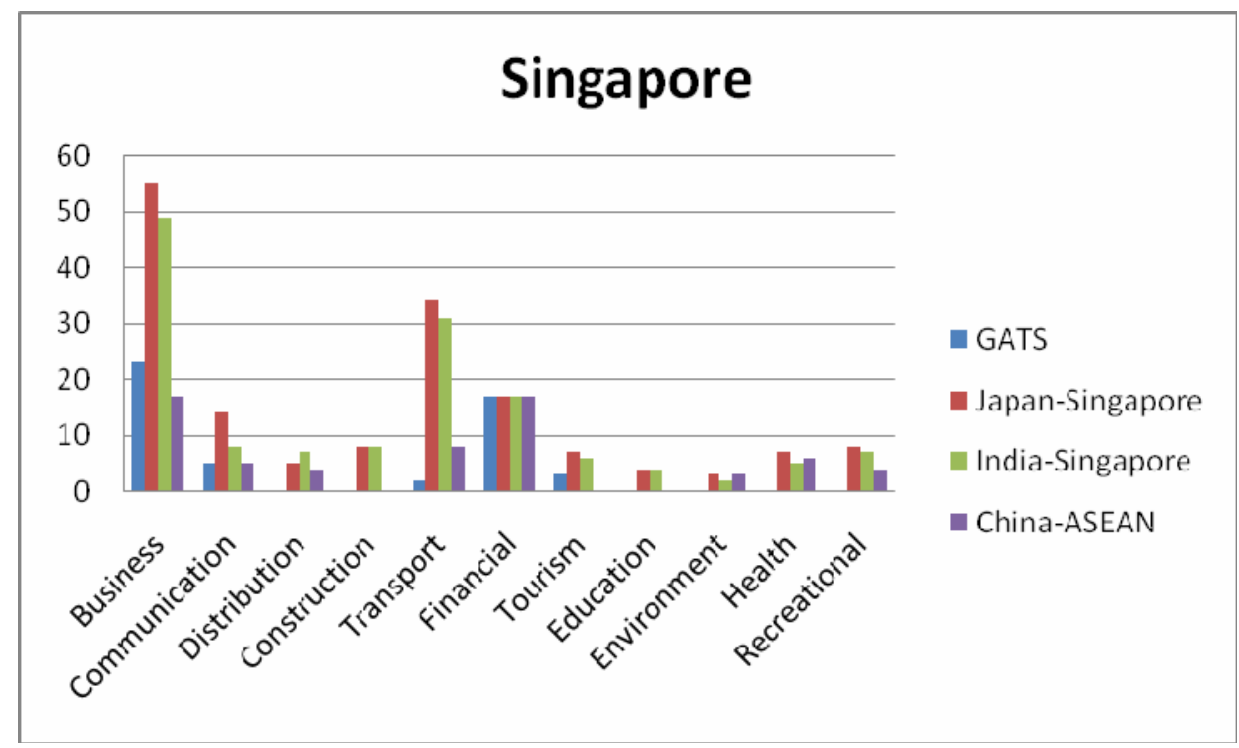

Source: Author's calculations based on country's GATS commitments available at the WTO website (www.wto.org) and text documents of country's PTAs.

Figure B.5 Subsectors scheduled by China under the GATS, China-ASEAN FTA, and the ChinaPakistan FTA

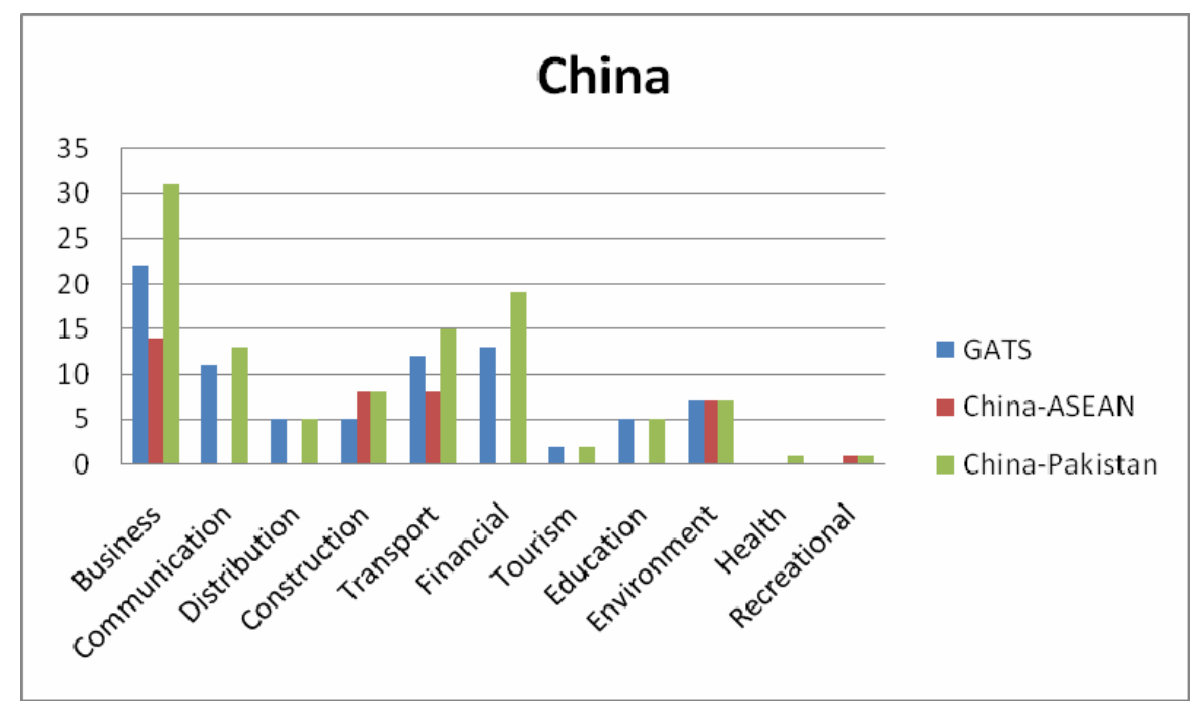

Source: Author's calculations based on country's GATS commitment available at the WTO website (www.wto.org) and text documents of country's PTAs. 


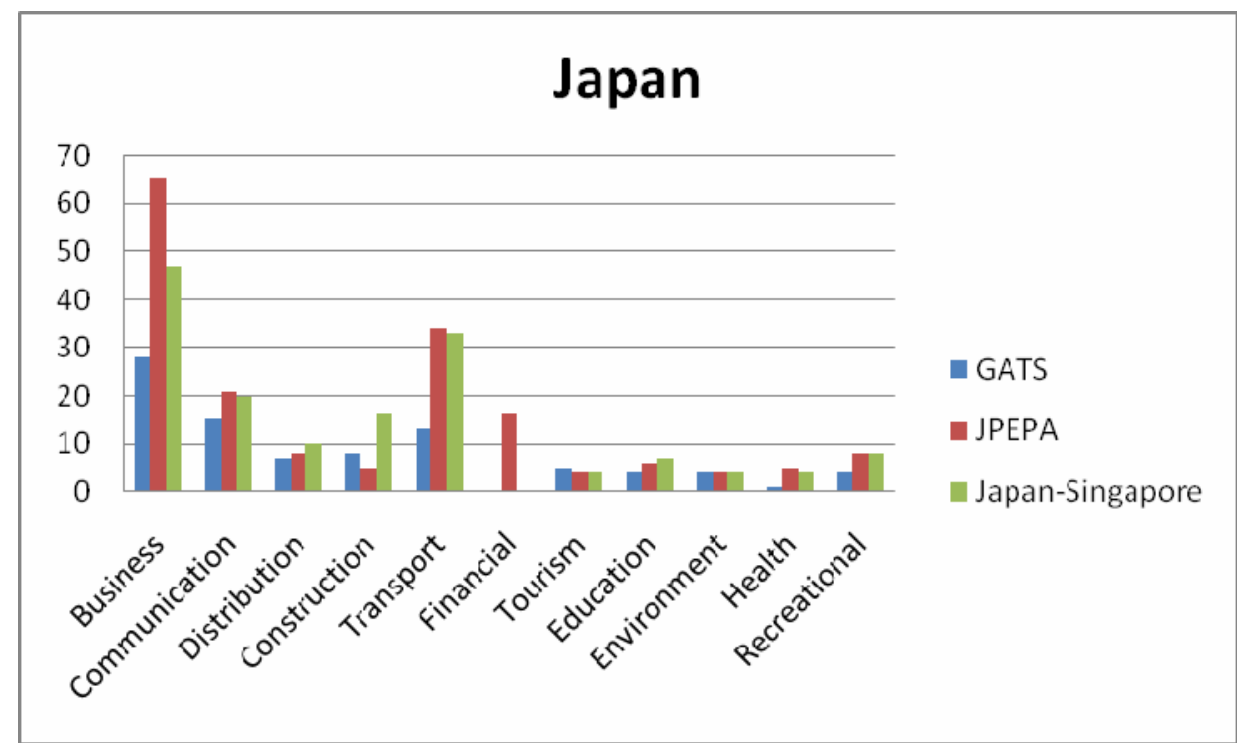

Source: Author's calculations based on country's GATS commitment available at the WTO website (www.wto.org) and text documents of country's PTAs.

Figure B.7 Subsectors scheduled by the Philippines under the GATS, the Japan-Philippines EPA, and the China-ASEAN FTA

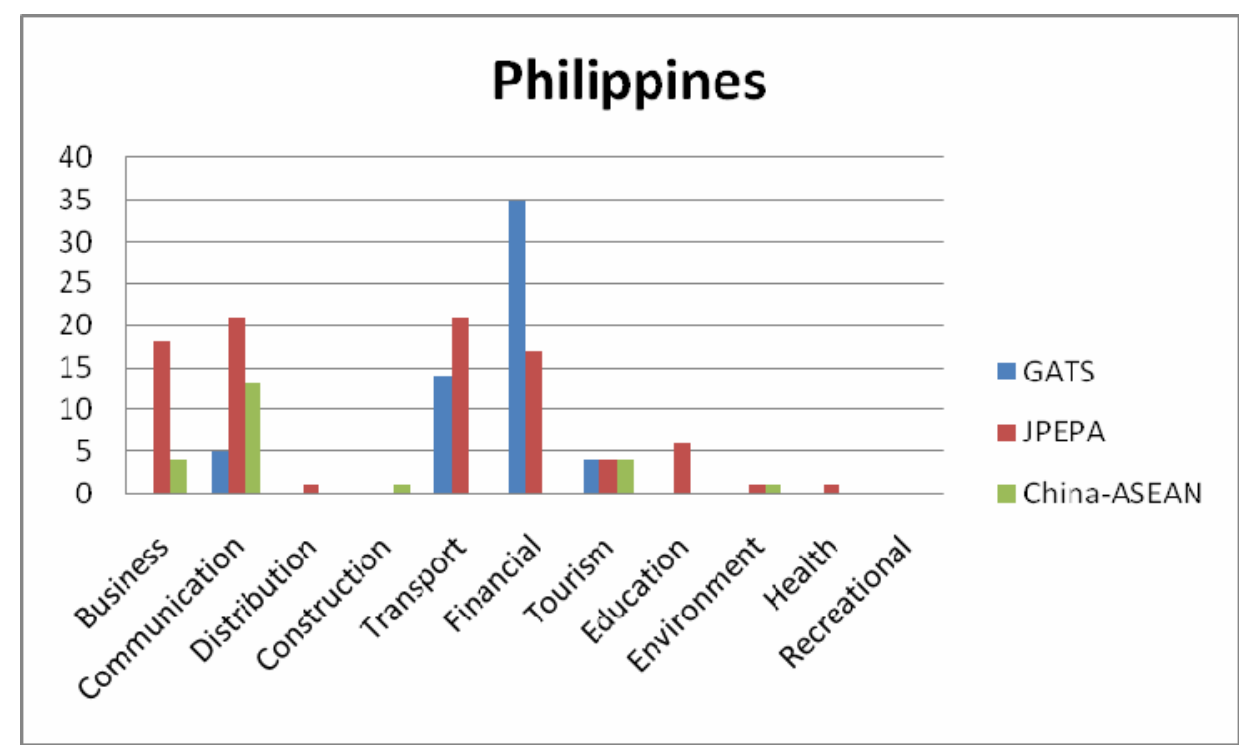

Source: Author's calculations based on country's GATS commitment available at the WTO website (www.wto.org) and text documents of country's PTAs. 
Figure B.8 Subsectors scheduled by Indonesia under the GATS and the China-ASEAN FTA

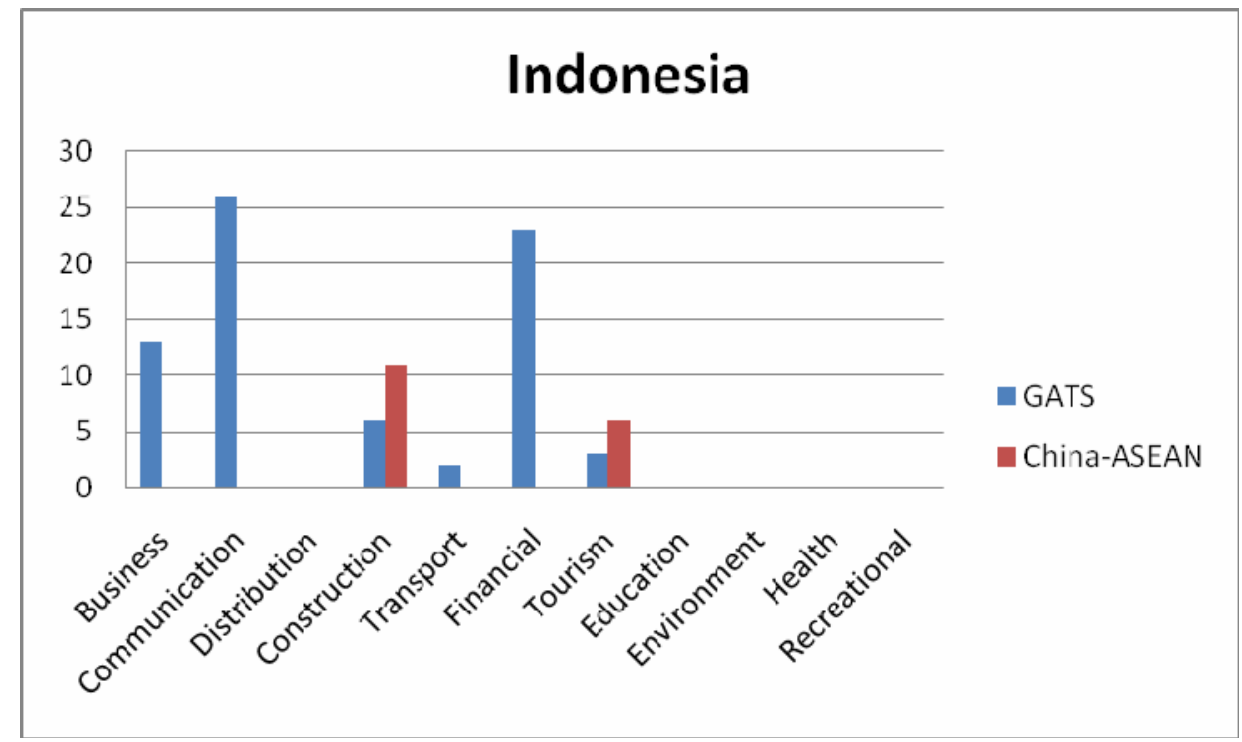

Source: Author's calculations based on country's GATS commitment available at the WTO website (www.wto.org) and text documents of country's PTAs.

Figure B.9 Subsectors scheduled by Malaysia under the GATS and the China-ASEAN FTA

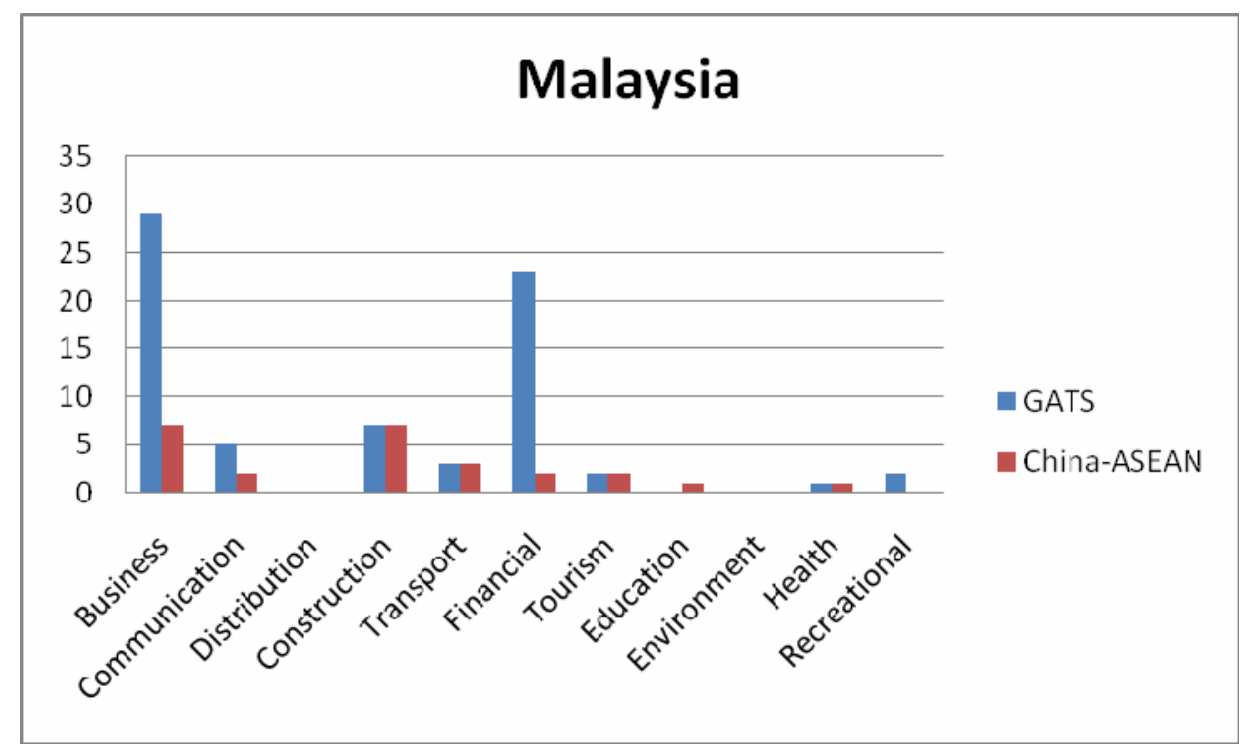

Source: Author's calculations based on country's GATS commitments available at the WTO website (www.wto.org) and text documents of country's PTAs. 
Figure B.10 Subsectors scheduled by Thailand under the GATS and the China-ASEAN FTA

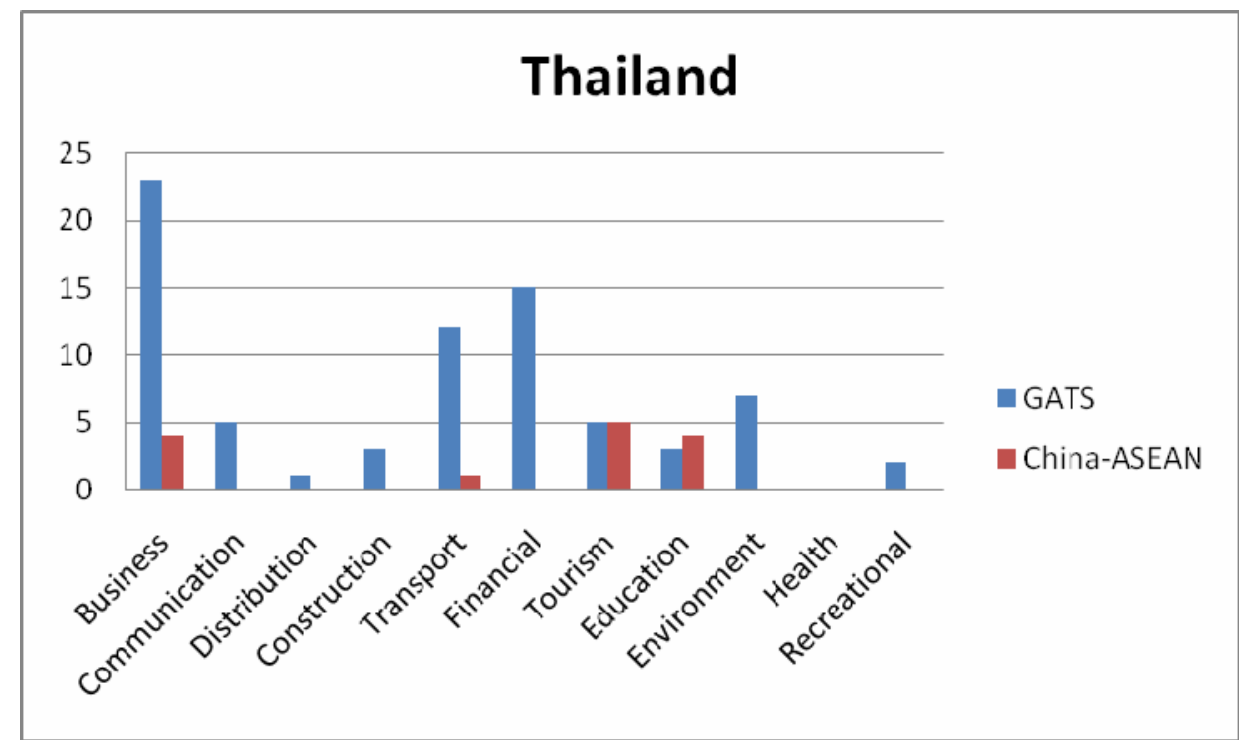

Source: Author's calculations based on country's GATS commitment available at the WTO website (www.wto.org) and text documents of country's PTAs.

Figure B.11 Subsectors scheduled by Pakistan under the GATS and the China-Pakistan FTA

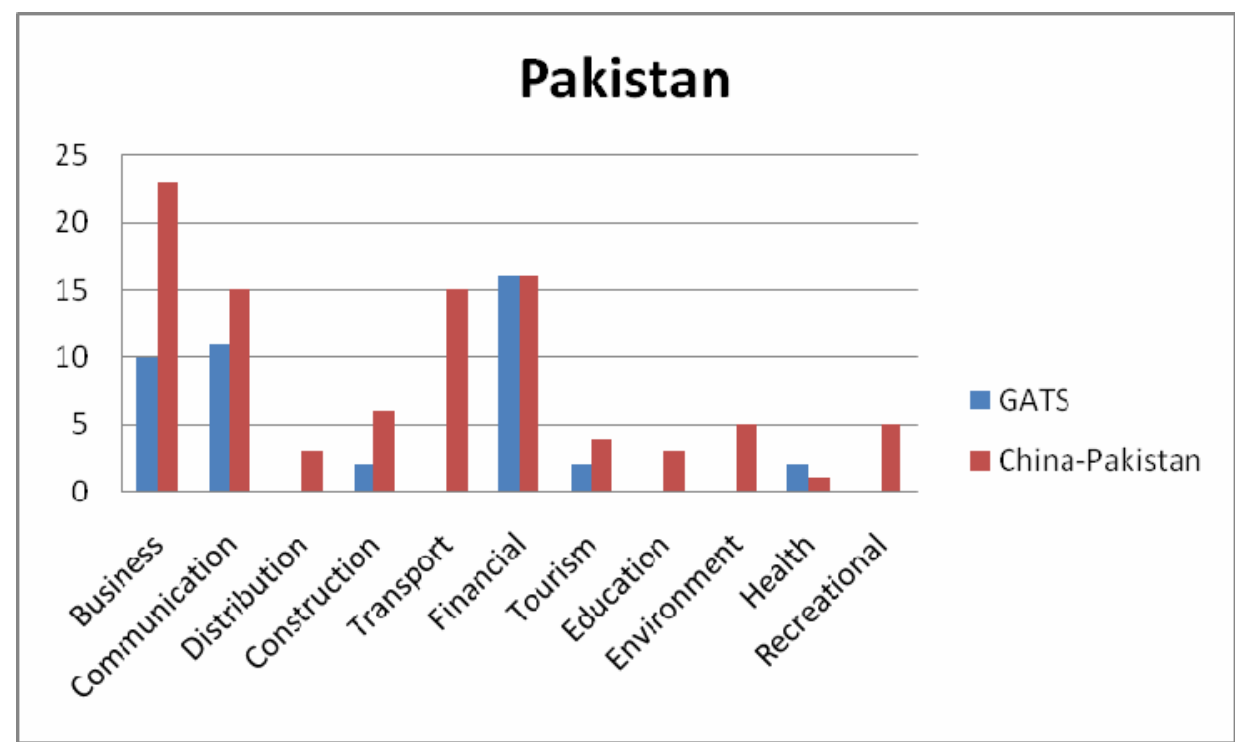

Source: Author's calculations based on country's GATS commitments available at the WTO website (www.wto.org) and text documents of country's PTAs. 
Appendix C

\section{Correlating Commitments in Sectors and Subsectors with Income per Capita}

Figure C.1 Number of sectors in committed under the GATS and GDP per capita at time of commitment for selected countries

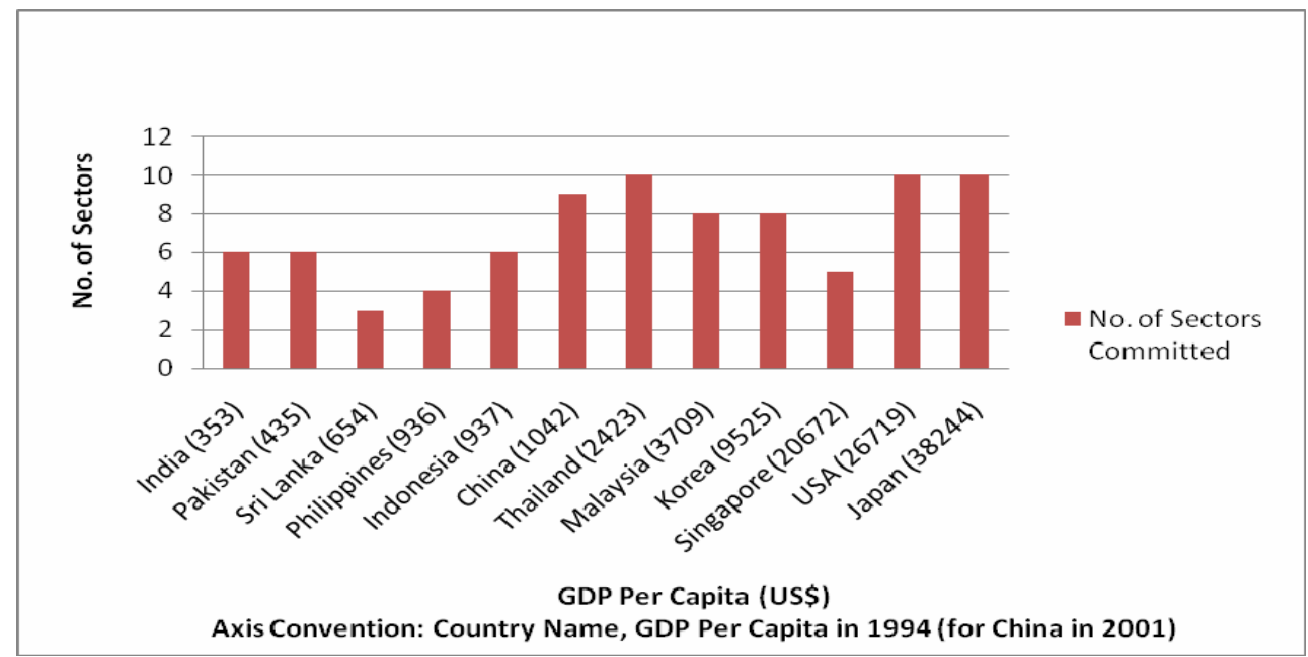

Source: Based on country's GATS commitments available at the WTO website (www.wto.org) and GDP per capita data from http://data.worldbank.org/indicator/NY.GDP.MKTP.CD

Figure C.2 Number of sub-sectors in committed under the GATS and GDP per capita at time of commitment for selected countries

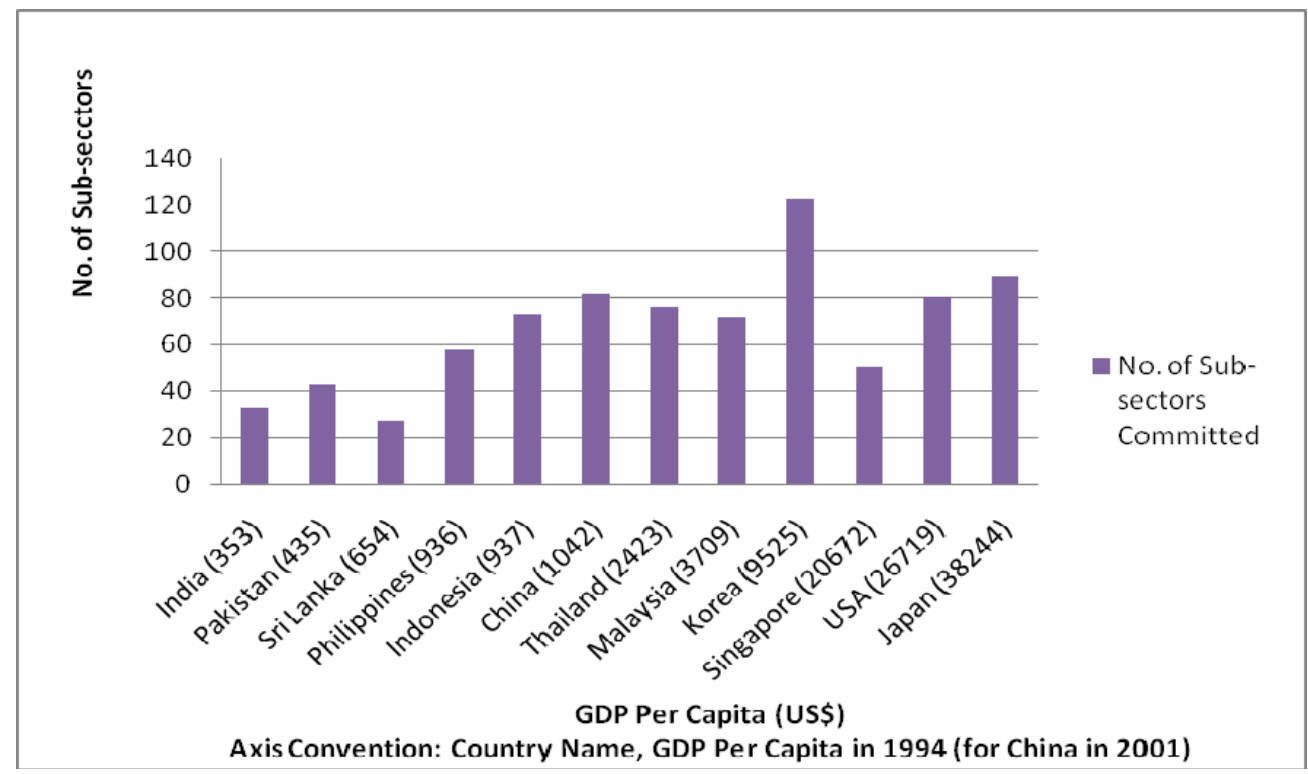

Source: Based on country's GATS commitment available at the WTO website (www.wto.org) and GDP per capita data from http://data.worldbank.org/indicator/NY.GDP.MKTP.CD 
Figure C.3 Number of sectors committed under selected PTAs and GDP per capita at time of commitment for selected countries

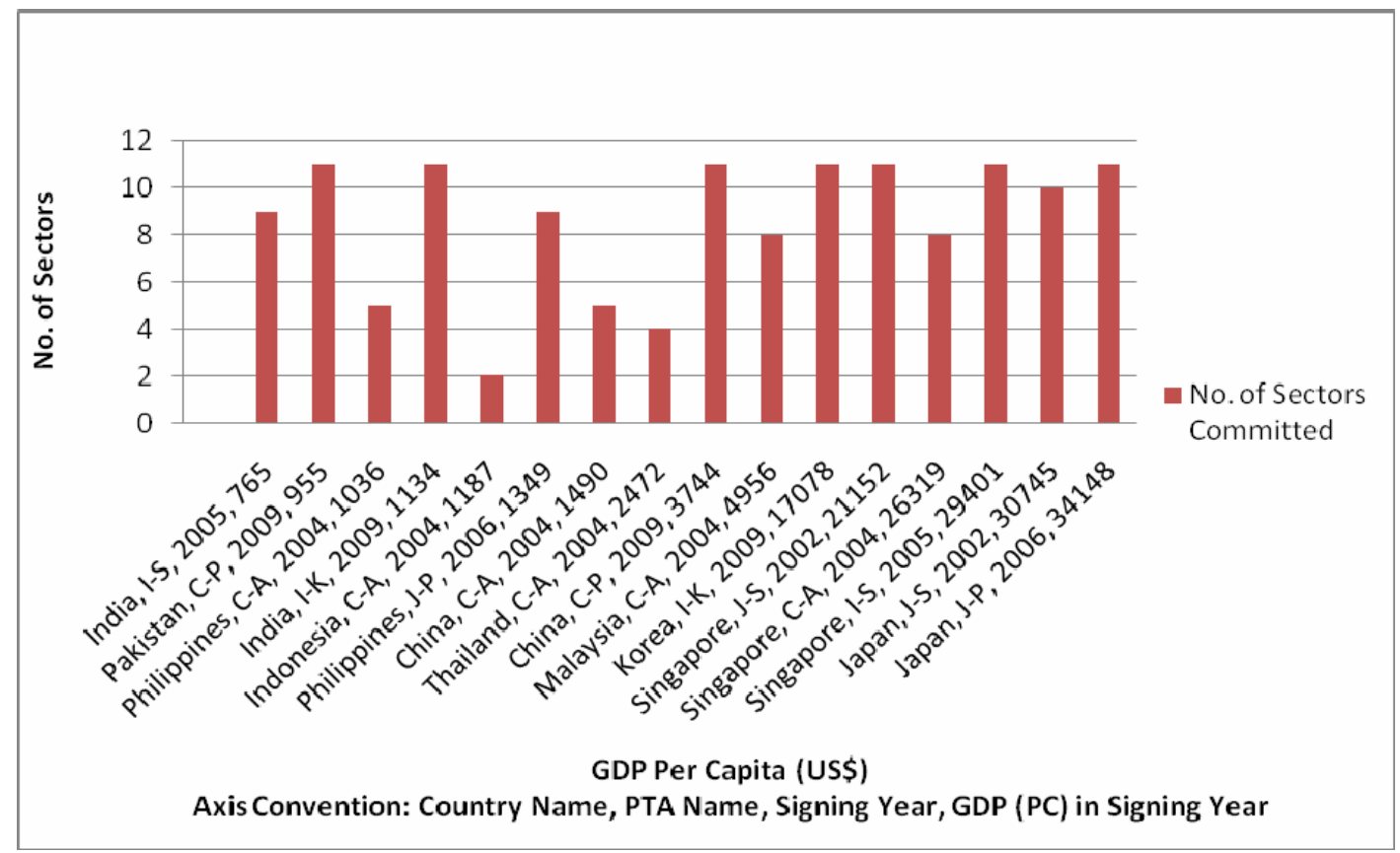

Source: Based on analysis of country's schedules of commitments under the selected PTAs and GDP per capita data from http://data.worldbank.org/indicator/NY.GDP.MKTP.CD

Figure C.4 Number of sub-sectors committed under selected PTAs and GDP per capita at time of commitment for selected countries

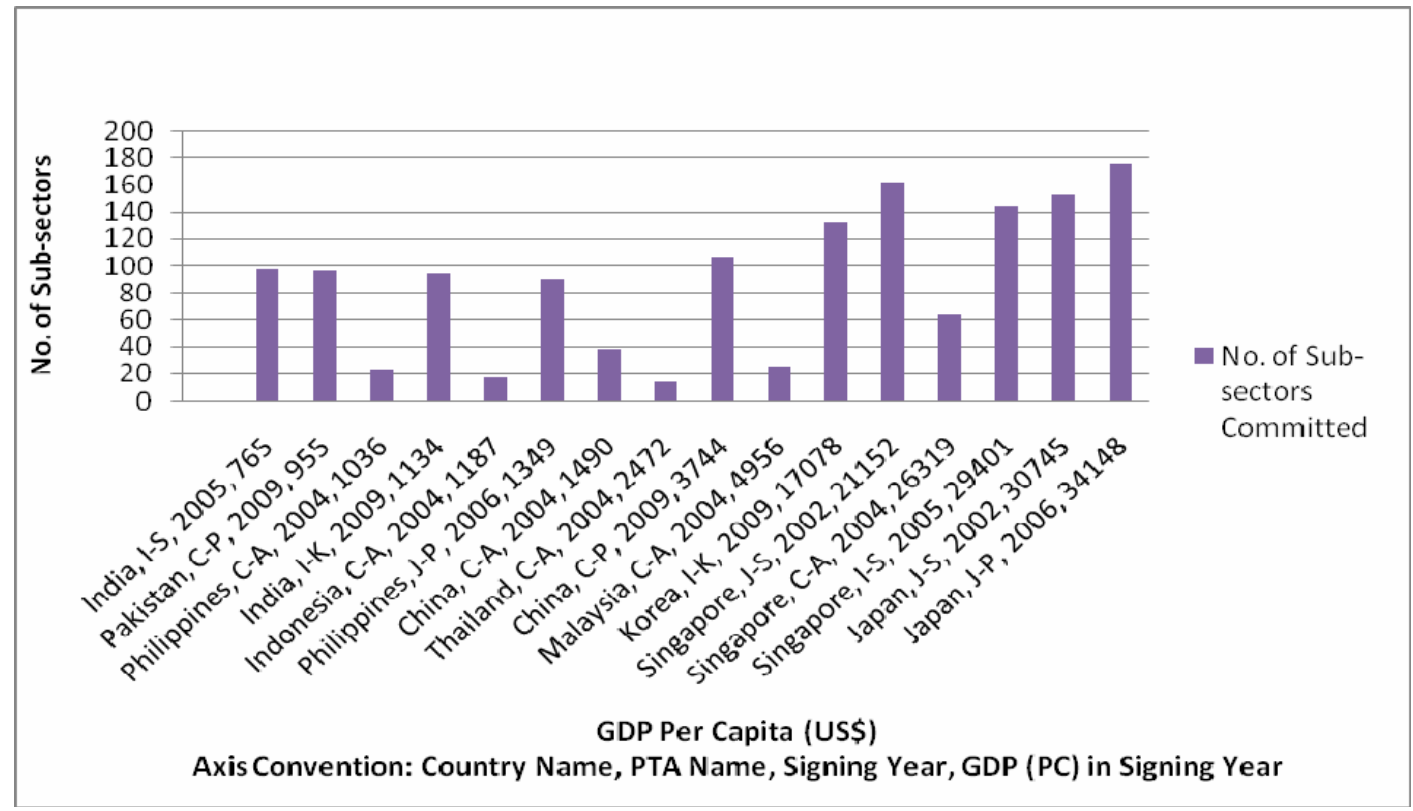

Source: Based on analysis of country's schedules of commitments under the selected PTAs and GDP per capita data from http://data.worldbank.org/indicator/NY.GDP.MKTP.CD 